Measured Solubilities and Speciations from Oversaturation Experiments of Neptunium, Plutonium, and Americium in UE-25p \#l Well Water from the Yucca Mountain Region Milestone Report 3329 - WBS1.2.3.4.1.3.1 
Edited by Jeff Skiby, Group IS-I

Photocomposition by Patrick McFarlin, Johnson Engineering, for Group IS-1

Prepared for:

Waste Minimization Program Office

Los Alamos National Laboratory

Los Alamos, New Mexico 87545

An Affirmative Action/Equal Opportunity Employer

This report was prepared as an account of work sponsored by an agency of the United States Government. Neither The Regents of the University of California the United States Government nor any agency thereof, nor any of their employees, makes any warranty, express or implied, or assumes any legal liability or responsibility for the accuracy, completeness, or usefulness of any information apparatus, product, or process disclosed, or represents that its use would not infringe privately owned rights. Reference herein to any specific commercial product, process, or service by trade name, trademark, manufacturer, or otherwise, does not necessarily constitute or imply its endorsement, recommendation, or favoring by The Regents of the University of California, the United States Government, or any agency thereof. The views and opinions of authors expressed herein do not necessarily state or reflect those of The Regents of the University of California, the United States Government, or any agency thereof. 
UC-802

Issued: April 1994

Measured Solubilities and Speciations from

Oversaturation Experiments of Neptunium, Plutonium, and Americium in UE-25p \#1 Well Water from the

Yucca Mountain Region

Milestone Report 3329 - WBS1.2.3.4.1.3.1

H. Nitsche*

K. Roberts*

T. Prussin*

A. Müller*

K. Becraft*

D. Keeney*

S. A. Carpenter*

R. C. Gatti*

*Lawrence Berkeley Laboratory, University of Califomia, Earth Sciences Division,

ICyclotron Road, Mail Stop 70A-1150, Berkeley, CA 94720.

\section{Los Alamos}

NATIONAL LABORATORY

Los Alamos, New Mexico 87545

\section{MASTER}




\section{PREFACE}

This report is the second document in a series of reports documenting experimental solubility and speciation studies of radionuclides in groundwaters from the Yucca Mountain region. The objectives and experimental concepts were discussed in detail in the first report of this series (Milestone 3010), titled "Measured Solubilities and Speciations of Neptunium, Plutonium, and Americium in a Typical Groundwater from the Yucca Mountain Region."' Sections 2, 3, and 4 of this report are, except for minor changes, identical to the respective sections of the first report. They are, however, included here to make this report a stand-alone document. 


\section{TABLE OF CONTENTS}

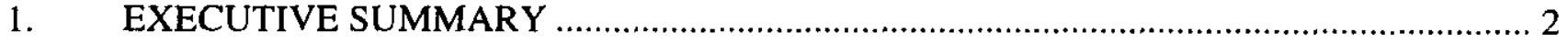

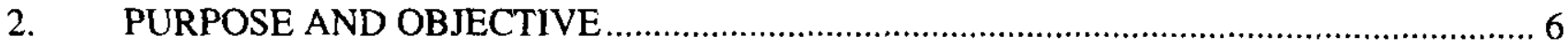

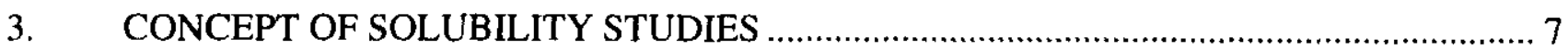

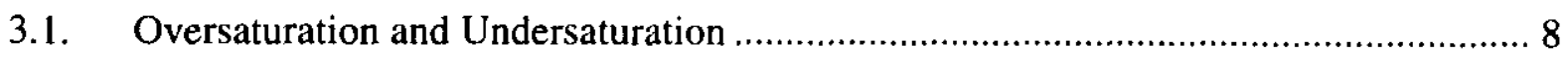

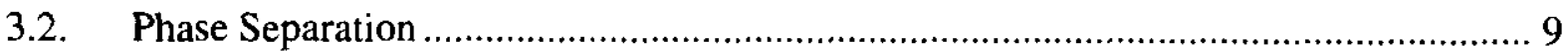

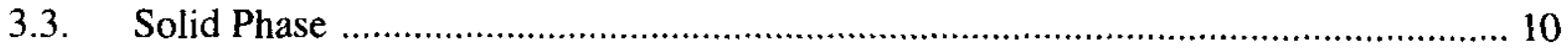

3.4. Determination of Oxidation States and Speciation ................................................ 10

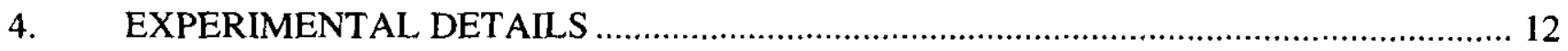

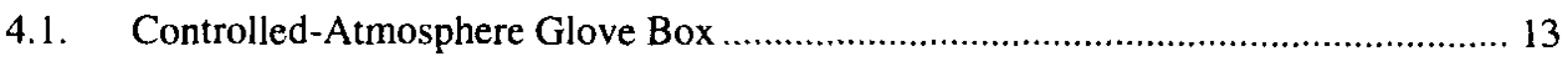

4.2. Control System for $\mathrm{pH}$ and Temperature ………............................................ 13

4.3. Pressure Control System ......................................................................... 13

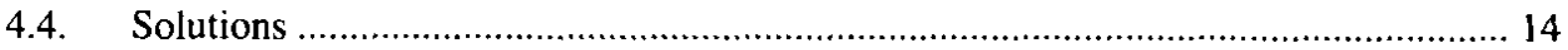

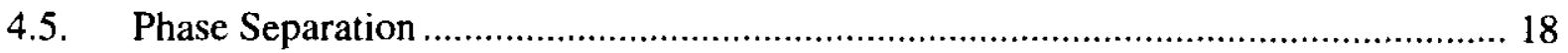

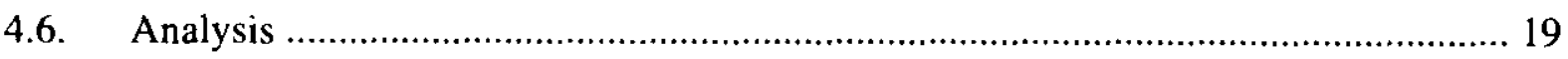

4.7. Criteria for Steady-State Concentrations ………............................................... 19

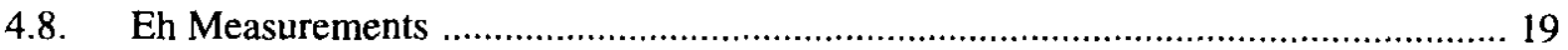

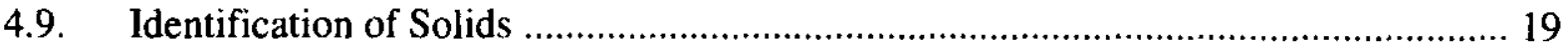

5. RESULTS AND DISCUSSION

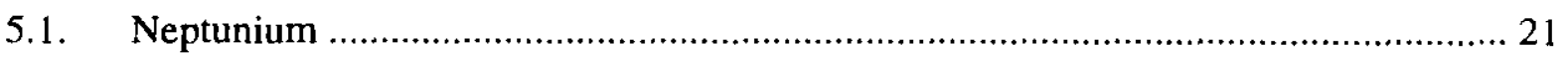

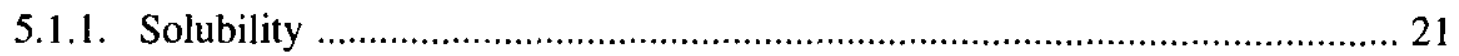

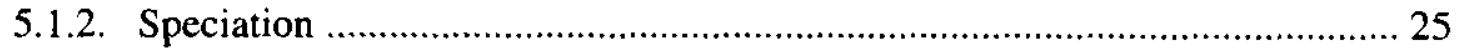

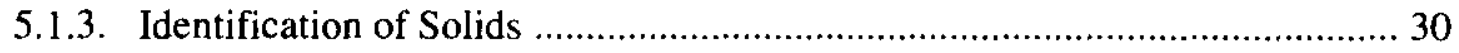

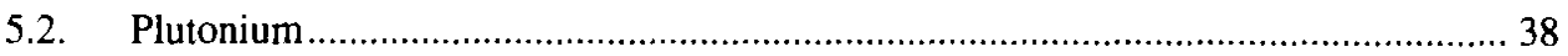

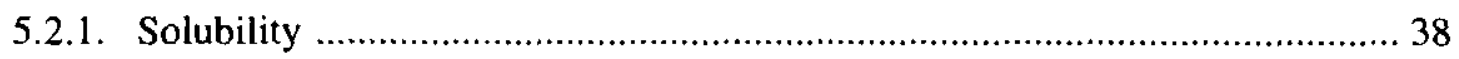

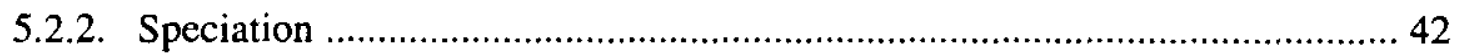

5.2.3. Identification of Solids .......................................................................... 49

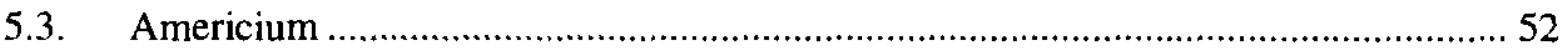

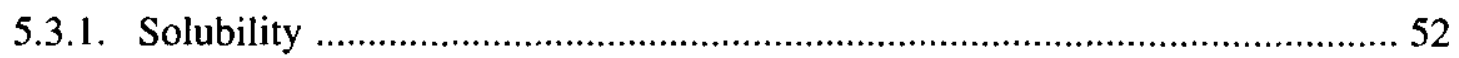

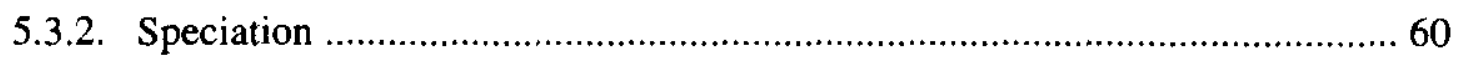

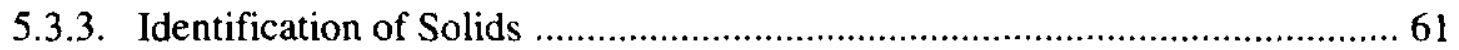

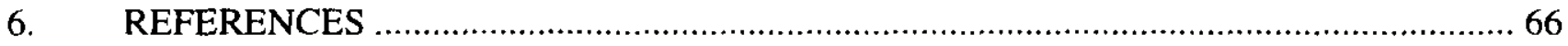

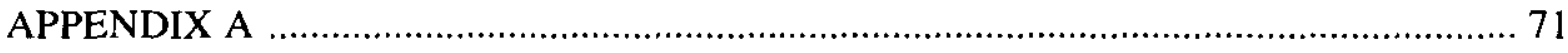

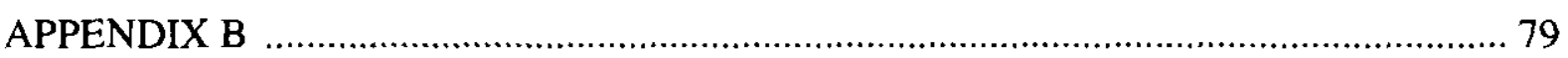

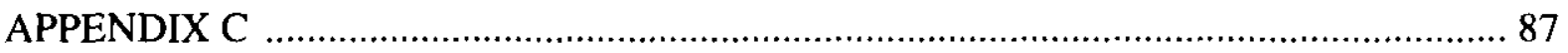




\section{LIST OF FIGURES}

Figure 1. Results of the neptunium solubility experiments in UE-25p \#1 groundwater as a function of $\mathrm{pH}$ and temperature.

Figure 2. Solution concentrations of ${ }^{237} \mathrm{~Np}$ in contact with precipitate obtained from supersaturation of UE- $25 \mathrm{p} \# 1$ groundwater at $25^{\circ} \mathrm{C}$ as a function of time. $\mathrm{pH}$ 6.0 \pm 0.1 (closed circles), $\mathrm{pH} 7.0 \pm 0.1$ (closed triangles), and $\mathrm{pH} 8.5 \pm 0.1$ (closed squares). The neptunium was added initially (day 0 ) as $\mathrm{NpO}_{2}^{+}$; initial concentrations were $4.8 \times 10^{-3} \mathrm{M}(\mathrm{pH} 6), 1.5 \times 10^{-3} \mathrm{M}(\mathrm{pH})$, and $1.4 \times 10^{-3} \mathrm{M}(\mathrm{pH} 8.5)$.

Figure 3. Solution concentrations of ${ }^{237} \mathrm{~Np}$ in contact with precipitate obtained from supersaturation of UE- $25 \mathrm{p} \# 1$ groundwater at $60^{\circ} \mathrm{C}$ as a function of time. $\mathrm{pH} 6.0$ \pm 0.1 (closed circles), $\mathrm{pH} 7.0 \pm 0.1$ (closed triangles), and $\mathrm{pH} 8.5 \pm 0.1$ (closed squares). The neptunium was added initially (day 0 ) as $\mathrm{NpO}_{2}{ }^{+}$; initial concentrations were $5.6 \times 10^{-3} \mathrm{M}(\mathrm{pH} 6), 1.5 \times 10^{-3} \mathrm{M}(\mathrm{pH} 7)$, and $1.5 \times 10^{-3} \mathrm{M}(\mathrm{pH} 8.5)$. Undersaturation experiments at $\mathrm{pH} 6.0$ (open circles), $\mathrm{pH} 7.0$ (open triangles), and $\mathrm{pH} 8.5$ (open squares) were started with precipitates obtained in the super saturation experiments at their respective $\mathrm{pH}$ values.

Figure 4. Results of $\mathrm{Np}$ filtration experiments at $25^{\circ} \mathrm{C}$ and $\mathrm{pH} 6,7$, and 8.5 conducted 100 ) days after the start of the experiments.

Figure 5. Results of $\mathrm{Np}$ filtration experiments at $60^{\circ} \mathrm{C}$ and $\mathrm{pH} 6,7$, and 8.5 conducted 87 days after the start of the experiments.

Figure 6. Near-IR absorption spectra of Np supernatant solutions at steady state formed in UE-25p \#1 groundwater at $25^{\circ} \mathrm{C}$ in $\mathrm{pH} 7.0$ : (1) at the experimental $\mathrm{pH}$ and (2) after acidification with $\mathrm{HClO}_{4}$ to $\mathrm{pH} 0$.

Figure 7. Near-IR absorption spectra of Np supernatant solutions at steady state formed in UE-25p \#1 groundwater at $60^{\circ} \mathrm{C}$ in $\mathrm{pH} 5.9:$ (1) at the experimental $\mathrm{pH}$ and (2) after acidification with $\mathrm{HClO}_{4}$ to $\mathrm{pH} 2$.

Figure 8. Near-IR absorption spectra of Np supernatant solutions at steady state formed in UE-25p \#1 groundwater at $60^{\circ} \mathrm{C}$ in $\mathrm{pH} 7.0:$ (1) at the experimental $\mathrm{pH}$; (2) after acidification with $\mathrm{HClO}_{4}$ to $\mathrm{pH} 1$. 28

Figure 9. Near-IR absorption spectra of Np supernatant solutions at steady state formed in UE-25p \#1 groundwater at $60^{\circ} \mathrm{C}$ in $\mathrm{pH} 8.5:$ (1) at the experimental $\mathrm{pH}$; (2) after acidification with $\mathrm{HClO}_{4}$ to $\mathrm{pH} 1$. 28

Figure 10. Deconvolution of the spectrum from the neptunium oversaturation experiment at $\mathrm{pH} 7$ and $25^{\circ} \mathrm{C}$ showing the two deconvoluted peaks at 980.6 and $991 \mathrm{~nm}$. 29 
Figure 11. Results of the plutonium solubility experiments in UE-25p \#1 groundwater as a function of $\mathrm{pH}$ and temperature.

Figure 12. Solution concentrations of ${ }^{239} \mathrm{Pu}$ in contact with precipitate obtained from supersaturation of UE-25p \#1 groundwater at $25^{\circ} \mathrm{C}$ as a function of time. $\mathrm{pH} 6.0$ \pm 0.1 (closed circles), $\mathrm{pH} 7.0 \pm 0.1$ (closed triangles), and $\mathrm{pH} 8.5 \pm 0.1$ (closed squares). The plutonium was added initially (day 0 ) as $\mathrm{Pu}^{4+}$; initial concentrations were $3.8 \times 10^{-4} \mathrm{M}(\mathrm{pH} 6), 3.8 \times 10^{-4} \mathrm{M}(\mathrm{pH} 7)$, and $3.8 \times 10^{-4} \mathrm{M}(\mathrm{pH} 8.5)$.

Figure 13. Solution concentrations of ${ }^{239} \mathrm{Pu}$ in contact with precipitate obtained from supersaturation of UE-25p \#1 groundwater at $60^{\circ} \mathrm{C}$ as a function of time. $\mathrm{pH} 6.0$ \pm 0.1 (closed circles), $\mathrm{pH} 7.0 \pm 0.1$ (closed triangles), and $\mathrm{pH} 8.5 \pm 0.1$ (closed squares). The plutonium was added initially (day 0 ) as $\mathrm{Pu}^{4+}$; initial concentrations were $2.2 \times 10^{-4} \mathrm{M}(\mathrm{pH} \mathrm{6}), 2.2 \times 10^{-4} \mathrm{M}(\mathrm{pH} 7)$, and $2.0 \times 10^{-4} \mathrm{M}(\mathrm{pH} 8.5)$. Undersaturation experiments at $\mathrm{pH} 6.0$ (open circles), $\mathrm{pH} 7.0$ (open triangles), and $\mathrm{pH} 8.5$ (open squares) were started with precipitates obtained in the supersaturation experiments at their respective $\mathrm{pH}$ values.

Figure 14. Results of Pu filtration experiments at $25^{\circ} \mathrm{C}$ and $\mathrm{pH} 6,7$, and 8.5 conducted 83 days after the start of the experiments.

Figure 15. Results of Pu filtration experiments at $60^{\circ} \mathrm{C}$ and $\mathrm{pH} \mathrm{6,7,} \mathrm{and} 8.5$ conducted 65 days after the start of the experiments.

Figure 16. Plutonium oxidation state distributions of the supernatant at steady state for $\mathrm{Pu}^{4+}$ solubility experiments in UE-25p \#1 groundwater at $\mathrm{pH} 6.0$ and $25^{\circ}$ and $60^{\circ} \mathrm{C}$. The solutions were filtered through $4.1 \mathrm{~nm}$ filters.

Figure 17. Plutonium oxidation state distributions of the supernatant at steady state for $\mathrm{Pu}^{4+}$ solubility experiments in UE-25p \# 1 groundwater at $\mathrm{pH} 7.0$ and $25^{\circ}$ and $60^{\circ} \mathrm{C}$. The solutions were filtered through $4.1 \mathrm{~nm}$ filters.

Figure 18. Plutonium oxidation state distributions of the supernatant at steady state for $\mathrm{Pu}^{4+}$ solubility experiments in UE-2.5p \#1 groundwater at $\mathrm{pH} 8.5$ and $25^{\circ}$ and $60^{\circ} \mathrm{C}$. The solutions were filtered through $4.1 \mathrm{~nm}$ filters.

Figure 19. Results for ${ }^{241} \mathrm{Am}^{3+} / \mathrm{Nd}^{3+}$ solubility experiments in UE-25p \#l groundwater as a function of $\mathrm{pH}$ and temperature. 53

Figure 20. Solution concentrations of ${ }^{241} \mathrm{Am} / \mathrm{Nd}$ in contact with precipitate obtained from supersaturation of UE-25p \# 1 groundwater at $25^{\circ} \mathrm{C}$ as a function of time. $\mathrm{pH} 6.0$ \pm 0.1 (closed circles), $\mathrm{pH} 7.0 \pm 0.1$ (closed triangles), and $\mathrm{pH} 8.5 \pm 0.1$ (closed squares). The americium/neodymium was added initially (day 0 ) as ${ }^{24 !} \mathrm{Am}^{3+1}$ $\mathrm{Nd}^{3+}$. Initial $\left({ }^{241} \mathrm{Am}^{3+}+\mathrm{Nd}^{3+}\right)$ concentrations were $1.9 \times 10^{-4} \mathrm{M}(\mathrm{pH} 6), 1.9 \times$ $10^{-4} \mathrm{M}(\mathrm{pH} 7)$, and $1.9 \times 10^{-4} \mathrm{M}(\mathrm{pH} 8.5)$. 54 
Figure 21. Solution concentrations of ${ }^{241} \mathrm{Am} / \mathrm{Nd}$ in contact with precipitate obtained from supersaturation of UE-25p \#1 groundwater at $60^{\circ} \mathrm{C}$ as a function of time. $\mathrm{pH} 6.0$ \pm 0.1 (closed circles), $\mathrm{pH} 7.0 \pm 0.1$ (closed triangles), and $\mathrm{pH} 8.5 \pm 0.1$ (closed squares). The americium/neodymium was added initially (day 0 ) as ${ }^{241} \mathrm{Am}^{3+1}$ $\mathrm{Nd}^{3+}$; initial $\left({ }^{241} \mathrm{Am}^{3+}+\mathrm{Nd}^{3+}\right)$ concentrations were $2.3 \times 10^{-4} \mathrm{M}(\mathrm{pH} 6), 2.3 \times 10^{-}$ ${ }^{4} \mathrm{M}(\mathrm{pH} 7)$, and $2.3 \times 10^{-4} \mathrm{M}(\mathrm{pH} \mathrm{8.5)}$. Undersaturation experiments at $\mathrm{pH} 6.0$ (open circles), pH 7.0 (open triangles), and $\mathrm{pH} 8.5$ (open squares) were started with precipitates obtained in the supersaturation experiments at their respective $\mathrm{pH}$ values.

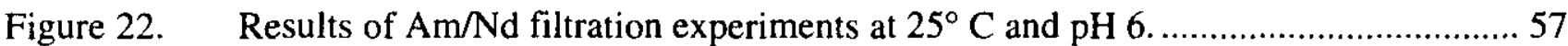

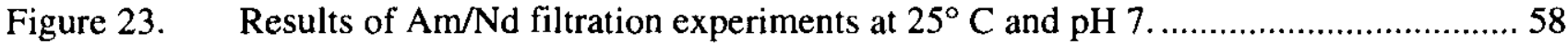

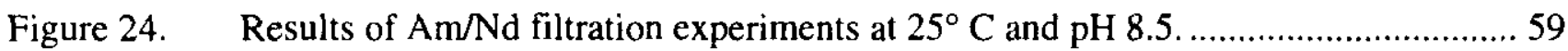

Figure 25. Results of initial Am/Nd filtration experiments at $60^{\circ} \mathrm{C}$ and $\mathrm{pH} \mathrm{6,7}$, and 8.5 conducted 1 day after the start of the experiments. 


\section{LIST OF TABLES}

Table I. Summary of results for solubility experiments on neptunium in UE-25p \#1 groundwater at $\mathrm{pH} 6,7$, and 8.5 and at $25^{\circ}$ and $60^{\circ} \mathrm{C}$.

Table II. Summary of results for solubility experiments on plutonium in UE-25p \#1 groundwater at $\mathrm{pH} 6,7$, and 8.5 and at $25^{\circ}$ and $60^{\circ} \mathrm{C}$.

Table III. Summary of results for solubility experiments on americium/neodymium in UE-25p \#1 groundwater at $\mathrm{pH} 6,7$, and 8.5 and at $25^{\circ}$ and $60^{\circ} \mathrm{C}$.

Table IV. UE-25p \#1 Water Composition ${ }^{4}$ 12

Table V. Concentrations (in percent) of carbon dioxide gas in argon to maintain a total dissolved carbonate concentration of $1.531 \times 10^{-2} \mathrm{M}$ in UE-25p \#1 water at different $\mathrm{pH}$ and temperatures together with the values for Henry's constant and the dissociation constants for carbonic acid used to determine the $\mathrm{pCO}_{2}$ values.

Table VI. Comparison of steady-state solution concentrations and Eh for neptunium in UE-25p \#l water at $25^{\circ}$ and $60^{\circ} \mathrm{C}$.

Table VII. Comparison of extent of carbonate complexation for steady state solutions of neptunium in UE-25p \#1 groundwater at $25^{\circ}$ and $60^{\circ} \mathrm{C}$.

Table VIII. X-ray powder diffraction patterns of neptunium solid phases in UE-25p \#1 groundwater at $25^{\circ}$ and $60^{\circ} \mathrm{C}$ and $\mathrm{pH} 5.9$.

Table IX. X-ray powder diffraction patterns of neptunium solid phases in UE-25p \#1 groundwater at $25^{\circ}$ and $60^{\circ} \mathrm{C}$ and $\mathrm{pH} 7.0$.

Table X. X-ray powder diffraction patterns of neptunium solid phases in UE-25p \#1 groundwater at $25^{\circ}$ and $60^{\circ} \mathrm{C}$ and $\mathrm{pH} 8.5$.

Table XI. X-ray powder diffraction patterns of neptunium solid phases in UE-25p \#1 groundwater at $25^{\circ} \mathrm{C}, \mathrm{pH} 5.9, \mathrm{pH} 7.0$, and $\mathrm{pH} 8.5$ compared with the pattern of $\mathrm{Na}_{0.6} \mathrm{NpO}_{2}\left(\mathrm{CO}_{3}\right)_{0.8} \cdot 2.5 \mathrm{H}_{2} \mathrm{O} .{ }^{30}$

Table XII. X-ray powder diffraction patterns of neptunium solid phases in UE-25p \#1 groundwater at $60^{\circ} \mathrm{C}, \mathrm{pH} 5.9, \mathrm{pH} 7.0$, and $\mathrm{pH} 8.5$ compared with the pattern of $\mathrm{Na}_{0.6} \mathrm{NpO}_{2}\left(\mathrm{CO}_{3}\right)_{0.8} \cdot 2.5 \mathrm{H}_{2} \mathrm{O} .{ }^{30}$ 36

Table XIII. X-ray powder diffraction patterns of neptunium solid phases in UE-25p \#1 groundwater at $60^{\circ}, \mathrm{pH} 5.9, \mathrm{pH} 7.0$, and $\mathrm{pH} 8.5$ compared with the pattern of $\mathrm{Na}_{3} \mathrm{NpO}_{2}\left(\mathrm{CO}_{3}\right)_{2} \cdot \mathrm{nH}_{2} \mathrm{O} .{ }^{31}$ 
Table XIV. Comparison of steady-state solution concentrations and Eh for plutonium in $\mathrm{UE}-25 \mathrm{p} \# 1$ water at $25^{\circ}$ and $60^{\circ} \mathrm{C}$.

Table XV. Methods Used for Determining Plutonium Oxidation States in Solution at $25^{\circ} \mathrm{C}$.

Table XVI. Methods Used for Determining Plutonium Oxidation States in Solution at $60^{\circ} \mathrm{C}$.

Table XVII. Plutonium oxidation state determinations in UE-25p \#1 at pH values 6, 7, and 8.5 and $25^{\circ}$ and $60^{\circ} \mathrm{C}$.

Table XVIII. X-ray powder diffraction patterns of plutonium solid phases in UE-25p \#1 groundwater at $25^{\circ}$ and $\mathrm{pH} 5.9, \mathrm{pH} 7.0$, and $\mathrm{pH} 8.5$.

Table XIX. X-ray powder diffraction patterns of plutonium solid phases in UE-25p \#1 groundwater at $25^{\circ} \mathrm{C}$ and $\mathrm{pH} 8.5$ compared with the pattern of $\mathrm{PuO}_{2}{ }^{36}$

Table XX. X-ray powder diffraction patterns of plutonium solid phases in UE-25p \#1 groundwater at $60^{\circ} \mathrm{C}$ and $\mathrm{pH} 7.0$ and $\mathrm{pH} 8.5$.

Table XXI. Comparison of steady-state solution concentrations and Eh for americium/ neodymium in UE-25p \#1 water at $25^{\circ}$ and $60^{\circ} \mathrm{C}$.

Table XXII. X-ray powder diffraction patterns of $\mathrm{Nd} / 241 \mathrm{Am}$ solid phases in UE-25p \# 1 groundwater at $25^{\circ}$ and $60^{\circ} \mathrm{C}$ and $\mathrm{pH} 6,7$, and 8.5 .

Table XXIII. X-ray powder diffraction patterns of $\mathrm{Nd} /{ }^{241} \mathrm{Am}$ solid phases in UE-25p \#1 groundwater at $25^{\circ} \mathrm{C}$ and $\mathrm{pH} 6,7$, and 8.5 compared with reference patterns of: $1 . \mathrm{Nd}_{2}\left(\mathrm{CO}_{3}\right)_{3} \cdot 2 \mathrm{H}_{2} \mathrm{O}, 2$. hexagonal $\mathrm{NdOHCO}_{3}$, and 3. orthorhombic $\mathrm{NdOHCO}_{3},{ }^{40,42,43}$

Table XXIV. X-ray powder diffraction patterns of $\mathrm{Nd} /{ }^{241} \mathrm{Am}$ solid phases in UE-25p\#1 groundwater at $60^{\circ} \mathrm{C}$ and $\mathrm{pH} 6,7$, and 8.5 compared with reference patterns of: $1 . \mathrm{Nd}_{2}\left(\mathrm{CO}_{3}\right)_{3} \cdot 2 \mathrm{H}_{2} \mathrm{O}, 2$. hexagonal $\mathrm{NdOHCO}_{3}$, and 3. orthorhombic $\mathrm{NdOHCO}_{3},{ }^{40,42,43}$ 


\title{
MEASURED SOLUBILITIES AND SPECIATIONS FROM OVERSATURATION EXPERIMENTS OF NEPTUNIUM, PLUTONIUM, AND AMERICIUM IN UE-25P \#1 WELL WATER FROM THE YUCCA MOUNTAIN REGION MILESTONE REPORT 3329 - WBS1.2.3.4.1.3.1
}

\author{
by \\ H. Nitsche, K. Roberts, T. Prussin, A. Müller, K. Becraft, D. Keeney, \\ S. A. Carpenter, and R. C. Gatti
}

\begin{abstract}
Solubility and speciation are important in understanding aqueous radionuclide transport through the geosphere. They define the source term for transport retardation processes such as sorption and colloid formation. Solubility and speciation data are useful in verifying the validity of geochemical codes that are a part of predictive transport models. Results are presented from solubility and speciation experiments of ${ }^{237} \mathrm{NpO}_{2}{ }^{+},{ }^{239} \mathrm{Pu}^{4+}$, and ${ }^{241} \mathrm{Am}^{3+} / \mathrm{Nd}^{3+}$ in a modified UE-25p \#1 groundwater (from the Yucca Mountain region, Nevada, which is being investigated as a potential high-level nuclear waste disposal site) at two different temperatures $\left(25^{\circ}\right.$ and $\left.60^{\circ} \mathrm{C}\right)$ and three $\mathrm{pH}$ values $(6.0,7.0,8.5)$. The solubility-controlling steady-state solids were identified and the speciation and/or oxidation states present in the supernatant solutions were determined. The neptunium solubility decreased with increasing temperature and $\mathrm{pH}$. Plutonium concentrations significantly decreased with increasing temperature at $\mathrm{pH} 6$ and 7. The concentration at $\mathrm{pH} 8.5$ hardly decreased at all with increasing temperature. At both temperatures the concentrations were highest at $\mathrm{pH} 8.5$, lowest at $\mathrm{pH} \mathrm{7,} \mathrm{and} \mathrm{in} \mathrm{between} \mathrm{at} \mathrm{pH} 6$. For the americium/neodymium solutions, the solubility decreased significantly with increasing temperature and increased somewhat with increasing $\mathrm{pH}$.
\end{abstract}




\section{EXECUTIVE SUMMARY}

We studied the solubilities of neptunium, plutonium, and americium in a modified UE-25p \#1 groundwater from the Yucca Mountain region (Nevada) at two temperatures and three hydrogen concentrations. They are $25^{\circ}$ and $60^{\circ} \mathrm{C}$ and pH 6, 7, and 8.5. Tables I, II, and III summarize the results for neptunium, plutonium, and americium, respectively. The nuclides were added to UE-25p \#1 groundwater from oversaturation at the beginning of each experiment as ${ }^{237} \mathrm{NpO}_{2}{ }^{+}{ }^{239} \mathrm{Pu}^{4+}$, and $\mathrm{Nd}^{3+}$

with tracer ${ }^{241} \mathrm{Am}^{3+}$ added to facilitate nuclear counting. Because we maintained constant $\mathrm{pH}$ values of 6,7 , and 8.5 during the course of the experiments, the final solutions were closer to $0.1 \mathrm{M}$ in total ionic strength with the primary constituents being sodium and perchlorate. The steady-state solids formed in the experiments may not represent the thermodynamically most stable solids with the lowest possible solubilities, but metastable solids having higher solubilities than the thermodynamically defined solids. Because the results listed herein are from oversatuation experiments only, we cannot assume that equilibrium conditions were reached; however, this issue will be addressed in a forthcoming paper that compares undersaturation results with these oversaturation results.

The neptunium solubility decreased with increasing $\mathrm{pH}$ and with increasing temperature. The soluble neptunium did not change oxidation state at steady state. The pentavalent neptunium was increasingly complexed by carbonate with increasing $\mathrm{pH}$. The steady-state solids were crystalline sodium neptunium carbonate hydrates with varying stoichiometry.

Plutonium concentrations significantly decreased with increasing temperature at $\mathrm{pH} 6$ and 7 . The concentration at $\mathrm{pH} 8.5$ hardly decreased at all with increasing temperature. At both temperatures the concentrations were highest at $\mathrm{pH} 8.5$, lowest at $\mathrm{pH} 7$, and in between at $\mathrm{pH}$. At $25^{\circ} \mathrm{C}, \mathrm{Pu}(\mathrm{V})$ and $\mathrm{Pu}(\mathrm{IV})$ were the dominant oxidation states in the supernatant solution; as the amount of Pu(IV) increased with $\mathrm{pH}$, the amount of $\mathrm{Pu}(\mathrm{V})$ decreased. At $60^{\circ} \mathrm{C}$, the dominant oxidation state was $\mathrm{Pu}(\mathrm{VI})$. The species responsible for this oxidation are unknown. At $25^{\circ} \mathrm{C}$, the solubility-controlling solids at $\mathrm{pH} 6$ and 7 were amorphous with some crystalline component. They contained mainly $\mathrm{Pu}(\mathrm{IV})$ polymer. The solubilitycontrolling solid at $\mathrm{pH} 8.5$ was $\mathrm{PuO}_{2}$. At $60^{\circ} \mathrm{C}$, the solubility-controlling solids at $\mathrm{pH} 6$ and 7 were amorphous and contained $\mathrm{Pu}(\mathrm{IV})$ polymer. The solid produced at $\mathrm{pH} 8.5$ and $60^{\circ} \mathrm{C}$ is crystalline but unidentified.

For the americium/neodymium solutions, the solubility decreased significantly with increasing temperature and increased somewhat with increasing $\mathrm{pH}$. The oxidation state in the supernatant of the americium/neodymium solutions remained in the trivalent state. The americium/neodymium solubility experiments in UE-25p \#1 at $\mathrm{pH} 6$ have produced hexagonal $\mathrm{NdOHCO}_{3}$ at $25^{\circ} \mathrm{C}$ and possibly a mixture of $\mathrm{Nd}_{2}\left(\mathrm{CO}_{3}\right)_{3} \cdot 2 \mathrm{H}_{2} \mathrm{O}$ and hexagonal $\mathrm{NdOHCO}_{3}$ at $60^{\circ} \mathrm{C}$; whereas, experiments at $\mathrm{pH} 7$ and 8.5 produced mixtures of orthorhombic $\mathrm{NdOHCO}_{3}$ and $\mathrm{Nd}_{2}\left(\mathrm{CO}_{3}\right)_{3} \cdot 2 \mathrm{H}_{2} \mathrm{O}$ at both $25^{\circ}$ and $60^{\circ} \mathrm{C}$. 
Table I. Summary of results for solubility experiments on neptunium in UE-25p \# 1 groundwater at $\mathrm{pH} 6,7$, and 8.5 and at $25^{\circ}$ and $60^{\circ} \mathrm{C}$.

\begin{tabular}{|c|c|c|c|c|}
\cline { 2 - 5 } \multicolumn{1}{c|}{} & \multicolumn{2}{|c|}{$\begin{array}{c}\text { Steady-State } \\
\text { Concentration (M) }\end{array}$} & \multicolumn{2}{c|}{$\begin{array}{c}\text { Oxidation State in } \\
\text { Supernatant Solution (\%) }\end{array}$} \\
\cline { 2 - 5 } & $25^{\circ} \mathrm{C}$ & $60^{\circ} \mathrm{C}$ & $25^{\circ} \mathrm{C}$ & $60^{\circ} \mathrm{C}$ \\
\hline $\mathrm{pH} 6$ & $(2.9 \pm 0.6) \times 10^{-3}$ & $(2.5 \pm 0.2) \times 10^{-3}$ & $\begin{array}{c}\mathrm{V}: 100 \% \\
\text { uncomplexed }\end{array}$ & uncomplexed \\
\hline $\mathrm{pH} 7$ & $(4.7 \pm 1.1) \times 10^{-5}$ & $(3.4 \pm 1.0) \times 10^{-5}$ & $\begin{array}{c}\mathrm{V}: 100 \% \\
\mathrm{VH} 8.100 \%\end{array}$ & $10 \%$ carbonate complexed \\
\hline $\mathrm{pH} 8.5$ & $(7.0 \pm 0.6) \times 10^{-6}$ & $(2.7 \pm 0.1) \times 10^{-5}$ & (Below Detection Limit) & $100 \%$ carbonate complexed \\
\hline
\end{tabular}

\begin{tabular}{|c|c|c|c|c|}
\hline & \multicolumn{2}{|c|}{ Eh $(\mathrm{mV})$ vs. NHE } & \multicolumn{2}{|c|}{ Solid Phase } \\
\hline & $25^{\circ} \mathrm{C}$ & $60^{\circ} \mathrm{C}$ & $25^{\circ} \mathrm{C}$ & $60^{\circ} \mathrm{C}$ \\
\hline $\mathrm{pH} 6$ & $(877 \pm 15)$ & $(414 \pm 15)$ & $\begin{array}{l}\text { Sodium Neptunyl(V) } \\
\text { Carbonate Hydrates }\end{array}$ & $\begin{array}{c}\text { Sodium Neptunyl(V) } \\
\text { Carbonate Hydrates }\end{array}$ \\
\hline $\mathrm{pH} 7$ & $(438 \pm 15)$ & $(367 \pm 15)$ & $\begin{array}{l}\text { Sodium Neptunyl(V) } \\
\text { Carbonate Hydrates }\end{array}$ & $\begin{array}{c}\text { Sodium Neptunyl(V) } \\
\text { Carbonate Hydrates }\end{array}$ \\
\hline $\mathrm{pH} 8.5$ & $(259 \pm 15)$ & $(212 \pm 15)$ & $\begin{array}{l}\text { Sodium Neptunyl(V) } \\
\text { Carbonate Hydrates }\end{array}$ & $\begin{array}{c}\text { Sodium Neptunyl(V) } \\
\text { Carbonate Hydrates }\end{array}$ \\
\hline
\end{tabular}


Table II. Summary of results for solubility experiments on plutonium in UE-25p \#1 groundwater at $\mathrm{pH} 6,7$, and 8.5 and at $25^{\circ}$ and $60^{\circ} \mathrm{C}$.

\begin{tabular}{|c|c|c|c|c|c|c|}
\hline & \multicolumn{2}{|c|}{$\begin{array}{c}\text { Steady-State } \\
\text { Concentration (M) }\end{array}$} & \multicolumn{4}{|c|}{$\begin{array}{c}\text { Oxidation State in } \\
\text { Supernatant Solution }(\%)\end{array}$} \\
\hline & $25^{\circ} \mathrm{C}$ & $60^{\circ} \mathrm{C}$ & \multicolumn{2}{|c|}{$25^{\circ} \mathrm{C}$} & \multicolumn{2}{|c|}{$60^{\circ} \mathrm{C}$} \\
\hline $\mathrm{pH} 6$ & $(8.3 \pm 0.4) \times 10^{-7}$ & $(8.9 \pm 1.4) \times 10^{-8}$ & $\begin{array}{l}\text { III + Poly.: } \\
\text { IV : } \\
\text { V : } \\
\text { VI : }\end{array}$ & $\begin{array}{c}(3 \pm 1) \\
(9 \pm 1) \\
(85 \pm 7) \\
(3 \pm 3)\end{array}$ & $\begin{array}{l}\text { III + Poly. : } \\
\text { IV : } \\
\text { V : } \\
\text { VI : }\end{array}$ & $\begin{array}{c}(1 \pm 1) \\
(1 \pm 1) \\
(4 \pm 1) \\
(94 \pm 11)\end{array}$ \\
\hline $\mathrm{pH} 7$ & $(4.5 \pm 0.4) \times 10^{-7}$ & $(9.1 \pm 1.2) \times 10^{-8}$ & $\begin{array}{l}\text { III + Poly. : } \\
\text { IV : } \\
\text { V : } \\
\text { VI : }\end{array}$ & $\begin{array}{c}(2 \pm 1) \\
(12 \pm 1) \\
(78 \pm 7) \\
(9 \pm 4)\end{array}$ & $\begin{array}{l}\text { III + Poly, : } \\
\text { IV : } \\
\text { V : } \\
\text { VI : }\end{array}$ & $\begin{array}{c}(2 \pm 1) \\
(1 \pm 1) \\
(5 \pm 1) \\
(93 \pm 11)\end{array}$ \\
\hline $\mathrm{pH} 8.5$ & $(1.0 \pm 0.1) \times 10^{-6}$ & $(9.3 \pm 6.0) \times 10^{-7}$ & $\begin{array}{l}\text { III + Poly.: } \\
\text { IV : } \\
\text { V : } \\
\text { VI : }\end{array}$ & $\begin{array}{c}(3 \pm 1) \\
(31 \pm 1) \\
(64 \pm 6) \\
(2 \pm 1)\end{array}$ & $\begin{array}{l}\text { III + Poly.: } \\
\text { IV : } \\
\text { V : } \\
\text { VI : }\end{array}$ & $\begin{array}{c}(5 \pm 2) \\
(10 \pm 1) \\
(0) \\
(86 \pm 12)\end{array}$ \\
\hline
\end{tabular}

\begin{tabular}{|c|c|c|c|c|}
\cline { 2 - 5 } \multicolumn{1}{c|}{} & \multicolumn{2}{c|}{ Eh (mV) vs. NHE } & \multicolumn{2}{c|}{ Solid Phase } \\
\cline { 2 - 5 } & $25^{\circ} \mathrm{C}$ & $60^{\circ} \mathrm{C}$ & $25^{\circ} \mathrm{C}$ & $60^{\circ} \mathrm{C}$ \\
\hline $\mathrm{pH} 6$ & $(348 \pm 15)$ & $(326 \pm 15)$ & $\begin{array}{c}\text { Amorphous } \\
\text { Pu(IV) polymer }\end{array}$ & $\begin{array}{c}\text { Amorphous } \\
\text { Pu(IV) polymer }\end{array}$ \\
\hline pH 7 & $(282 \pm 15)$ & $(334 \pm 15)$ & $\begin{array}{c}\text { Amorphouss } \\
\text { Pu(IV) polymer }\end{array}$ & $\begin{array}{c}\text { Amorphous } \\
\text { Pu(IV) polymer }\end{array}$ \\
\hline pH 8.5 & $(273 \pm 15)$ & $(231 \pm 15)$ & $\begin{array}{c}\text { Crystalline } \\
\text { Unidentified }\end{array}$ \\
\hline
\end{tabular}


Table III. Summary of results for solubility experiments on americium/neodymium in UE-25p \#1 groundwater at $\mathrm{pH} 6,7$, and 8.5 and at $25^{\circ}$ and $60^{\circ} \mathrm{C}$.

\begin{tabular}{|c|c|c|c|c|}
\cline { 2 - 5 } \multicolumn{1}{c|}{} & \multicolumn{2}{c|}{$\begin{array}{c}\text { Steady-State } \\
\text { Concentration (M) }\end{array}$} & \multicolumn{2}{c|}{$\begin{array}{c}\text { Oxidation State in } \\
\text { Supernatant Solution (\%) }\end{array}$} \\
\cline { 2 - 5 } & $25^{\circ} \mathrm{C}$ & $60^{\circ} \mathrm{C}$ & $25^{\circ} \mathrm{C}$ & $60^{\circ} \mathrm{C}$ \\
\hline $\mathrm{pH} 6$ & $(3.1 \pm 1.1) \times 10^{-7}$ & $(2.7 \pm 0.4) \times 10^{-9}$ & III : $100 \%$ & III : $100 \%$ \\
\hline $\mathrm{pH} 7$ & $(3.2 \pm 1.6) \times 10^{-7}$ & $(7.1 \pm 0.5) \times 10^{-10}$ & III : $100 \%$ & Not Available. \\
\hline $\mathrm{pH} 8.5$ & $(3.1 \pm 0.8) \times 10^{-6}$ & $(7.8 \pm 4.3) \times 10^{-9}$ & III : $100 \%$ & III : $100 \%$ \\
\hline
\end{tabular}

\begin{tabular}{|c|c|c|c|c|}
\hline & \multicolumn{2}{|c|}{ Eh $(\mathrm{mV})$ vs. NHE } & \multicolumn{2}{|c|}{ Solid Phase } \\
\hline & $25^{\circ} \mathrm{C}$ & $60^{\circ} \mathrm{C}$ & $25^{\circ} \mathrm{C}$ & $60^{\circ} \mathrm{C}$ \\
\hline $\mathrm{pH} 6$ & $(376 \pm 15)$ & $(370 \pm 15)$ & hexagonal $\mathrm{AmOHCO}_{3}$ & $\begin{array}{l}(\mathrm{Am})_{2}\left(\mathrm{CO}_{3}\right)_{3} \cdot 2 \mathrm{H}_{2} \mathrm{O} \\
\text { and } \\
\text { hexagonal } \mathrm{AmOHCO} \mathrm{OHCO}_{3}\end{array}$ \\
\hline $\mathrm{pH} 7$ & $(358 \pm 15)$ & Not Available. & $\begin{array}{c}(\mathrm{Am})_{2}\left(\mathrm{CO}_{3}\right)_{3} \cdot 2 \mathrm{H}_{2} \mathrm{O} \\
\text { and } \\
\text { orthorhombic AmOHCO }\end{array}$ & $\begin{array}{c}(\mathrm{Am})_{2}\left(\mathrm{CO}_{3}\right)_{3} \cdot 2 \mathrm{H}_{2} \mathrm{O} \\
\text { and } \\
\text { orthorhombic } \mathrm{AmOHCO}_{3}\end{array}$ \\
\hline pH 8.5 & $(111 \pm 15)$ & $(220 \pm 15)$ & $\begin{array}{l}(\mathrm{Am})_{2}\left(\mathrm{CO}_{3}\right)_{3} \cdot 2 \mathrm{H}_{2} \mathrm{O} \\
\text { and } \\
\text { orthorhombic } \mathrm{AmOHCO}\end{array}$ & $\begin{array}{c}(\mathrm{Am})_{2}\left(\mathrm{CO}_{3}\right)_{3} \cdot 2 \mathrm{H}_{2} \mathrm{O} \\
\text { and } \\
\text { orthorhombic } \mathrm{AmOHCO}\end{array}$ \\
\hline
\end{tabular}




\section{PURPOSE AND OBJECTIVE}

Yucca Mountain, Nevada, was identified for site characterization as a site for a potential repository of high-level nuclear waste. As a worst case scenario, intrusion of water into the repository must be considered for risk assessment. Water moving through the emplacement area towards the accessible environment can transport radionuclides in two ways: either as dissolved species in the water or as particulate material by the water. The Yucca Mountain Site Characterization Plan (SCP) requires "Studies to Provide the Information Required on Radionuclide Retardation by Precipitation Processes along Flow Paths to the Accessible Environment" before licensing and construction of the repository. ${ }^{2}$ The purpose of this study is to supply data for calculating radionuclide transport along potential transport pathways from the repository to the accessible environment. Data derived from solubility studies are important for validating geochemical codes that are part of predictive radionuclide transport models. Such codes should be capable of predicting the results of solubility experiments, where the measured solubility is the sum of the equivalent concentrations of all of the species in equilibrium with a specified solid. Furthermore, agreement between geochemical calculations and experimental results can validate the thermodynamic data base used with the modeling calculation.

To predict behavior at higher temperatures, data bases used for modeling calculations must contain data on thermodynamic functions at elevated temperatures. To date, many of these data are unavailable and are therefore estimated by extrapolation from lower temperature data. Agreement between modeling calculations and experimental results would also validate such estimates, whereas significant discrepancies would identify the need for data base improvement. Improvements can be made by filling the gaps with basic experimental data.

In addition, experimental solubility data also provide the source terms or the starting concentrations for experimental sorption studies. To be valid, sorption studies should be conducted at or below the solubility limit because only soluble species can be transported and participate in the sorption process.

In selecting these experiments, we have considered the generic U.S. Nuclear Regulatory Commission (NRC) technical position titled "Determination of Radionuclide Solubility in Groundwater for Assessment of High-Level Waste Isolation." 3 This technical position served as guidance for our experiments to determine radionuclide solubility. It requires that if radionuclide solubility is used as a factor in limiting radionuclide release, experiments must be designed to determine solubility under sitespecific conditions.

Radionuclide concentrations in water passing through the emplacement area can be limited by two mechanisms: low dissolution rates of the solid waste form or solubilities of individual radionuclides. If solid waste dissolution rates are low enough, it may not be necessary to depend on solubilities to limit radionuclide concentrations. However, the solid waste forms have not yet been determined, and therefore the dissolution rates of the solid waste are unknown. Determination of radionuclide solubility limits provides an upper bound on radionuclide concentrations in solution and provides a basis for "extrapolation to long-term behavior." The rate of groundwater flow through the waste is expected to 
be sufficiently slow to permit saturation of water with radionuclides. Dissolution limited by saturation will provide maximum concentration limits. Therefore, an assessment of radionuclide release rates using a saturation-limited dissolution model represents the most conservative approach possible.

As radionuclides are transported along flow paths to the accessible environment, changing conditions of the water ( $\mathrm{pH}, \mathrm{Eh}$, and concentrations of complexing species) can alter solubilities. Decreases in solubility can decrease radionuclide concentrations. A knowledge of radionuclide solubilities under the conditions along possible flow paths is necessary to assess this scenario. Solubility studies are very time-consuming because long times are often needed to reach equilibrium. Because we cannot investigate every possible solubility scenario, we selected $\mathrm{pH}$ and temperature values to bracket the expected range of conditions by choosing parameters that represent lower and upper limits.

Neptunium, plutonium, and americium are expected to be sparingly soluble with solubilitylimited dissolution. Water samples with compositions that bracket the range of waters expected in the vicinity of Yucca Mountain were chosen for solubility measurements. ${ }^{4}$ These samples come from two sources. Water from Well $\mathrm{J}-13$ is a reference water for the unsaturated zone near the proposed emplacement area. Well UE-25p \#1 taps the carbonate aquifer that underlies the emplacement horizon. This water has an ionic strength and total carbonate content higher by approximately an order of magnitude than Well J-13 water. UE-25p \#1 water represents natural water with the highest concentrations of dissolved species expected in the vicinity of Yucca Mountain. The water from both wells is oxidizing. Generally, radionuclide solubility studies under oxidizing conditions lead to higher solubilities for a number of radionuclides than would occur under mildly or strongly reducing conditions. These experiments will therefore provide conservative results. In this study we are reporting on the results in UE-25p \#1 water.

The maximum temperature of the host rock in which liquid water is present is expected to be limited by the boiling point of water at Yucca Mountain $\left(95^{\circ} \mathrm{C}\right)$. The solubility experiments that use Well $\mathrm{J}-13$ water were conducted at temperatures between $25^{\circ}$ and $90^{\circ} \mathrm{C}$. This span covers the range from preemplacement temperatures to the maximum temperature at which solubility would be important. For Well UE-25p \#1 water, solubility experiments were limited to a maximum temperature of $60^{\circ} \mathrm{C}$. Maximum temperatures in the saturated zone under the emplacement area and those along the flow paths away from the emplacement area are expected to be less than $60^{\circ} \mathrm{C} .5$

\section{CONCEPT OF SOLUBILITY STUDIES}

Solubility establishes an upper limit for the dissolved components in the source term for radionuclide migration from a repository. Studies of the solubility of radionuclides in groundwaters from a repository horizon will provide limits on their potential concentrations in those waters. Such limits are important for (1) validating an essential part of the radionuclide transport calculations and (2) providing guidance in choosing the maximum starting concentrations for radionuclide sorption experiments. Compared with multi-parameter transport models, laboratory solubility experiments are controlled by 
fewer variables. If geochemical codes such as EQ3/6 are to be included in the transport model, the model should be capable of predicting the results of solubility experiments.

Complete solubility experiments should provide detailed knowledge of (1) the nature and chemical composition of the solubility-controlling solid, (2) the concentration of the components in solution, and (3) the identity and electrical charge of the species in the solution phase.

Meaningful thermodynamically defined solubility studies must satisfy four criteria: (1) attainment of equilibrium conditions, (2) determination of accurate solution concentrations, (3) attainment and identification of a well-defined solid phase, and (4) knowledge of the speciation/oxidation state of the soluble species at equilibrium.

\subsection{Oversaturation and Undersaturation}

Ideally, solubility experiments should approach solution equilibrium from both oversaturation and undersaturation. The approach from oversaturation consists of adding an excess amount of the element in soluble form to the aqueous solution and then monitoring the precipitation of insoluble material until equilibrium is reached. The solid formed must then be isolated and characterized. The approach from undersaturation consists of dissolving the same well-defined solid in an aqueous solution until equilibrium is reached. In both cases, the solution concentration is measured as a function of time until equilibrium is reached.

Kinetic processes will control the equilibration speed in solubility experiments. Some solutions equilibrate rapidly, others more slowly. It must be demonstrated that equilibrium is reached. This can be accomplished by experimentally determining (for both oversaturation and undersaturation experiments) the solution concentration as a function of time. When the concentration stays constant for several weeks, it is assumed that equilibrium has been established. Because this assumption is based on judgment, the term "steady state" instead of "equilibrium" is more precise. The U.S. Nuclear Regulatory Commission (U.S. NRC) defines "steady state," as "the conditions where measurable changes in concentrations are not occurring over practical experimental times." 2 At steady state, thermodynamic forces may still change the solution composition: solids may become less soluble as they change from a higher to a lower free energy. The change may be controlled by kinetics and may therefore be very slow and may not show in the experiment even after several years. These infinitesimal changes may require infinite experimental times. The steady-state solids formed in the experiments may therefore not represent the thermodynamically most stable solids with the lowest possible solubilities, but metastable solids having higher solubilities than the thermodynamically defined solids. The term "steady state" implies this condition.

Despite this constraint, time-limited laboratory solubility experiments can supply valuable information. They provide good estimates on the upper limit of radionuclide concentrations in solution because the experimentally determined steady-state concentrations are higher than the equilibrium concentrations. 
A reliable method of proving that an equilibrium has been reached is to approach steady state from both oversaturation and undersaturation. When these two experimental approaches independently produce equal solution concentrations, the data are considered reliable. For unknown solubility systems, one should first perform experiments approaching steady-state concentration from oversaturation and then characterize the solids. This has the advantage of not specifying the solid that controls solubility but of allowing the system under investigation to determine the solid that will precipitate. These solids should be synthesized for use in confirmation experiments that approach steady state from undersaturation. In this study we are reporting results for the oversaturation experiments.

\subsection{Phase Separation}

The second criterion for meaningful solubility experiments is the derivation of accurate solution concentrations. This requires that phase separations must be as complete as possible. The separation of the solid from the solution often represents a significant practical problem in measuring solubility. Apparently higher or lower solubilities, compared with the steady-state values, can result from incomplete phase separation or from sorption of solute during and after the separation. Incomplete phase separations (leaving some of the solid with the solution phase) lead to higher radionuclide solubilities. Lower solubilities are measured if constituents of the steady-state solution have been sorbed on filters during a filtration and on container walls after the separation.

Experimentally, the solids and solutions are separated on the basis of differences in size (via filtration) or density (via sedimentation or centrifugation). Filtration is the more commonly applied technique because it physically partitions the solute and solids. Ultrafiltration (i.e., filtration using membranes $\leq 0.1 \mu \mathrm{m}$ ) can effectively remove solids and colloidal particles from aqueous solution. A potential problem with ultrafiltration is adsorption of soluble species on filtration membranes. Effective filters for solubility studies must pass soluble species quantitatively; that is, either the filter should have no active sorption sites at all or any such sites should be irreversibly blocked. Filters are adequate if they have a small enough pore size to retain the solids and colloids and if they also show no sorption or only minimal sorption during multiple filtrations. Because adsorption of soluble radionuclide species on filters can be dependent on the solution's $\mathrm{pH}$ and on the solution species, it is mandatory to verify that possible sorption sites are indeed blocked. Usually the sorptive sites on a filter and filter housing are blocked by preconditioning of these materials. The filter is preconditioned by filtering a volume of the respective radionuclide solution through it and then discarding the filtrate. The volume required for preconditioning is determined experimentally. Details for this procedure are given in Section " 4.5 Phase Separation." 


\subsection{Solid Phase}

Solubility depends strongly on the state of the solid phase. Thermodynamically meaningful results require the existence of a well-defined solid phase, which ideally consists of crystalline material. The solids formed from the oversaturation in solubility tests must be clearly identified by physical or chemical characterization methods. Only when identified unambiguously can the solid be synthesized for use in undersaturation solubility tests. Radionuclide solids formed in laboratory experiments and in nature are often thermodynamically ill-defined amorphous precipitates. Most amorphous solids, however, will become more crystalline with time. Freshly precipitated microcrystalline solids can also convert in time to a macrocrystalline material. Improved bonding at the lattice surface results in decreasing surface area. Thus the crystalline solid of higher free energy changes to one of lower free energy (Ostwald ripening, Ostwald step rule) and becomes less soluble. ${ }^{6,7,8,9}$

\subsection{Determination of Oxidation States and Speciation}

Information on oxidation states and speciation of the radionuclides in steady-state solubility solution is important for transport models simulating migration and sorption along the flow path to the accessible environment. The charge and speciation of radionuclides will control their sorption and transportation in the geologic host. Speciation measurements identify complexes that may form between radionuclides and complexing ions present in the groundwater near the repository. Radionuclides, like all nuclides, can have a single or several different oxidation states in solution. They can be present as simple ions or as complexes. When the ions react with one or several other solution components, they can form soluble complexes.

Oxidation states and speciation in solution are commonly determined by (1) absorption spectrophotometry, (2) ion exchange chromatography, (3) solvent extraction, (4) coprecipitation, (5) potentiometry, and (6) electrochemistry. Of these methods, only absorption spectrophotometry can provide information on speciation, while the others identify only the oxidation state in solution.

Absorption spectrophotometry in UE-25p \#1 water has a detection limit of about $10^{-5} \mathrm{M}$. This relatively high concentration limits the application of spectrophotometry for speciation determination in solutions from radionuclide solubility studies because the solubilities can be several orders of magnitude below $10^{-6} \mathrm{M}$. Laser-Induced Photoacoustic Spectroscopy (LIPAS) provides much greater sensitivity, approaching $10^{-8}$ to $10^{-9} \mathrm{M} \cdot 10,11,12,13,14$

The methods listed above as 2 through 6 determine only the oxidation state in solution because they cannot determine species. They detect the oxidation state of ions indirectly. This process is different from absorption spectrophotometry, which detects oxidation states and sometimes the solution species directly. The indirect methods, however, detect very small concentrations ( $10^{-10} \mathrm{M}$ and below), which is useful for radionuclide solubility studies. Solvent extraction and coprecipitation are often used successfully to determine the oxidation states of ions in very dilute solutions. ${ }^{13}$ Ion exchange chroma- 
tography is less reliable for this purpose because the exchange resin often reduces the solution ions, which gives incorrect results for the oxidation state distribution. Electrochemical detection reduces or oxidizes the solution ions and measures the potentials of the reduction and oxidation reactions, respectively. The potential then identifies the individual ion. Electrochemistry needs fast kinetics and reversible thermodynamics for the reduction or oxidation step. These experiments greatly limit the method because many radionuclide ion redox reactions are irreversible and slow (e.g., the reactions of $\left.\mathrm{NpO}_{2}{ }^{+} / \mathrm{Np}^{4+}, \mathrm{PuO}_{2}{ }^{+} / \mathrm{Pu}^{4+}\right)$.

The neptunium solution species were determined by spectrophotometry because the solution concentration was greater than $10^{-5} \mathrm{M}$. The oxidation state of plutonium and americium species in solution were determined by a solvent extraction technique, which is described in principle by Nitsche et al. ${ }^{15}$ and in detail in Section 5.2.2.

The sensitivity of the available analytical methods for plutonium limits this part of our study. LIPAS was needed to determine directly the species in the supernatant solutions of the solubility experiments at submicromolar concentrations. An activity related to the far-field studies has developed this capability for the YMP in Los Alamos, but it is not feasible to transport the equilibrated solutions over the long distance from the Lawrence Berkeley Laboratory to the Los Alamos National Laboratory because it can be expected that the attained solution equilibrium will be disturbed. This certainly applies for the $60^{\circ} \mathrm{C}$ samples and probably for the $25^{\circ} \mathrm{C}$ samples as well. 


\section{EXPERIMENTAL DETAILS}

We studied the solubilities of neptunium, plutonium, and americium at $25^{\circ}$ and $60^{\circ} \mathrm{C}$ and respective $\mathrm{pH}$ values of 6.0,7.0, and 8.5. Measurements were made in an inert-atmosphere box to avoid contamination of solutions by atmospheric $\mathrm{CO}_{2}$. The solubilities were studied from oversaturation by injecting a small amount of actinide stock solution into $80 \mathrm{~mL}$ of groundwater obtained from Well UE$25 p \# 1$. The analysis of the water composition is listed in Table IV. ${ }^{4}$

Table IV. UE-25p \#1 Water Composition ${ }^{4}$

\begin{tabular}{|c|c|}
\hline Species & Concentration, $\mathrm{mM}$ \\
\hline $\mathrm{Na}^{+}$ & 7.43 \\
\hline $\mathrm{K}^{+}$ & 0.34 \\
\hline $\mathrm{Ca}^{2+}$ & 2.19 \\
\hline $\mathrm{Mg}^{2+}$ & 1.31 \\
\hline $\mathrm{SiO}_{2}$ & 0.62 \\
\hline $\mathrm{Cl}^{-}$ & 1.04 \\
\hline $\mathrm{SO}_{2}^{2-}$ & 1.34 \\
\hline $\mathrm{F}^{-}$ & 0.18 \\
\hline Total Alkalinity & 11.44 mequiv./L \\
\hline Total Carbonate & 15.31 \\
\hline $\mathrm{pH}$ & 6.7 \\
\hline Eh $(\mathrm{mV})$ & 360 \\
\hline Ionic Strength (mM) & -20 \\
\hline
\end{tabular}


The UE-25p \#1 groundwater was sampled at the site by Los Alamos personnel. It was filtered at Los Alamos before it was shipped to LBL. The water's natural carbon dioxide partial pressure $\left(\mathrm{pCO}_{2}\right)$ could not be preserved during filtration and shipping. For the experiments, however, the natural state was induced by re-equilibrating the water with $\mathrm{CO}_{2}$ gas. Details of this procedure are described in paragraphs "4.3. Pressure Control System," and "4.4. Solutions." Details of the filtration are described in paragraph "4.4. Solutions." The polyethylene shipping bottle was leached with acid and distilled water prior to its use for the groundwater. The leaching removes possible trace-level contaminants that may alter the composition of the UE-25p \#1 water.

\subsection{Controlled-Atmosphere Glove Box}

Due to the radiation hazard of the actinide elements under investigation, all experimental work was performed in glove boxes. External $\mathrm{CO}_{2}$ control of the experimental solutions requires the exclusion of atmospheric $\mathrm{CO}_{2}$. To satisfy both conditions, we used a controlled-atmosphere glove box.

\subsection{Control System for $\mathrm{pH}$ and Temperature}

Because the solubilities are highly sensitive to $\mathrm{pH}$ and temperature changes, close control of these parameters is necessary. We designed a computer-operated control system ( $\mathrm{pH}$-stat) to maintain the aqueous actinide solutions at constant temperatures and $\mathrm{pH}$ values for the solubility experiments. ${ }^{16}$ The $\mathrm{pH}$-stat records and adjusts the $\mathrm{pH}$ values of the experimental solutions (UE-25p \#1 water) at the target values with standard deviations not exceeding $0.1 \mathrm{pH}$ unit. It uses small amounts (usually between 5 to 50 microliters) of dilute (0.05-0.1 M) $\mathrm{HClO}_{4}$ or $\mathrm{NaOH}$ solution for the pH adjustments.

In the UE-25p \#1 water experiments at $25^{\circ} \mathrm{C}$, the $\mathrm{pH}$-stat was used to monitor and adjust the $\mathrm{pH}$. At $60^{\circ} \mathrm{C}$, deviations from the target $\mathrm{pH}$ occurred quite frequently, so computer controlled $\mathrm{pH}$ adjustment was stopped ( $\mathrm{pH}$ monitoring and data acquisition, however, were not) and daily $\mathrm{pH}$ adjustment was performed manually. Temperatures at $25^{\circ}$ and $60^{\circ} \mathrm{C}$ were controlled within less than $1^{\circ} \mathrm{C}$.

\subsection{Pressure Control System}

We designed and manufactured a pressure regulation system to maintain the well waters used in experiments at their nominal carbonate concentrations when their temperatures and $\mathrm{pH}$ values are adjusted to conditions differing from their natural state. The system also ensured that no significant evaporative loss of the solutions occurred at elevated temperatures. 


\subsection{Solutions}

The actinide stock solutions were prepared by using established methods. ${ }^{17}{ }^{237} \mathrm{~Np}(\mathrm{~V})$ stock solutions were prepared by dissolving its oxide in $\mathrm{HCl}$. ${ }^{239} \mathrm{Pu}(\mathrm{IV})$ stock was prepared from plutonium metal. Stable neodymium(III) was used as an analogue for americium(III). ${ }^{1}$ It was prepared by dissolving $\mathrm{Nd}_{2} \mathrm{O}_{3}$ in $\mathrm{HClO}_{4}$. The solution was then spiked with purified ${ }^{241} \mathrm{Am}$ (III) tracer to enable the use of nuclear counting for the determination of the neodymium solution concentrations. Further details for these ${ }^{241} \mathrm{Am} / \mathrm{Nd}$ mixtures are given in section 5.3. The actinide solutions were purified from possible metal contaminants by ion exchange chromatography. For neptunium and plutonium, anion exchange was used, while cation exchange was employed for americium. The solutions were converted to a noncomplexing perchlorate system. The neptunium and plutonium stock solutions were in the +6 oxidation state after their conversion to perchloric acid $\left(2\right.$ to $3 \mathrm{M}$ ) and were reduced electrolytically to $\mathrm{NpO}_{2}{ }^{+}$and $\mathrm{Pu}^{3+}$, respectively. $\mathrm{Pu}^{4+}$ was prepared by electrolytic oxidation of pure $\mathrm{Pu}^{3+}$ immediately before the start of the plutonium solubility experiments in order to minimize the disproportionation of $\mathrm{Pu}^{4+} .18,19,20$ Valence purity of the stock solutions was established hy absorption spectrophotometry. ${ }^{21,22}$ Oxidation states other than Pu(IV) were not detected. With our absorption spectrophotometer (Guided Wave Model 260, El Dorado Hills, CA), the limits of detection for $\mathrm{Pu}(\mathrm{III}), \mathrm{Pu}(\mathrm{V})$, and $\mathrm{Pu}(\mathrm{VI})$ are approximately $10^{-4}, 3 \times 10^{-4}$, and $10^{-5} \mathrm{M}$, respectively.

The groundwater was filtered through $0.05 \mu \mathrm{m}$ polycarbonate membrane filters (Nuclepore Corp., Pleasanton, CA). This filtration was carried out by Los Alamos personnel prior to shipping the UE-25p \# 1 water sample to LBL. The actinide stock solutions, and all other solutions utilized in this experiment were filtered through $0.22 \mu \mathrm{m}$ polyvinylidene difluoride syringe filter units (Millipore Corp., Bedford, MA). Filtration was used to remove suspended particulate material, e.g., dust or silica, that could absorb the actinide ions to form pseudocolloids. Before adding between 1 and $4 \mathrm{~mL}$ of the actinide stock solutions to approximately $80 \mathrm{~mL}$ of UE-25p \#1 water, a small amount of $\mathrm{CO}_{2}$-free sodium hydroxide solution was added in order to keep the $\mathrm{pH}$ values at or above the desired solution $\mathrm{pH}$. Letting the $\mathrm{pH}$ drop below the target value would necessitate addition of concentrated base to the system while the actinide ion is already present in the solution. Addition of strong base can result in unpredictable microprecipitation and formation of microcolloids.

When we started the neptunium experiments at $25^{\circ} \mathrm{C}$, we added small volumes of $5 \mathrm{M}$ sodium hydroxide to the UE-25p\#1 groundwater to neutralize the perchloric acid that would be introduced with the stock solution. We added the acidic stock followed by $1 \mathrm{M}$ perchloric acid, $1 \mathrm{M}$ sodium hydroxide, or both if necessary, to attain the desired $\mathrm{pH}$ for the experiment. For the experiment at $\mathrm{pH} 6$, the total amount of sodium hydroxide and perchloric acid added to the solution led to additional concentrations of 91 and $130 \mathrm{mM}$ for $\mathrm{Na}^{+}$and $\mathrm{ClO}_{4}{ }^{-}$, respectively. These additions increased the total concentration of $\mathrm{Na}^{+}$and the ionic strength by factors of about 12 and 6.5 , respectively. For the experiment at $\mathrm{pH} 7$, the total amount of sodium hydroxide and perchloric acid added to the solution led to additional concentrations of 42 and $46 \mathrm{mM}$ for $\mathrm{Na}^{+}$and $\mathrm{ClO}_{4}{ }^{-}$, respectively. This increased the total concentration 
of $\mathrm{Na}^{+}$by a factor of about 5.6 and the ionic strength by a factor of about 3.2 . For the experiment at $\mathrm{pH}$ 8.5 , we increased the concentrations of $\mathrm{Na}^{+}$and $\mathrm{ClO}_{4}{ }^{-}$by 96 and $84 \mathrm{mM}$, respectively. This increased the total concentration of $\mathrm{Na}^{+}$and the ionic strength by factors of about 13 and 5.5, respectively.

For the $60^{\circ} \mathrm{C}$ experiments, the additions were slightly smaller. At $\mathrm{pH} 6$, the added acid and base led to additional concentrations of $\mathrm{Na}^{+}$and $\mathrm{ClO}_{4}{ }^{-}$of 53 and $8.9 \mathrm{mM}$, respectively, resulting in a higher initial concentration of $\mathrm{Na}^{+}$by a factor of about 8.2 and an initial ionic strength about 4.9 times higher than that of UE-25p \#1 water. At $\mathrm{pH} \mathrm{7}$, addition of only sodium hydroxide increased the $\mathrm{Na}^{+}$ concentration by $9.6 \mathrm{mM}$. This increased the ionic strength by only 25 percent. At $\mathrm{pH} 8.5$, additions of $\mathrm{NaOH}$ and $\mathrm{HClO}_{4}$ increased the respective $\mathrm{Na}^{+}$and $\mathrm{ClO}_{4}^{-}$concentrations by 23 and $7.5 \mathrm{mM}$. This increased the $\mathrm{Na}^{+}$content and the ionic strength by factors of about 4.1 and 1.8, respectively.

For the plutonium experiments, we also added $5 \mathrm{M} \mathrm{NaOH}$ to the UE-25p \#1 water before we introduced the acidic plutonium stock solution. For the $25^{\circ} \mathrm{C}$ experiments, the plutonium stock solution was $5.6 \times 10^{-3} \mathrm{M}$ in total plutonium and $3.6 \mathrm{M}^{\text {in }} \mathrm{HClO}_{4}$. For the experiments at $\mathrm{pH} 6$ and 8.5 , the total amount of sodium hydroxide and perchloric acid added to each of the solutions led to additional concentrations of 220 and $210 \mathrm{mM}$ for $\mathrm{Na}^{+}$and $\mathrm{ClO}_{4}{ }^{-}$, respectively. For the experiment at $\mathrm{pH} 7$, the total amount of sodium hydroxide and perchloric acid added to the solution led to additional concentrations for $\mathrm{Na}^{+}$and $\mathrm{ClO}_{4}^{-}$of $210 \mathrm{mM}$ each. In each of the three experiments, the addition of acid and base increased the total concentration of $\mathrm{Na}^{+}$by a factor of about 30 and the ionic strength by a factor of about 12.

At $60^{\circ} \mathrm{C}$, the additions of acid and base were smaller, and the resulting changes in the water composition were not so large. The plutonium stock solution was $7.9 \times 10^{-3} \mathrm{M}$ in total plutonium and 3.0 $\mathrm{M}$ in $\mathrm{HClO}_{4}$. We used less plutonium to start the experiments, so we needed smaller amounts of acid and base to adjust the starting $\mathrm{pH}$. At $\mathrm{pH} 6$ and 7, adjustments led to additional concentrations of $\mathrm{Na}^{+}$ and $\mathrm{ClO}_{4}{ }^{-}$of 21 and $80 \mathrm{mM}$, respectively. These additions increased the sodium content and the ionic strength in both experiments by factors of about 3.8 and 3.6, respectively. For the pH 8.5 experiment, acid and base adjustments led to additional concentrations of $\mathrm{Na}^{+}$and $\mathrm{ClO}_{4}^{-}$of 22 and $95 \mathrm{mM}$, respectively. This increased the $\mathrm{Na}^{+}$content and the ionic strength by factors of about 4.0 and 3.9 , respectively.

For the neodymium/americium experiments, we used even smaller amounts of $5 \mathrm{M} \mathrm{NaOH}$ because the $\mathrm{Nd} / \mathrm{Am}$ stock solution was $1 \mathrm{M}$ in $\mathrm{HClO}_{4}$. At $\mathrm{pH} 6$ and $25^{\circ} \mathrm{C}$, we only increased the sodium content by $15 \mathrm{mM}$ and the perchlorate content to $14 \mathrm{mM}$, which increased the sodium content and the ionic strength by factors of about 3.0 and 1.8, respectively. At pH 7, additions increased the $\mathrm{Na}^{+}$and $\mathrm{ClO}_{4}^{-}$concentrations by $14 \mathrm{mM}$ each. This increased the initial amount of sodium and the ionic strength by factors of about 2.9 and 1.7 , respectively. At pH 8.5 , additions increased the $\mathrm{Na}^{+}$and $\mathrm{ClO}_{4}{ }^{-}$ concentrations by 25 and $14 \mathrm{mM}$, respectively. This increased the initial amount of sodium and the ionic strength by factors of about 4.4 and 2.0 , respectively.

For the $\mathrm{pH} 6$ experiment at $60^{\circ} \mathrm{C}$, addition of acid and base, including the stock solution that was again $1 \mathrm{M}$ in $\mathrm{HClO}_{4}$, increased the $\mathrm{Na}^{+}$and $\mathrm{ClO}_{4}{ }^{-}$concentrations by 14 and $20 \mathrm{mM}$, respectively. This 
increased the initial amount of sodium and the ionic strength by factors of about 2.9 and 1.9, respectively. At $\mathrm{pH} 7$, additions increased the $\mathrm{Na}^{+}$and $\mathrm{ClO}_{4}$ " concentrations by 15 and $17 \mathrm{mM}$, respectively, increasing the sodium content and the ionic strength by factors of about 3.0 and 1.8 , respectively. At pH 8.5, additions increased the $\mathrm{Na}^{+}$and $\mathrm{ClO}_{4}{ }^{-}$concentrations by 19 and $17 \mathrm{mM}$, respectively. This increased the initial amount of sodium and the ionic strength by factors of about 3.5 and 1.9 , respectively.

In summary, initial additions of sodium hydroxide and perchloric acid to the neptunium experiments increased the total $\mathrm{Na}^{+}$content by factors that ranged from 2.3 to 13 times the original amount found in UE-25p \#1 water and increased the ionic strength of the solutions by factors ranging from 1.3 to 6.5. Additions of acid and base at the start of the plutonium experiments increased the total $\mathrm{Na}^{+}$content by factors that ranged from 3.8 to 30 resulting in ionic strengths that were higher than that of UE-25p \#1 well water by factors that ranged from 3.6 to 12 . And for the neodymium/americium experiments, additions of acid and base at the start of the experiments increased the initial sodium content by factors that ranged from 2.9 to 4.4 resulting in initial ionic strengths higher by factors that ranged from 1.7 to 2.0 .

The well water's total dissolved carbonate $\left(1.531 \times 10^{-2} \mathrm{M}\right)$ was preserved at each individual $\mathrm{pH}$ and temperature by equilibrating the solution with mixtures of $\mathrm{CO}_{2}$ in argon. ${ }^{4}$ The amount of $\mathrm{CO}_{2}$ at a given $\mathrm{pH}$ and temperature was calculated from Henry's constant and the dissociation constants of carbonic acid from literature data. ${ }^{23}$ If the value at the given temperature was not available, the number was derived by interpolation of adjacent values. Activity coefficients were adjusted for ionic strength using the Davies equation. The concentrations of the equilibration gas mixtures are given in Table $\mathrm{V}$ together with the dissociation constants used to determine them.

The test solutions were kept in $90 \mathrm{~mL}$ cells that were made of either Teflon Perfluoralkoxy (TPFA) or Polyether etherketone (PEEK). ${ }^{24}$ All cells had sealed ports at the top that accommodate the permanent emplacement of a pH electrode, an opening to draw samples, and three 1/16" diameter Teflon lines for addition of acid, base, and the $\mathrm{CO}_{2}$-argon mixture. The temperature was controlled by placing the test cells in a heated aluminum block of LBL design. The electric heater was mounted on an orbital shaker (Lab-Line Inc., Melrose Park, IL), and all solutions were shaken continuously at approximately 100 rpm. The solutions' $\mathrm{pH}$ values were controlled by a computer-operated $\mathrm{pH}$ control system (pH-stat, see section 4.2). Combination pH electrodes from Beckman Instr. Inc., Model 39522 were used to monitor the solutions $\mathrm{pH}$ values at $25^{\circ} \mathrm{C}$, and electrodes from Broadley-James Corp., Model E$1393 \mathrm{EC} 1-\mathrm{A03BC}$ were used at $60^{\circ} \mathrm{C}$. 
Table V. Concentrations (in percent) of carbon dioxide gas in argon to maintain a total dissolved carbonate concentration of $1.531 \times 10^{-2} \mathrm{M}$ in UE-25p \#1 water at different $\mathrm{pH}$ and temperatures together with the values for Henry's constant and the dissociation constants for carbonic acid used to determine the $\mathrm{pCO}_{2}$ values.

\begin{tabular}{|l|c|c|}
\cline { 2 - 3 } \multicolumn{1}{c|}{} & $25^{\circ} \mathrm{C}$ & $60^{\circ} \mathrm{C}$ \\
\hline $\mathrm{pH} 6$ & 28.44 & 52.03 \\
\hline $\mathrm{pH} 7$ & 6.555 & 11.22 \\
\hline $\mathrm{pH} 8.5$ & 0.2353 & 0.3909 \\
\hline
\end{tabular}

\begin{tabular}{|c|c|c|}
\cline { 2 - 3 } \multicolumn{1}{c|}{} & $25^{\circ} \mathrm{C}$ & $60^{\circ} \mathrm{C}$ \\
\hline $\mathrm{pK}_{\mathrm{H}}$ & 1.47 & 1.77 \\
\hline $\mathrm{pK}_{1}$ & 6.23 & 6.17 \\
\hline $\mathrm{pK}_{2}$ & 10.09 & 9.91 \\
\hline
\end{tabular}

The combination $\mathrm{pH}$ electrodes from Broadley-James Corp. were used in the $60^{\circ} \mathrm{C}$ experiments because of their expectedly hetter long-term pH stability at $60^{\circ} \mathrm{C}$ than the Beckman electrodes. These electrodes, however, went out of calibration much sooner at $60^{\circ}$ than at $25^{\circ} \mathrm{C}$. Often, the computer controlled monitoring of the $\mathrm{pH}$ showed deviations of up to 0.2 units. These deviations were the result of the electrode's going out of calibration, and not a result of the instability of the experimental equilibria. Therefore, we did not use the $\mathrm{pH}$-stat for $\mathrm{pH}$ adjustment in the $60^{\circ} \mathrm{C}$ experiments. To avoid unnecessary $\mathrm{pH}$ adjustment in the $60^{\circ} \mathrm{C}$ experiments, we calibrated the electrodes more often than in the $25^{\circ} \mathrm{C}$ experiments and only adjusted the solution's $\mathrm{pH}$ by hand after the calibration. The deterioration of the electrode is mainly due to the dissolution of the $\mathrm{Ag} / \mathrm{AgCl}$ layer of the reference electrode wire and also of the wire used in the $\mathrm{pH}$ sensing compartment itself; the solubility of $\mathrm{AgCl}$ increases approximately 240 times when the temperature changes from $10^{\circ}$ to $100^{\circ} \mathrm{C}$. Although the manufacturer claims the working range of these electrodes is up to $100^{\circ} \mathrm{C}$, we were unable to use the electrodes continuously with $\mathrm{pH}$-stat computer controlled $\mathrm{pH}$ adjustment. Therefore, we allowed $\mathrm{pH}$-stat to continuously monitor the $\mathrm{pH}$, but we performed the $\mathrm{pH}$ adjustment by hand.

The effect on the composition of the UE-25p \#1 groundwater due to the addition of acid and/or base during the experiment is a rather complicated one. At the start of the experiments, the ionic strengths of the solutions were increased by factors that ranged from 1.3 to 12 simply with the introduction of the actinide stock solutions and the sodium hydroxide needed to neutralize the perchloric acid in the stock solutions. Therefore, the initial ionic strengths ranged from $\sim 0.03$ to $0.2 \mathrm{M}$. During the course of the solubility experiments, $0.1 \mathrm{M}$ perchloric acid and sodium hydroxide were used to maintain the desired $\mathrm{pH}$ of the solubility experiments. Also during that time, we assayed the solutions for concentration and speciation determinations. The volumes of acid and base added to the experiments ranged from 2 to over $20 \mathrm{~mL}$; whereas, to perform all of the concentration and speciation determinations throughout the experiment, we removed 30 to $50 \mathrm{~mL}$ of solution. The net effect on $70 \mathrm{~mL}$ of an initially $0.04 \mathrm{M}$ solution in removing $50 \mathrm{~mL}$ for assays and then adding $20 \mathrm{~mL}$ of $0.1 \mathrm{M}$ acid and/or base solutions to adjust the $\mathrm{pH}$ would result in increasing the ionic strength to approximately $0.07 \mathrm{M}$. For solutions that were initially 
$0.1 \mathrm{M}$, they would remain at roughly the same ionic strength. For solutions that were initially $0.2 \mathrm{M}$, they would be diluted to $\sim 0.15 \mathrm{M}$. Therefore, in these cases we would have final ionic strengths that range from $\sim 0.07$ to $0.15 \mathrm{M}$. In all cases, however, the constituents in UE-25p \#1 groundwater other than sodium (and perchlorate) would be diluted by roughly a factor of 7 . Of course the solutions to which we added very little acid and/or base, the final ionic strengths will be closer to their initial ionic strengths. The addition of acid and/base, however, ran concurrently with the removal of solution volumes for assays, so it is rather difficult to establish exactly the true ionic strength of these solutions at the conclusion of the experiments.

The addition of acid and base to the solutions during the course of the experiments appears to have had an averaging effect on the ionic strength of the solutions when compared with the effect of introducing the actinide stock solutions. Upon starting the experiments, the ionic strengths ranged from $\sim 0.03$ to $0.2 \mathrm{M}$, but by adding $0.1 \mathrm{M}$ solutions of acid and base during the course of the experiments, we narrowed that range. With an approximate analysis based on final volumes, we can only say that the final ionic strengths in all of the solubility experiments were probably closer to $0.1 \mathrm{M}, \pm 50 \%$, and that the primary constituents are sodium and perchlorate. This five fold increase in the ionic strength of UE-25p \#1 groundwater definitely shows the difficulties in trying to maintain constant solution conditions in long term solubility experiments such as these.

\subsection{Phase Separation}

Achievement of steady-state conditions for the solubility measurements was monitored by sampling aliquots of the solution phases and analyzing for the respective radioisotope as a function of time. We used Centricon-30 centrifugal filters (Amicon Corp., Danvers, MA) for separating the phases of the neptunium, plutonium, and americium solutions. For the separations, the centrifuge (High-speed centrifuge, Model HSC-1000, Savant Instruments Inc.) was heated with a circulating water bath to the appropriate temperature. The filters contain a YM-type membrane with a calculated pore size of $4.1 \mathrm{~nm}$. To ascertain that we achieved complete phase separation and minimal adsorption on the filters during the preparation of the solution assays, we conducted a series of filtration tests.

For each solution, these tests were done at different times during the equilibration period. We used one filter per solution and filtered consecutive $500 \mu \mathrm{L}$ portions of solution through it. Each filtrate was acidified to minimize sorption in the filtrate-collection container and an assay was taken. The concentration was plotted as a function of total volume passed through the filter. This was repeated until the assays showed a constant concentration. The volume necessary to saturate the filter was the cumulative amount of volumes used until the assay concentration remained constant. The presaturation volume was radionuclide-dependent.

We determined and used the following preconditioning volumes: $500 \mu \mathrm{L}, 500 \mu \mathrm{L}$, and 1500 to $2500 \mu \mathrm{L}$ for the neptunium, plutonium, and neodymium/americium solutions, respectively. 


\subsection{Analysis}

After separation of the solution and the solid phases, the two components were analyzed separately. Concentration measurements of the supernatants were made by counting liquid aliquots with a germanium low-energy counting system (LBL design). For ${ }^{237} \mathrm{~Np}$ and ${ }^{241} \mathrm{Am}$, the $29.38 \mathrm{keV}$ and 59.54 $\mathrm{keV}$ - $\gamma$-ray lines were used, respectively. ${ }^{239} \mathrm{Pu}$ was analyzed by utilizing the $U L \mathrm{X}$-rays coming from the $\alpha$-decay of the plutonium. Possible contributions to the $L x$-rays from the decays of other radionuclides, also present in small amounts, were corrected by subtraction. ${ }^{25}$ In selected cases, liquid scintillation counting was also used for plutonium concentration determinations (LKB Instruments, Inc., Wallac Oy, Model 1219 RackBeta). We used the "Pulse Shape Analysis" feature of the 1219 RackBeta to discriminate all $\beta$-emitting solution contaminants from the plutonium $\alpha$-radiation. Repeated sample counting and the observation of a constant count rate in the $\alpha$-window ensured no $\beta$-contribution to the $\alpha$-count.

\subsection{Criteria for Steady-State Concentrations}

Constant concentrations over time with minimal deviation during that time span are the criteria for determining the average steady-state concentration from the individual concentration measurements. For experiments in which the aqueous concentration continually increases (or decreases), the final steady-state concentration will be equal to the final concentration measurement taken from the experiment. This concentration may not be the actual steady-state concentration, and all that can be stated is that the steady-state concentration is probably greater than (or less than) or equal to the value reported.

These limits depend on the solubility of the nuclide involved and the temperature of the experiment. High solubilities yield precise concentrations within short counting times; whereas, low solubilities yield concentrations with large errors, even after very long counting times. Experiments at ambient temperatures lead to very consistent concentrations. Elevated temperatures, however, lead to greater deviations in concentration because of the difficulties involved in maintaining elevated temperature during phase separation and sample preparation.

\subsection{Eh Measurements}

We are aware of the problems associated with Eh measurements in groundwater systems. Lindberg and Runnells ${ }^{26}$ point out that in the apparent absence of an internal redox equilibrium, as it is the case for many groundwater systems, Eh measurements may not accurately predict the equilibrium chemistry of the system. Because our experimental systems contained a very limited number of components and may be well poised, we measured the Eh at the end of each solubility experiment. In several cases, we obtained stable readings only after measuring as long as 24 hours. This drifting does 
not lend much confidence in the obtained Eh value. Despite these limitations, we conducted these measurements in order to supply future chemical modeling efforts (neptunium, plutonium, and americium solubilities in UE-25p \# 1 water solutions) with an approximate value indicating the general oxic nature of the system. Without modeling, however, the Eh measurements are only of limited value, because they may represent a combination of many different redox reactions for each individual solubility solution despite the limited number of components.

We measured the Eh with a platinum electrode versus a $\mathrm{Ag} / \mathrm{AgCl} /$ sat. $\mathrm{NaCl}$ reference. We cleaned the platinum electrode with $6 \mathrm{M} \mathrm{HNO}_{3}$ before and after each measurement. The electrode setup was checked with "Zobell Solution" before and after each measurement. 27,28

\subsection{Identification of Solids}

The solid compounds were analyzed by $x$-ray powder diffraction measurements. A few micrograms of each actinide precipitate were placed in a $0.33 \mathrm{~mm}$ diameter quartz capillary tube, and the tube was sealed with an oxy-butane microtorch. The tube was mounted in an $11.46 \mathrm{~cm}$ diameter Debye-Scherrer camera and then irradiated with $\mathrm{x}$-rays from a Norelco III $\mathrm{x}$-ray generator (Phillips Electronics, Inc.). Copper $\mathrm{K}_{\alpha}$ radiation filtered through nickel was used. 


\section{RESULTS AND DISCUSSION}

\subsection{Neptunium}

\subsubsection{Solubility}

Results of the neptunium solubility studies are shown in Figure 1. The neptunium was initially introduced as $\mathrm{NpO}_{2}{ }^{+}$into the UE-25p \#1 groundwater. The steady-state concentrations and the solutions' Eh values are given in Table VI. Concentration profiles as a function of equilibration time and $\mathrm{pH}$ for $25^{\circ}$ and $60^{\circ} \mathrm{C}$ are shown in Figures 2 and 3, respectively. The individual measurements are listed in Appendix A. Representative results from neptunium filtration experiments at $25^{\circ}$ and $60^{\circ} \mathrm{C}$ are shown in Figures in 4 and 5, respectively. The filtration experiments are described in section 4.5. We could not find any volume effect for the neptunium, so we used $500 \mu \mathrm{L}$ of solution as presaturation volume for routine separations.

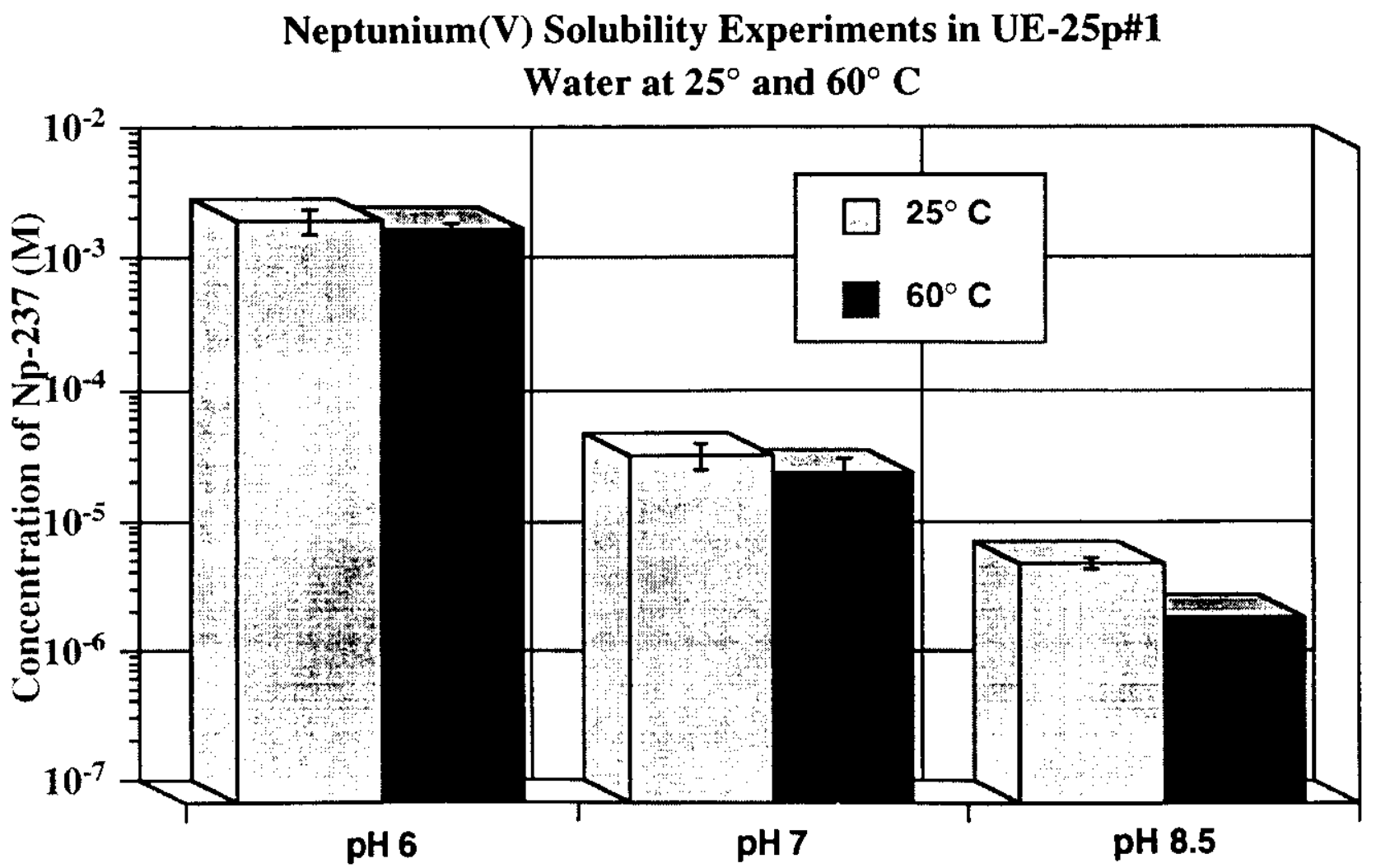

Figure 1. Results of the neptunium solubility experiments in UE-25p \#1 groundwater as a function of $\mathrm{pH}$ and temperature. 
Table VI. Comparison of steady-state solution concentrations and Eh for neptunium in UE-25p \#1 water at $25^{\circ}$ and $60^{\circ} \mathrm{C}$.

\begin{tabular}{|c|c|c|c|c|}
\hline \multirow{2}{*}{$\mathrm{p}$} & \multicolumn{4}{|c|}{ Neptunium(V) } \\
\cline { 2 - 5 } & \multicolumn{3}{|c|}{ Concentration (M) } & \multicolumn{2}{c|}{ Eh (mV vs. NHE) } \\
\cline { 2 - 5 } & $25^{\circ} \mathrm{C}$ & $60^{\circ} \mathrm{C}$ & $25^{\circ} \mathrm{C}$ & $60^{\circ} \mathrm{C}$ \\
\hline 6 & $(2.9 \pm 0.6) \times 10^{-3}$ & $(2.5 \pm 0.2) \times 10^{-3}$ & $(877 \pm 15)$ & $(414 \pm 15)$ \\
\hline 7 & $(4.7 \pm 1.1) \times 10^{-5}$ & $(3.4 \pm 1.0) \times 10^{-5}$ & $(438 \pm 15)$ & $(367 \pm 15)$ \\
\hline 8.5 & $(7.0 \pm 0.6) \times 10^{-6}$ & $(2.7 \pm 0.1) \times 10^{-5}$ & $(259 \pm 15)$ & $(212 \pm 15)$ \\
\hline
\end{tabular}

Approach to Equilibrium of UE-25p\#1 Water Solutions of Neptunium(V) at $25^{\circ} \mathrm{C}$

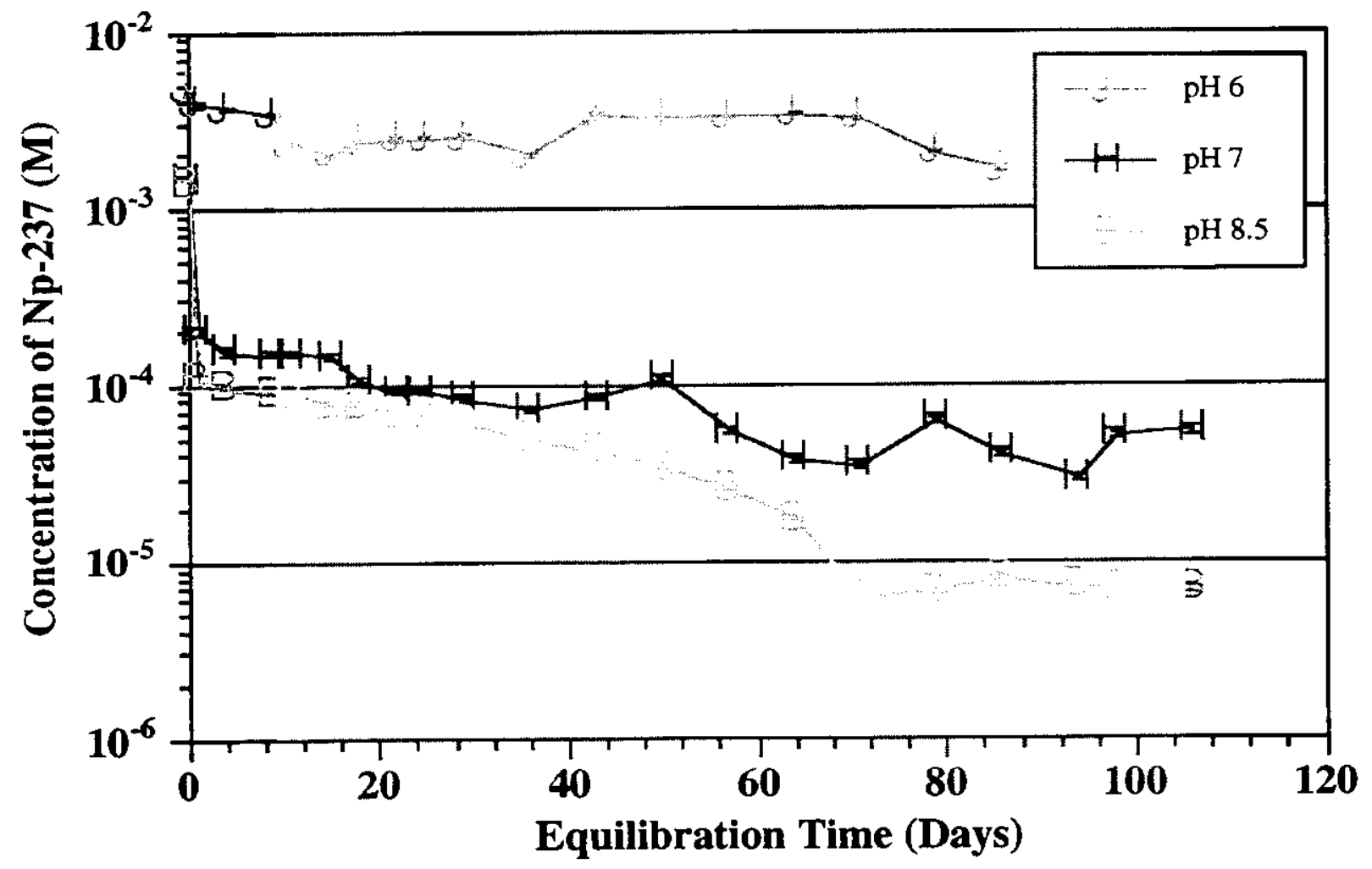

Figure 2. Solution concentrations of ${ }^{237} \mathrm{~Np}$ in contact with precipitate obtained from supersaturation of UE-25p \#1 groundwater at $25^{\circ} \mathrm{C}$ as a function of time. pH $6.0 \pm 0.1$ (closed circles), $\mathrm{pH} 7.0 \pm 0.1$ (closed triangles), and $\mathrm{pH} 8.5 \pm 0.1$ (closed squares). The neptunium was added initially (day 0 ) as $\mathrm{NpO}_{2}+$; initial concentrations were $4.8 \times 10^{-3} \mathrm{M}(\mathrm{pH} 6), 1.5$ $\times 10^{-3} \mathrm{M}(\mathrm{pH} 7)$, and $1.4 \times 10^{-3} \mathrm{M}(\mathrm{pH} 8.5)$. 


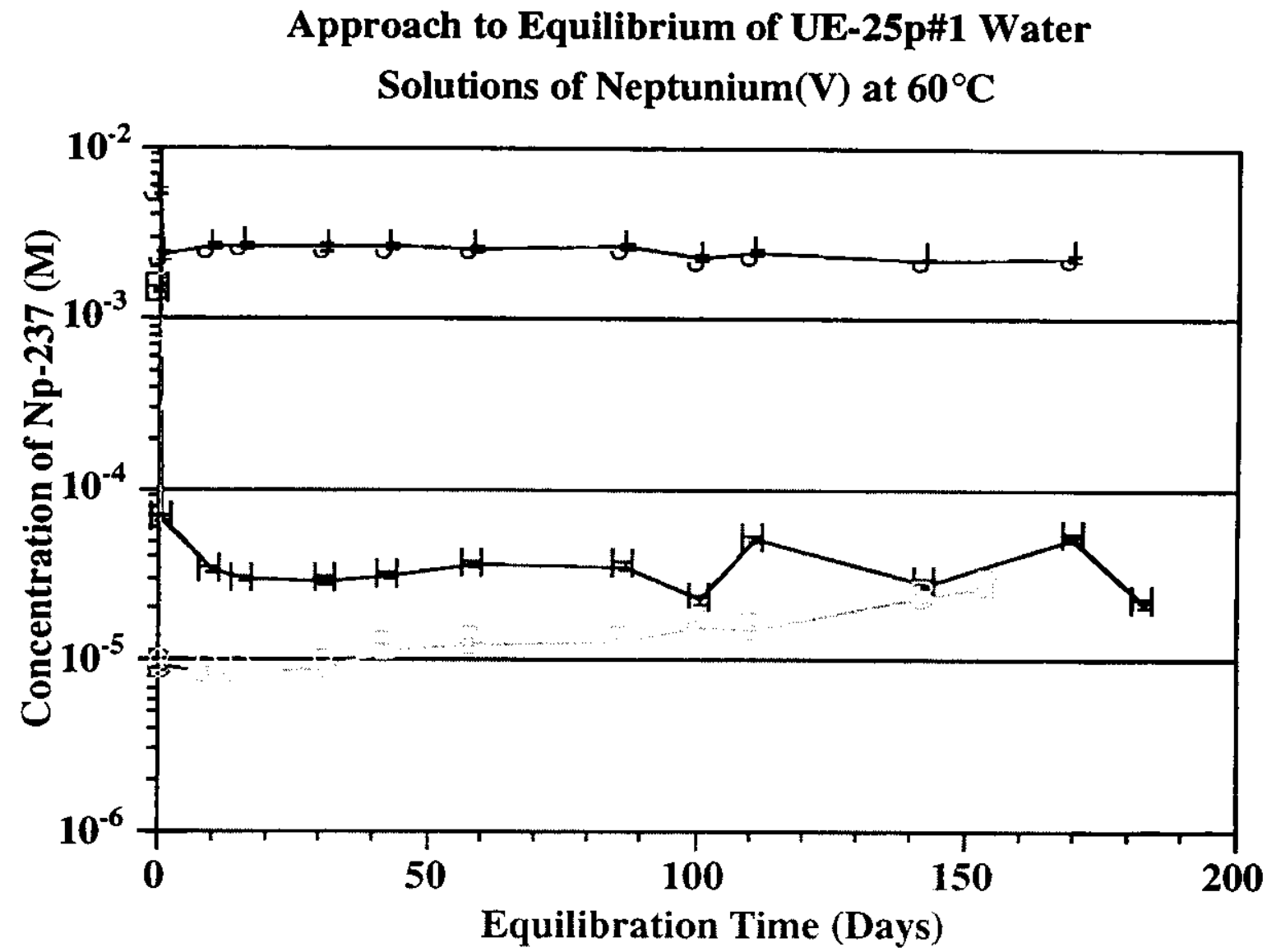

pH 6, Oversaturation

$+4 \mathrm{pH} \mathrm{7,} \mathrm{Oversaturation}$

pH 8.5, Oversaturation

Figure 3. Solution concentrations of ${ }^{237} \mathrm{~Np}$ in contact with precipitate obtained from supersaturation of UE-25p \#1 groundwater at $60^{\circ} \mathrm{C}$ as a function of time. $\mathrm{pH} 6.0 \pm 0.1$ (closed circles), $\mathrm{pH} 7.0 \pm 0.1$ (closed triangles), and $\mathrm{pH} 8.5 \pm 0.1$ (closed squares). The neptunium was added initially (day 0 ) as $\mathrm{NpO}_{2}{ }^{+}$; initial concentrations were $5.6 \times 10^{-3} \mathrm{M}(\mathrm{pH} 6), 1.5$ $\times 10^{-3} \mathrm{M}(\mathrm{pH} 7)$, and $1.5 \times 10^{-3} \mathrm{M}$ (pH 8.5). Undersaturation experiments at $\mathrm{pH} 6.0$ (open circles), $\mathrm{pH} 7.0$ (open triangles), and $\mathrm{pH} 8.5$ (open squares) were started with precipitates obtained in the supersaturation experiments at their respective $\mathrm{pH}$ values. 
Neptunium Filtration Experiments at pH 6, 7, and 8.5 in UE-25p\#1 Water Solutions at $25^{\circ} \mathrm{C}$

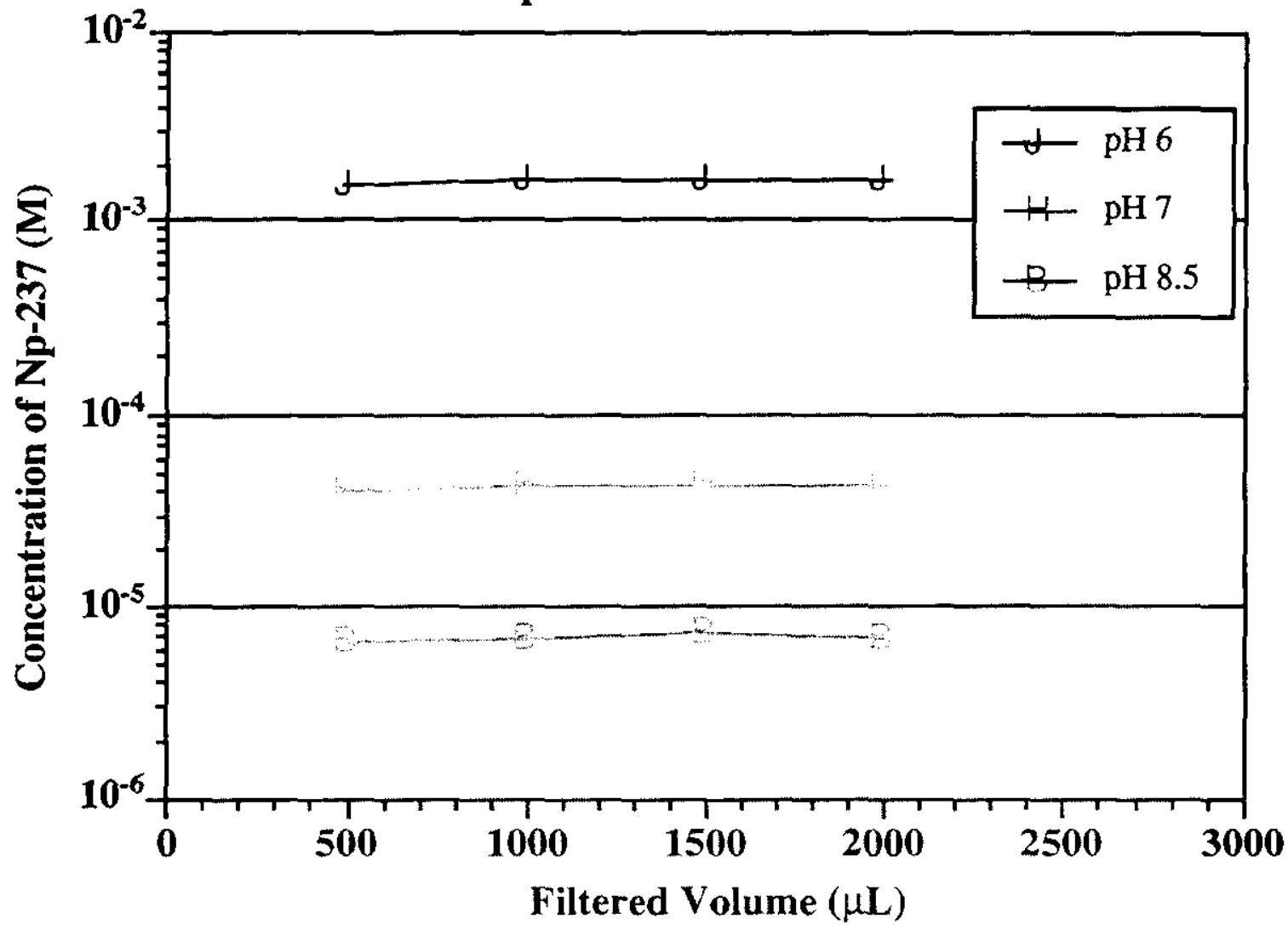

Figure 4. Results of Np filtration experiments at $25^{\circ} \mathrm{C}$ and $\mathrm{pH} 6,7$, and 8.5 conducted 100 days after the start of the experiments. 


\section{Neptunium Filtration Experiments at pH 6, 7, and 8.5 in UE-25p\#1 Water Solutions at $60^{\circ} \mathrm{C}$}

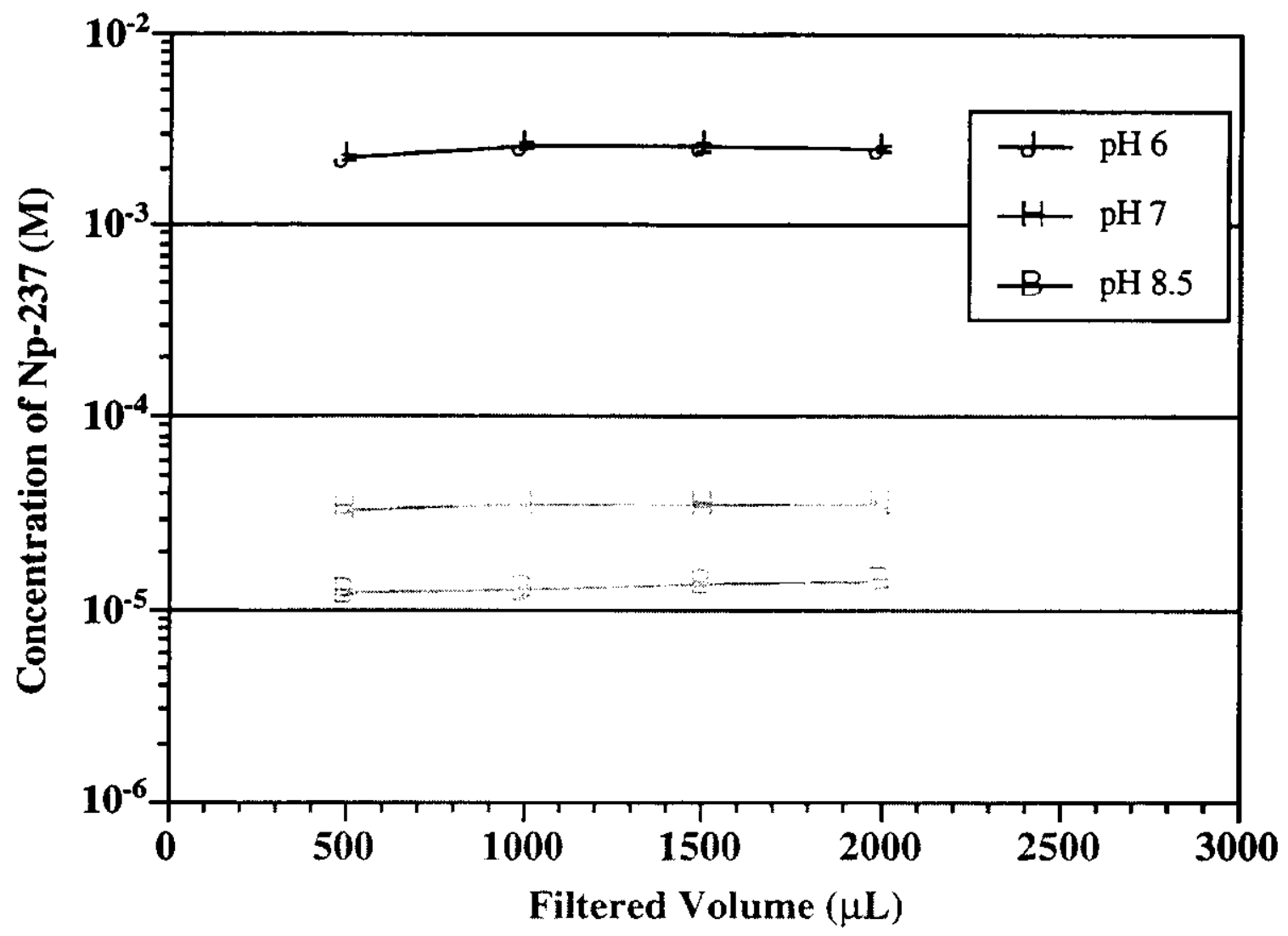

Figure 5. Results of $\mathrm{Np}$ filtration experiments at $60^{\circ} \mathrm{C}$ and $\mathrm{pH} 6,7$, and 8.5 conducted 87 days after the start of the experiments.

In summary, at each temperature, the neptunium solubility decreased with increasing $\mathrm{pH}$. At each $\mathrm{pH}$, the neptunium solubility decreased slightly with increasing temperature.

\subsubsection{Speciation}

The supernatant solutions from the neptunium solubility experiments were analyzed by absorption spectrophotometry to determine the oxidation state and speciation. The spectra for the $\mathrm{pH} 7$ experiment at $25^{\circ} \mathrm{C}$ are shown in Figure 6. The spectra for $60^{\circ} \mathrm{C}$ at pH 6,7, and 8.5 are shown in Figures 7,8 , and 9 , respectively. Solutions at $60^{\circ} \mathrm{C}$ underwent phase separation in a centrifuge heated to $60^{\circ}$ $\mathrm{C}$; however, the quartz cuvettes used for the spectral measurements were not thermostated. Even though spectral measurements were made immediately after the separation, the supernatant solutions may have cooled slightly before finishing the measurements. Depending on the $\mathrm{pH}$, the spectra show either the $\mathrm{NpO}_{2}{ }^{+}$main absorption band at $980.6 \mathrm{~nm}$ and/or anadditional band at $991 \mathrm{~nm}$ that increases with 
$\mathrm{pH}$ due to the increasing carbonate complexation. The band at $980.6 \mathrm{~nm}$ is characteristic of uncomplexed $\mathrm{NpO}_{2}{ }^{+}$. The band at $991 \mathrm{~nm}$ was established by Nitsche et al. ${ }^{29}$ It is typical for neptunyl(V) carbonate complexation.

To show that the band at $991 \mathrm{~nm}$ was indeed due to neptunyl(V) complexation by carbonate, we acidified the solutions to liberate the carbonate as carbon dioxide. After each solution was acidified with $\mathrm{HClO}_{4}$ to $\mathrm{pH} 0$, the absorption band at $991 \mathrm{~nm}$ disappeared, and only the band at $980.6 \mathrm{~nm}$ was present because the neptunium(V) carbonate complex reverted to uncomplexed neptunium(V). Through this procedure, we established that all solutions contained neptunyl(V) carbonate complex(es) with the exception of the $\mathrm{pH} 6$ samples at $25^{\circ}$ and $60^{\circ} \mathrm{C}$. The spectrum of the sample at $\mathrm{pH} 6$ and $25^{\circ} \mathrm{C}$, which is not shown here, did not undergo any change upon acidification of the solution. We could not record an absorption spectrum for the $25^{\circ} \mathrm{C}$ sample at $\mathrm{pH} 8.5$ because the concentration was below the detection limit. For the solutions that provided absorption spectra, we determined the amount of neptunium present as carbonate complex from the difference between the total amount of neptunium in solution (determined by $\gamma$-spectroscopy) and the free $\mathrm{NpOS}(+, 2)$ determined from the $980.6 \mathrm{~nm}$ absorption peak. The results of our neptuniurn speciation study are summarized in Table VII.

We used a non-linear, least-squares peak fitting routine (Spectra Calc, Galactic Industries Corporation, Salem, New Hampshire) to deconvolute the three absorption spectra that showed carbonate complexation in order to determine the complex stoichiometry. The results for the spectrum from the $25^{\circ} \mathrm{C}$ experiment at $\mathrm{pH} 7$, shown in Figure 10, indicate that the spectrum is composed of only two peaks: one at $980.6 \mathrm{~nm}$ for the uncomplexed NpOS(+,2) and a second one at $991 \mathrm{~nm}$ for the NpOSDO5(2)COS(,3) complex. A third species, such as the NpOSDO5(2)(COSDO5(3))S(3-,2) complex, did not fit the spectrum. Deconvolution of the spectrum from the $60^{\circ} \mathrm{C}$ experiment at $\mathrm{pH} 7$ also showed only two species NpOS(+,2) and NpOSDO5(2)COS(-,3), and the 991-nm band for the 60" $\mathrm{CpH} 8.5$ experiment

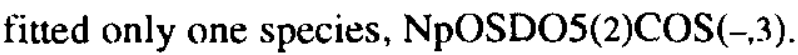




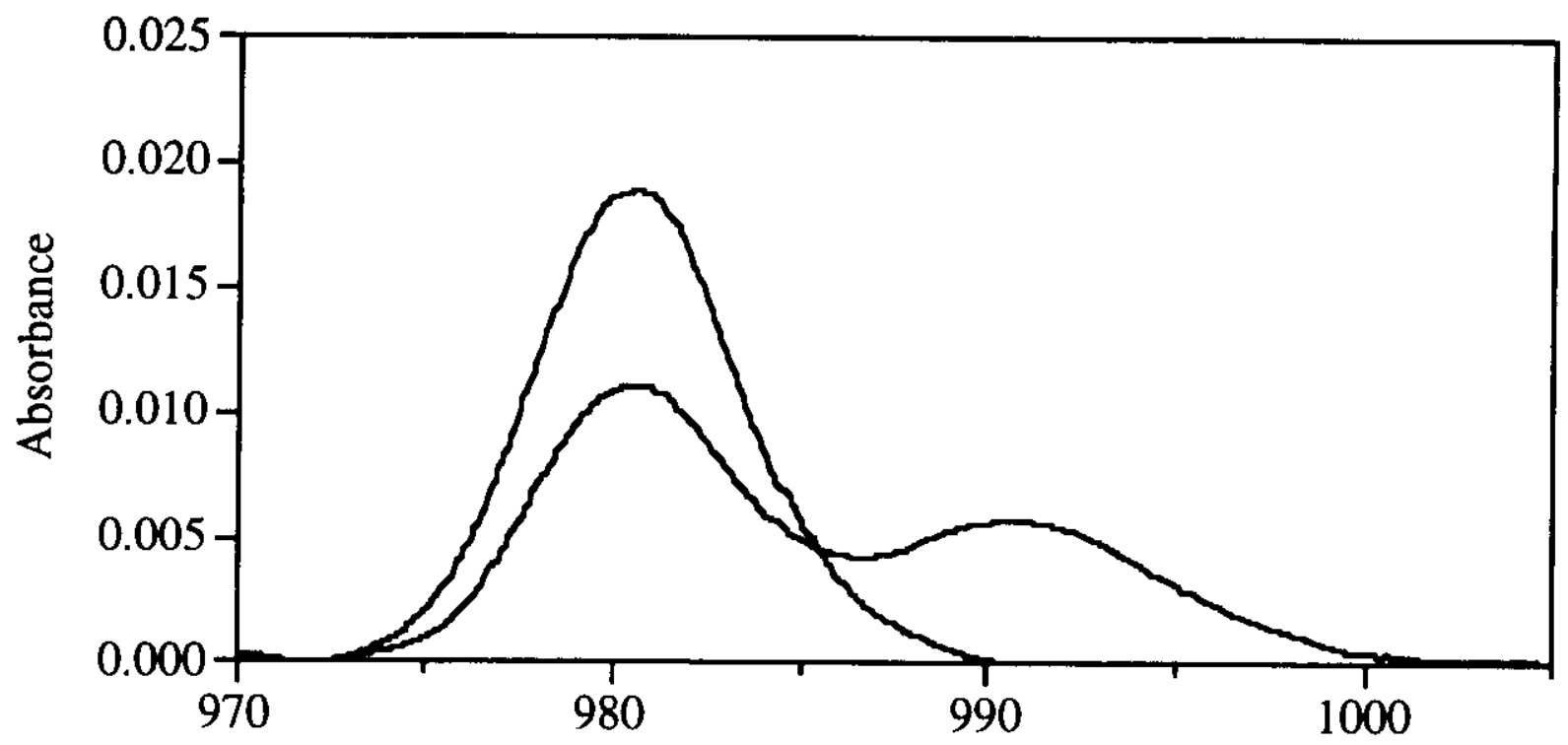

Figure 6. Near-IR absorption spectra of Np supernatant solutions at steady state formed in UE-25p \#1 groundwater at $25^{\circ} \mathrm{C}$ in $\mathrm{pH} 7.0:$ (1) at the experimental $\mathrm{pH}$ and (2) after acidification with $\mathrm{HClO}_{4}$ to $\mathrm{pH} 0$.

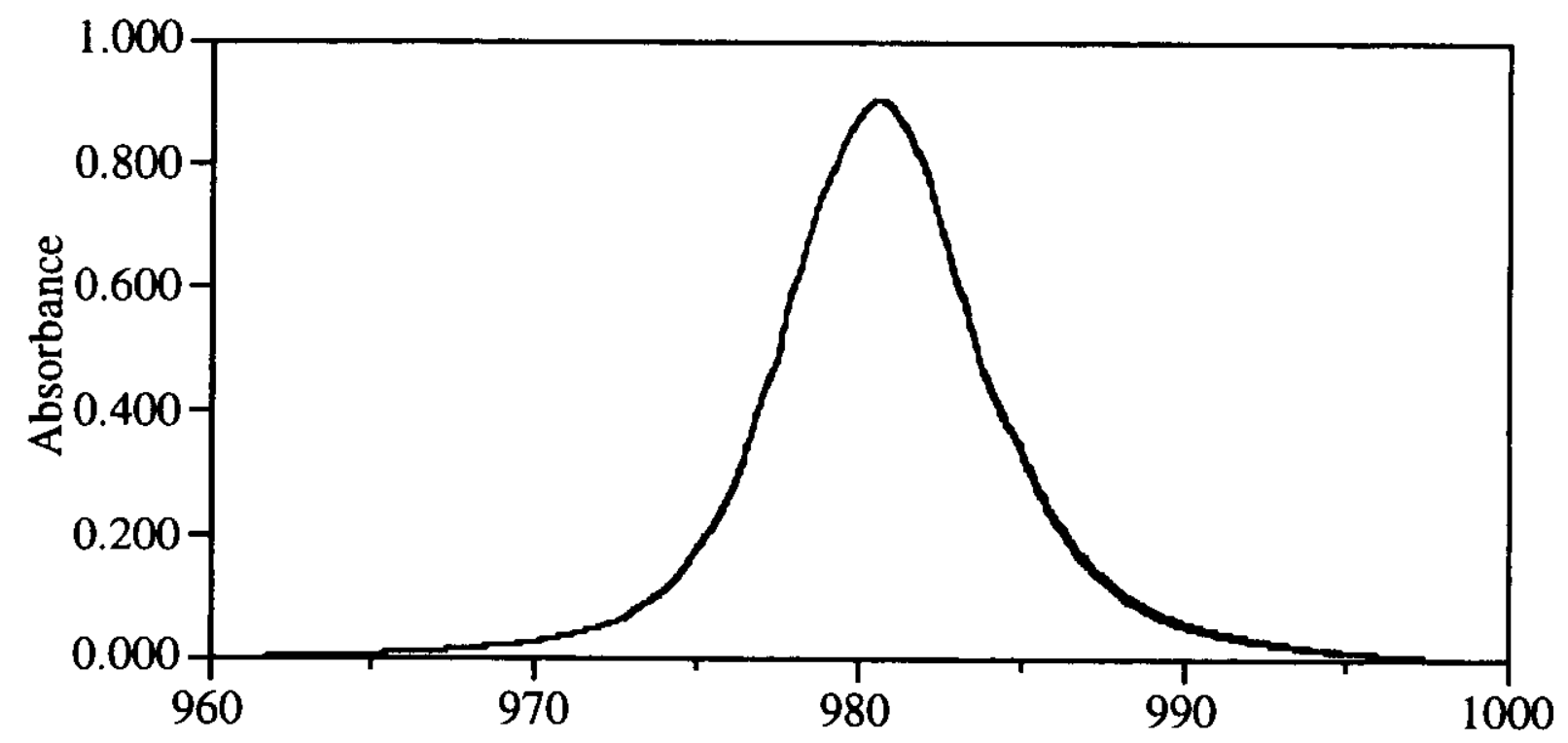

Figure 7. Near-IR absorption spectra of Np supernatant solutions at steady state formed in UE-25p \#1 groundwater at $60^{\circ} \mathrm{C}$ in $\mathrm{pH} 5.9:(1)$ at the experimental $\mathrm{pH}$ and (2) after acidification with $\mathrm{HClO}_{4}$ to $\mathrm{pH} 2$. 


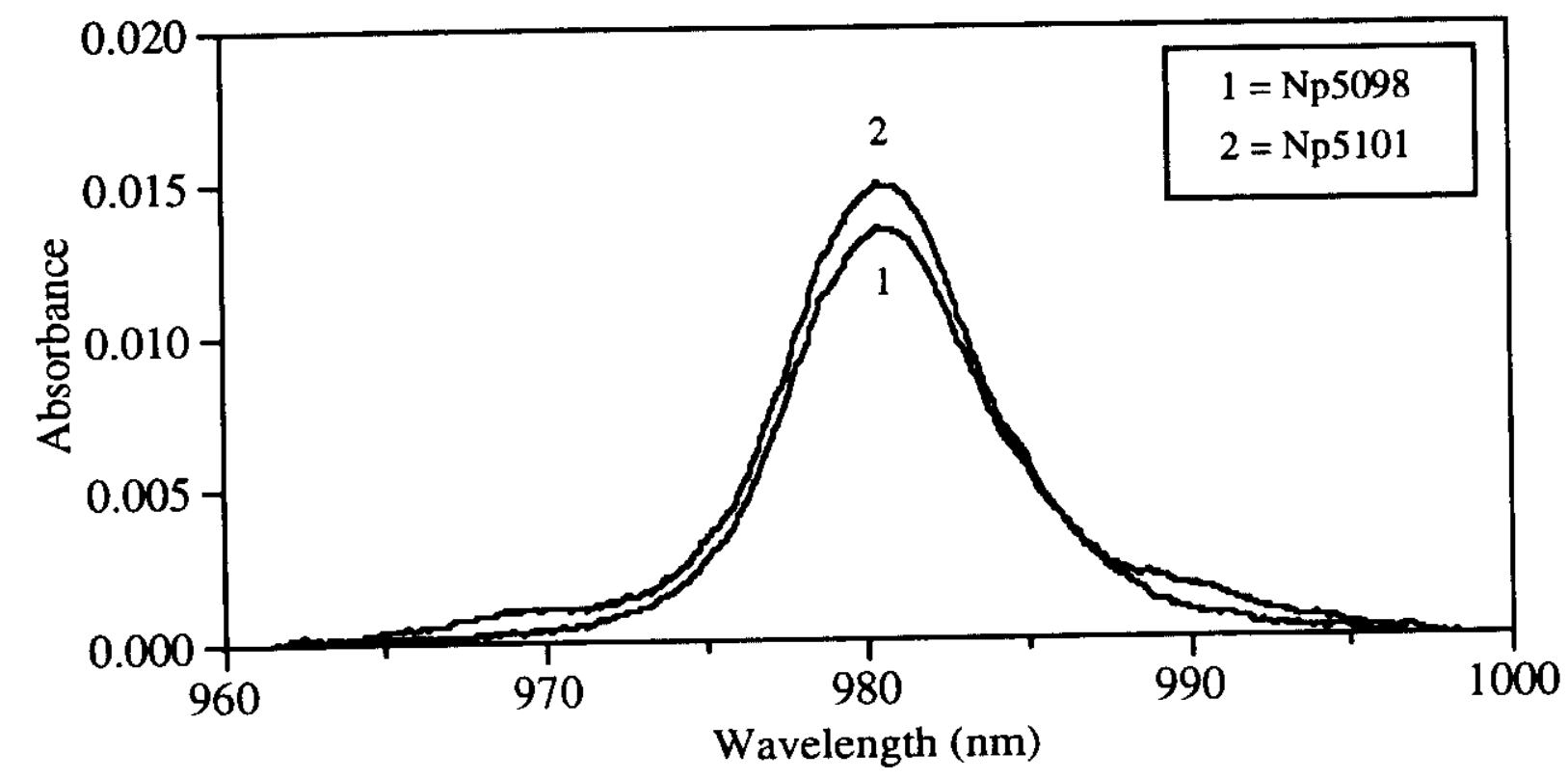

Figure 8. Near-IR absorption spectra of Np supernatant solutions at steady state formed in UE-25p \#1 groundwater at $60^{\circ} \mathrm{C}$ in $\mathrm{pH} 7.0:$ (1) at the experimental $\mathrm{pH} ;(2)$ after acidification with $\mathrm{HClO}_{4}$ to $\mathrm{pH} 1$.

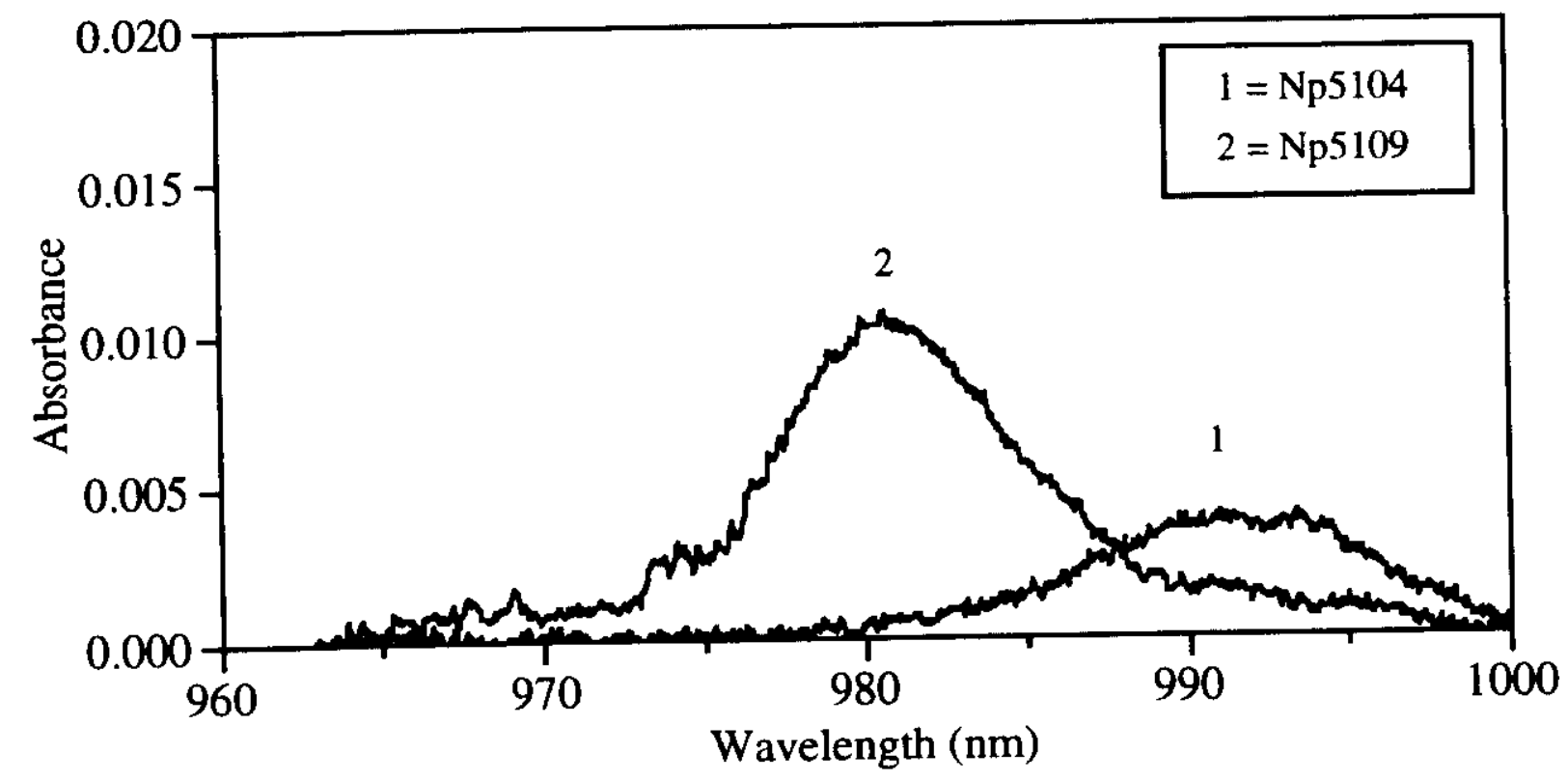

Figure 9. Near-IR absorption spectra of Np supernatant solutions at steady state formed in UE-25p \#1 groundwater at $60^{\circ} \mathrm{C}$ in $\mathrm{pH} 8.5:$ (1) at the experimental $\mathrm{pH} ;(2)$ after acidification with $\mathrm{HClO}_{4}$ to $\mathrm{pH} 1$. 
Table VII. Comparison of extent of carbonate complexation for steady state solutions of neptunium in UE-25p \#1 groundwater at $25^{\circ}$ and $60^{\circ} \mathrm{C}$.

\begin{tabular}{|c|c|c|c|c|}
\hline \multicolumn{5}{|c|}{ Neptunium Carbonate Complexation (\%) } \\
\hline \multirow{2}{*}{$\mathrm{pH}$} & \multicolumn{2}{|c|}{$25^{\circ} \mathrm{C}$} & \multicolumn{2}{c|}{$60^{\circ} \mathrm{C}$} \\
\cline { 2 - 5 } & $\mathrm{NpO}_{2}+$ & $\mathrm{NpO}_{2}\left(\mathrm{CO}_{3}\right)^{-}$ & $\mathrm{NpO}_{2}{ }^{+}$ & $\mathrm{NpO}_{2}\left(\mathrm{CO}_{3}\right)^{-}$ \\
\hline 6 & 100 & 0 & 100 & 0 \\
\hline 7 & 63 & 37 & 90 & 10 \\
\hline 8.5 & NA & NA & 0 & 100 \\
\hline
\end{tabular}

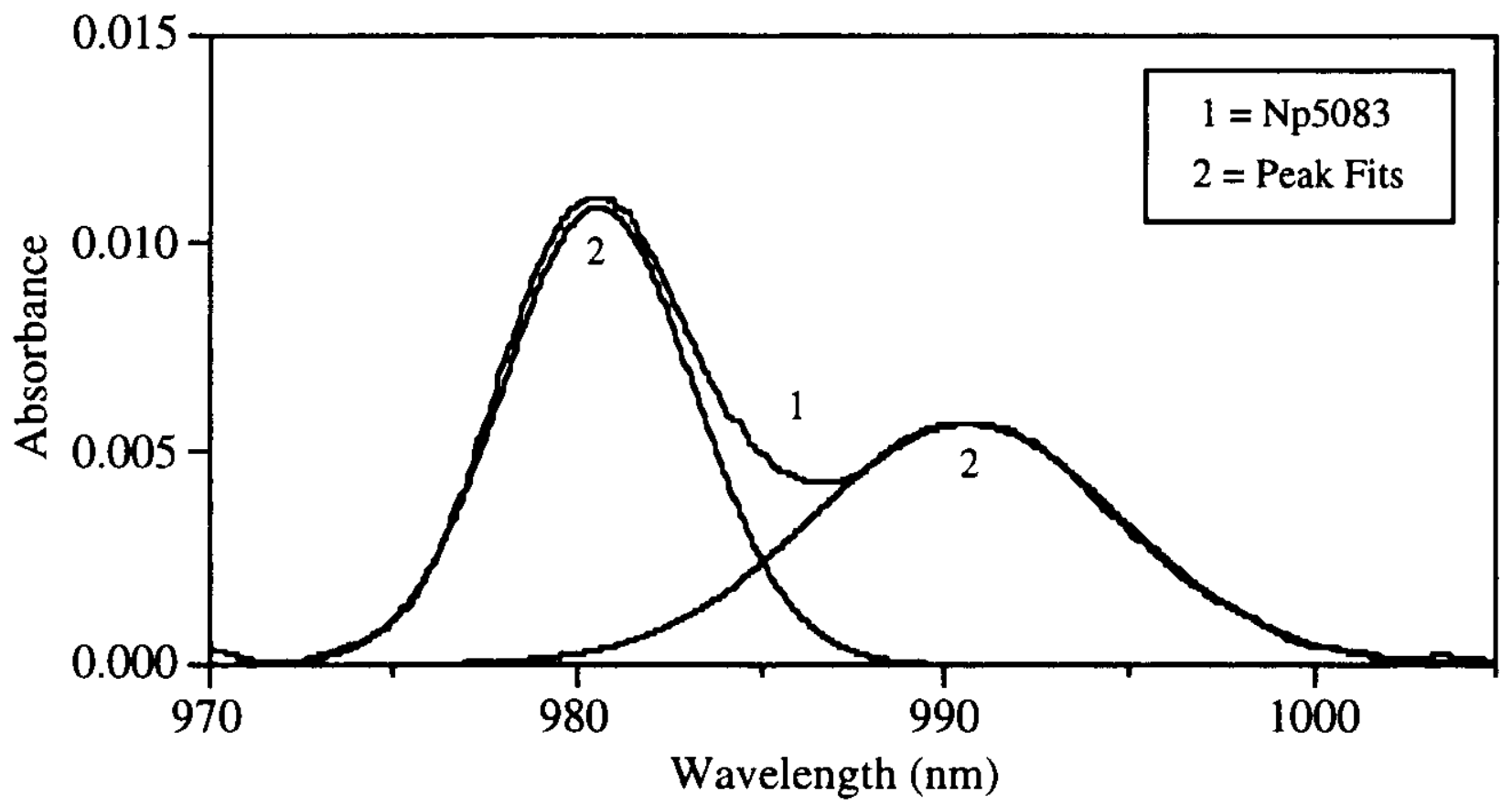

Figure 10. Deconvolution of the spectrum from the neptunium oversaturation experiment at $\mathrm{pH} 7$ and $25^{\circ} \mathrm{C}$ showing the two deconvoluted peaks at 980.6 and $991 \mathrm{~nm}$. 


\subsubsection{Identification of Solids}

The precipitates formed in the neptunium solutions were collected by centrifugation, washed with a small amount of $\mathrm{CO}_{2}$-free water, and dried with an argon jet. When wet, all precipitates were a very faint green color; however, when completely dry, they all became white crystalline solids. X-ray powder diffraction patterns taken from precipitates produced distinct lines; $d$-spacings and relative intensities are listed in Tables VIII, IX, and X for $25^{\circ}$ and $60^{\circ} \mathrm{C}$.

All of the solids obtained from the $60^{\circ} \mathrm{C}$ experiments agreed well with the solids obtained in the $25^{\circ} \mathrm{C}$ experiments. At each $\mathrm{pH}$, we obtained more diffraction lines per powder pattern at $25^{\circ} \mathrm{C}$ than we obtained from the respective $60^{\circ} \mathrm{C}$ solids. This is probably the result of shorter exposure times for the $60^{\circ} \mathrm{C}$ solids thus resulting in fewer "weak" and "trace" lines. The powder pattern of the $60^{\circ} \mathrm{C}$ precipitate at pH 5.9 fits 18 of 26 lines within $0.01 \AA$ when compared with the powder pattern of the $25^{\circ} \mathrm{C}$ precipitate at pH 5.9; all of the lines fit to within $0.03 \AA$. Twelve out of the 14 lines in $60^{\circ} \mathrm{C}$ precipitate at pH $7 \mathrm{fit}$ the $25^{\circ} \mathrm{C}$ precipitate to within $0.03 \AA$. The thirteenth line fit within $0.05 \AA$. The fourteenth line was a weak line not found in the $25^{\circ} \mathrm{C}$ powder pattern at $\mathrm{pH}$. The powder pattern obtained from the $60^{\circ} \mathrm{C}$ precipitate at $\mathrm{pH} 8.5$ matched 20 out of 21 lines found in the precipitate from the $25^{\circ} \mathrm{C}$ and $\mathrm{pH} 8.5$ experiment to within $0.04 \AA$. Here again, the twenty-first line was a trace line not found in the $25^{\circ} \mathrm{C}$ solid.

Sixteen of 21 lines in the $60^{\circ} \mathrm{C}$ precipitate at $\mathrm{pH} 8.5$ fit the $25^{\circ} \mathrm{C}$ precipitate at $\mathrm{pH} 5.9$ to within $0.01 \AA$. Again, all of the lines fit to within $0.03 \AA$. The $60^{\circ} \mathrm{C}$ precipitate at pH 7.0 fit both the $25^{\circ} \mathrm{C}$ precipitates at pH 5.9 and 7.0 but in both cases not as well as the $\mathrm{pH} 5.9$ and 8.5 samples. The $60^{\circ} \mathrm{C}$ precipitate at $\mathrm{pH} 7.0$ fit 8 of 14 lines with the $25^{\circ} \mathrm{C}$ precipitate at $\mathrm{pH} 6.0$ within a tolerance of $0.01 \AA$. It fit 11 of 14 lines to within $0.03 \AA$. The fit with the $25^{\circ} \mathrm{C}$ precipitate at pH 7.0 was nearly as good. Nine of the 14 lines fit to within $0.01 \AA$, and 11 of 14 lines fit to within $0.03 \AA$.

In comparing all of the powder patterns, we found that 22 lines were common in all six patterns (20 matched within $0.03 \AA$, one matched within $0.05 \AA$, and the last matched within $0.07 \AA$ ). The relative intensities of most of these lines also agreed with the understanding that all line intensities were visually estimated, so some degree of differing relative intensity should be and was expected.

A comparison of the $25^{\circ} \mathrm{C}$ solids with the published pattern of $\mathrm{Na}_{0.6} \mathrm{NpO}_{2}\left(\mathrm{CO}_{3}\right)_{0.8} \cdot 2.5 \mathrm{H}_{2} \mathrm{O}^{30}$ is given in Table XI. The d-spacings of the solids formed at $\mathrm{pH} 5.9, \mathrm{pH} 7.0$, and $\mathrm{pH} 8.5$ agreed with dspacings of $\mathrm{Na}_{0.6} \mathrm{NpO}_{2}\left(\mathrm{CO}_{3}\right)_{0.8} \cdot 2.5 \mathrm{H}_{2} \mathrm{O}$ to varying degrees. In the $\mathrm{pH} 5.9$ solid, 19 of the 38 measured lines matched the reference pattern with a tolerance of $0.01 \AA$, and all lines of this pattern matched within $0.03 \AA$. For the $\mathrm{pH} 7.0$ solid, 7 of the 24 lines matched the pattern of $\mathrm{Na}_{0.6} \mathrm{NpO}_{2}\left(\mathrm{CO}_{3}\right)_{0.8} \cdot 2.5 \mathrm{H}_{2} \mathrm{O}$ within $0.01 \AA$, and 20 of the 24 lines within $0.03 \AA$. The $\mathrm{d}$-spacings for the $\mathrm{pH} 8.5$ solid agreed relatively well with the $\mathrm{Na}_{0.6} \mathrm{NpO}_{2}\left(\mathrm{CO}_{3}\right)_{0.8} \cdot 2.5 \mathrm{H}_{2} \mathrm{O} ; 15$ of the 22 measured lines matched within $0.03 \AA$, but only six matched within $0.01 \AA$.

A comparison of the $60^{\circ} \mathrm{C}$ solids with the published pattern of $\mathrm{Na}_{0.6} \mathrm{NpO}_{2}\left(\mathrm{CO}_{3}\right)_{0.8} \cdot 2.5 \mathrm{H}_{2} \mathrm{O}^{30}$ is given in Table XII. The X-ray diffraction patterns of solids formed at $60^{\circ} \mathrm{C}$ at $5.9, \mathrm{pH} 7.0$, and $\mathrm{pH}$ 8.5 agreed with the pattern of $\mathrm{Na}_{0.6} \mathrm{NpO}_{2}\left(\mathrm{CO}_{3}\right)_{0.8} \cdot 2.5 \mathrm{H}_{2} \mathrm{O}$; again, to varying degrees. Eighteen of the 
26 lines of the $\mathrm{pH} 5.9$ pattern matched to within $0.03 \AA$, and 5 matched to within $0.01 \AA$. The pH 7.0 solid matched 8 of 14 lines to within $0.03 \AA$, but only matched 3 of 14 lines to within $0.01 \AA$. The pH 8.5 solid matched thirteen of 21 lines to within $0.03 \AA$, but only 4 of 21 lines matched to within a 0.01 Å tolerance.

The $\mathrm{pH} 5.9$ and $\mathrm{pH} 8.5$ solids at $60^{\circ} \mathrm{C}$ also matched the published pattern of $\mathrm{Na}_{3} \mathrm{NpO}_{2}\left(\mathrm{CO}_{3}\right)_{2}$. $\mathrm{n} \mathrm{H}_{2} \mathrm{O}^{31}$ relatively well. A comparison of the patterns can be found in Table XIII. The pH 5.9 solid matched 16 of 26 lines to within $0.03 \AA$, and 5 of 26 lines to within $0.01 \AA$. The pH 8.5 solid matched 12 of 21 lines to within $0.03 \AA$, and only 4 of 21 lines to within $0.01 \AA$. However, it should be noted that the strongest lines in both the $\mathrm{pH} 5.9$ and $\mathrm{pH} 8.5$ samples did not fit the $\mathrm{Na}_{3} \mathrm{NpO}_{2}\left(\mathrm{CO}_{3}\right)_{2} \cdot \mathrm{n} \mathrm{H}_{2} \mathrm{O}$ solid as well as the $\mathrm{Na}_{0.6} \mathrm{NpO}_{2}\left(\mathrm{CO}_{3}\right)_{0.8} \cdot 2.5 \mathrm{H}_{2} \mathrm{O}$ solid.

Based on the visual comparisons and the similarity in the $x$-ray powder diffraction patterns, the solids obtained at all three $\mathrm{pH}$ values and at both temperatures are at least very similar, if not identical. Although a few lines in our powder patterns differ from those in the literature, all of the solids we obtained apparently contain ternary sodium neptunium carbonate hydrates of different stoichiometry and/or water content. Many of the corresponding solids described in the literature are metastable, difficult to reproduce, and show the extent to which line spacings vary. ${ }^{30,31,32,33}$ There is also the possibility that other mineral solids may have formed because of the other constituents in UE-25p \#1 groundwater, but with the predominance of sodium in the groundwater accompanied by the high carbonate content, the primary solids obtained were of the sodium neptunium(V) carbonate type.

The solubility decrease with increasing $\mathrm{pH}$ is clearly connected to the formation of carbonate containing solids. As the $\mathrm{pH}$ increased in UE-25p \#1, the increased free carbonate in solution precipitated more of the aqueous neptunium resulting in a lower neptunium solubility. This is simply the pH effect on the solubility of a carbonate containing solid in solution. Since there are such discrepancies in the line spacings for the various powder patterns of ternary sodium neptunium carbonates in the literature, we suggest that a detailed study of these solids be performed, so that these differences can be clearly explained. We also suggest measuring the solubility of defined ternary neptunium carbonate solids as a function of solution $\mathrm{pH}$ in order to obtain the solubility products required for modeling calculations. 
Table VIII. $\mathrm{X}$-ray powder diffraction patterns of neptunium solid phases in UE-25p \#1 groundwater at $25^{\circ}$ and $60^{\circ} \mathrm{C}$ and $\mathrm{pH} 5.9$.

\begin{tabular}{|c|c|c|c|}
\hline \multicolumn{2}{|c|}{$25^{\circ} \mathrm{C}$} & \multicolumn{2}{|c|}{$60^{\circ} \mathrm{C}$} \\
\hline $\mathrm{d}(\AA \AA)$ & $I^{a}$ & $d(\AA)$ & $I^{\mathrm{a}}$ \\
\hline 9.36 & S & 9.41 & VS \\
\hline 4.86 & m- & 4.87 & $\mathbf{m}$ \\
\hline 4.67 & s- & 4.70 & $\mathbf{S}$ \\
\hline 4.33 & $s$ & 4.34 & $s$ \\
\hline 3.93 & s- & 3.93 & s- \\
\hline 3.56 & $t$ & & \\
\hline 3.40 & w & 3.40 & $t$ \\
\hline 3.24 & $\mathrm{~m}$ & 3.26 & m \\
\hline 3.15 & $w$ & 3.15 & $\mathbf{w}$ \\
\hline 3.05 & $\mathrm{~m}$ & 3.07 & $\mathbf{s}$ \\
\hline 2.88 & $t$ & & \\
\hline 2.67 & $\mathrm{~m}$ & 2.67 & $\mathrm{~m}$ \\
\hline 2.54 & $w$ & 2.55 & $\mathbf{w}$ \\
\hline 2.43 & $w$ & 2.43 & $w$ \\
\hline 2.36 & $w$ & 2.36 & $\mathrm{~m}$ \\
\hline 2.25 & w- & 2.25 & $t$ \\
\hline 2.17 & w- & 2.17 & $t$ \\
\hline 2.12 & $\mathrm{~m}$ & 2.12 & $\mathbf{m}$ \\
\hline 2.07 & $w$ & 2.07 & w \\
\hline 1.98 & $\mathrm{~m}$ & 1.97 & $t$ \\
\hline 1.94 & $w$ & 1.93 & $w$ \\
\hline 1.90 & $\mathbf{t}$ & 1.90 & $\mathbf{t}$ \\
\hline 1.88 & $\mathrm{t}$ & 1.89 & $\mathbf{t}$ \\
\hline 1.76 & $w$ & 1.76 & $\mathbf{w +}$ \\
\hline 1.73 & $\mathrm{t}$ & & \\
\hline 1.69 & $t$ & & \\
\hline 1.67 & $\mathfrak{t}$ & & \\
\hline 1.62 & $t$ & 1.62 & $t$ \\
\hline 1.60 & $\mathbf{t}$ & 1.60 & $\mathrm{t}$ \\
\hline 1.57 & $t$ & 1.57 & $\mathbf{t}$ \\
\hline 1.52 & $t$ & & \\
\hline 1.49 & $\mathrm{t}$ & & \\
\hline 1.44 & $t$ & & \\
\hline 1.41 & $\mathrm{t}$ & & \\
\hline 1.39 & $\mathrm{t}$ & & \\
\hline 1.30 & $t$ & & \\
\hline 1.24 & $t$ & & \\
\hline 1.23 & $\mathrm{t}$ & & \\
\hline
\end{tabular}

(a) Relative intensities visually estimated: $v s=$ very strong, $\mathrm{s}=$ strong, $\mathrm{m}=$ medium, $\mathrm{w}=$ weak, $\mathrm{t}=$ trace. 
Table IX. X-ray powder diffraction patterns of neptunium solid phases in UE-25p \#1 groundwater at $25^{\circ}$ and $60^{\circ} \mathrm{C}$ and $\mathrm{pH} 7.0$.

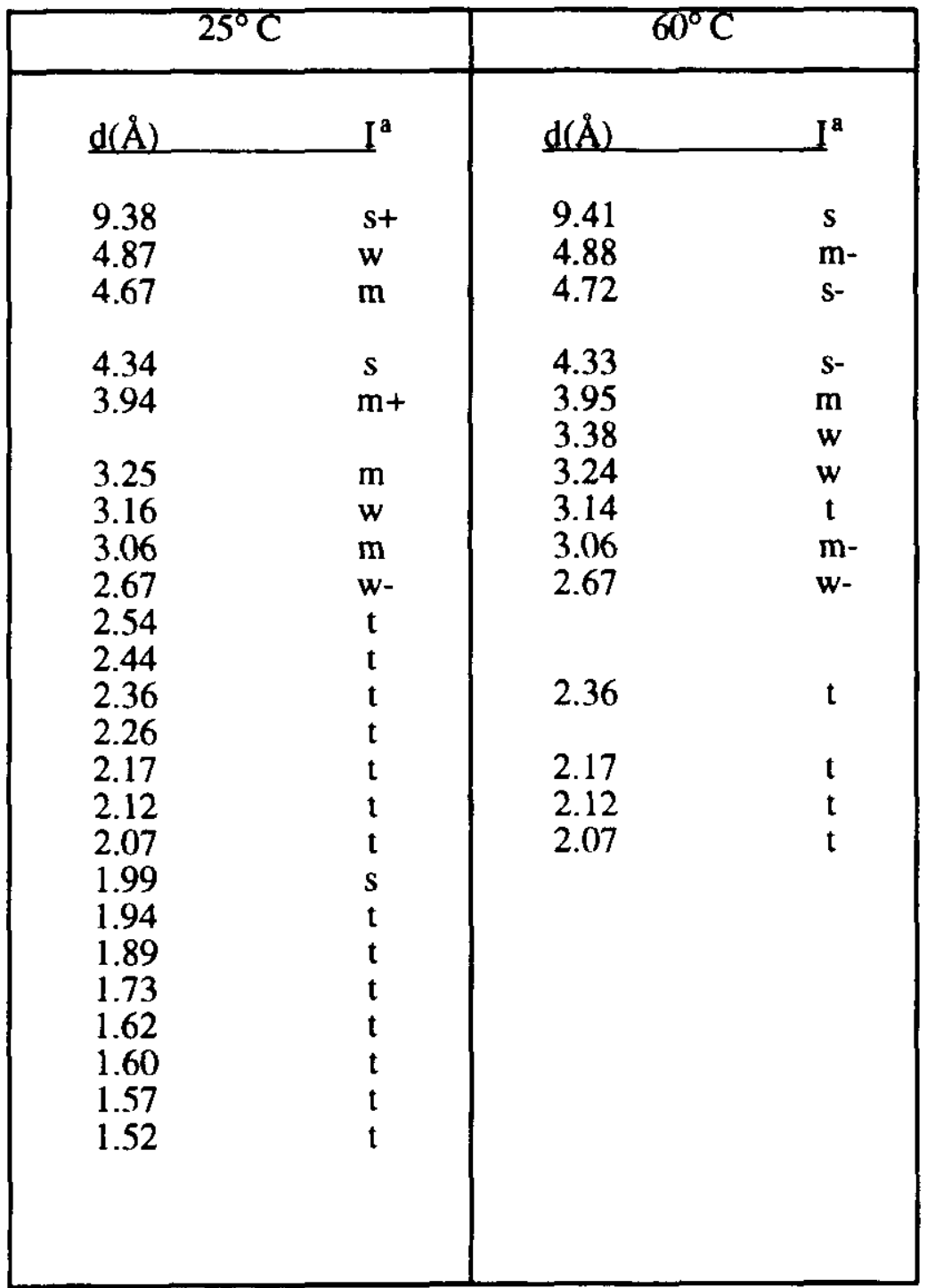

(a) Relative intensities visually estimated: $v s=$ very strong,

$s=$ strong, $m=$ medium, $w=$ weak, $t=$ trace. 
Table X. X-ray powder diffraction patterns of neptunium solid phases in UE-25p \#1 groundwater at $25^{\circ}$ and $60^{\circ} \mathrm{C}$ and $\mathrm{pH} 8.5$.

\begin{tabular}{|c|c|c|c|}
\hline \multicolumn{2}{|c|}{$25^{\circ} \mathrm{C}$} & \multicolumn{2}{|c|}{$60^{\circ} \mathrm{C}$} \\
\hline $\mathrm{d}(\AA \AA)$ & $I^{\mathrm{a}}$ & $\mathrm{d}(\AA)$ & $\mathrm{I}^{\mathrm{a}}$ \\
\hline 9.41 & S & 9.43 & $s$ \\
\hline 4.86 & m- & 4.86 & $\mathbf{w}$ \\
\hline 4.70 & $\mathrm{mt}$ & 4.70 & $S$ \\
\hline 4.32 & $\mathrm{~m}+$ & 4.33 & $\mathbf{s}$ \\
\hline 3.92 & $\mathrm{~m}$ & 3.93 & s- \\
\hline 3.34 & $t+$ & 3.38 & $\mathbf{w}$ \\
\hline 3.23 & $w+$ & 3.25 & wt \\
\hline 3.13 & $\mathbf{w}$ & 3.15 & w \\
\hline 3.05 & $w+$ & 3.06 & $\mathbf{s}$ \\
\hline 2.66 & w- & 2.68 & $w$ \\
\hline 2.53 & $t$ & 2.54 & $t$ \\
\hline 2.42 & $w-$ & 2.44 & $\mathbf{t}$ \\
\hline 2.35 & w- & 2.36 & w- \\
\hline 2.26 & $\mathrm{t}$ & & \\
\hline 2.16 & $w-$ & 2.16 & $\mathrm{t}$ \\
\hline 2.12 & $\mathbf{w}$ & 2.12 & $w$ \\
\hline 2.07 & $w-$ & 2.08 & $w$ \\
\hline 1.99 & $\mathrm{~m}$ & 1.97 & $t$ \\
\hline 1.94 & w- & 1.94 & $\mathrm{t}$ \\
\hline & & 1.90 & $t$ \\
\hline 1.88 & $t$ & 1.89 & $\mathrm{t}$ \\
\hline 1.73 & w & 1.76 & $w$ \\
\hline 1.62 & $t$ & & \\
\hline
\end{tabular}

(a) Relative intensities visually estimated: $v s=$ very strong, $\mathrm{s}=$ strong, $\mathrm{m}=$ medium, $\mathrm{w}=$ weak, $\mathrm{t}=$ trace . 
Table XI. X-ray powder diffraction patterns of neptunium solid phases in UE-25p \#1 groundwater at $25^{\circ} \mathrm{C}$, pH 5.9, $\mathrm{pH} 7.0$, and $\mathrm{pH} 8.5$ compared with the pattern of $\mathrm{Na}_{0.6} \mathrm{NpO}_{2}\left(\mathrm{CO}_{3}\right)_{0.8}$. $2.5 \mathrm{H}_{2} \mathrm{O} .{ }^{30}$

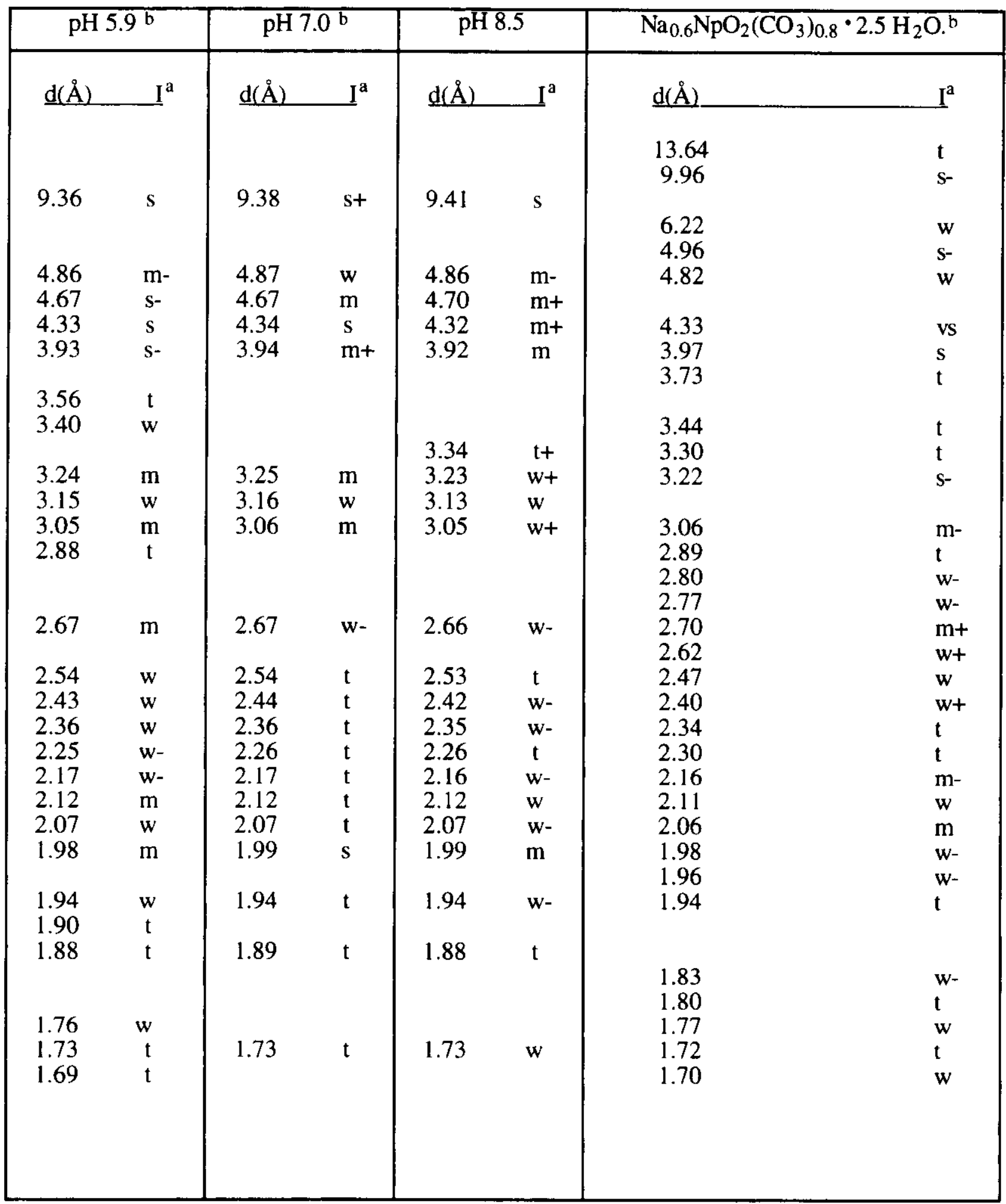

(a) Relative intensities visually estimated: $v s=$ very strong, $s=$ strong, $m=$ medium, $w=$ weak, $t=$ trace (b) The $\mathrm{pH} 5.9$ pattern and the $\mathrm{pH} 7.0$ pattern have an additional 12 lines (t) and 4 lines ( $\mathrm{t}$ ) respectively, not listed here, ranging from $1.67 \AA$ to $1.23 \AA$. The $\mathrm{Na}_{0.6} \mathrm{NpO}_{2}\left(\mathrm{CO}_{3}\right)_{0.8} \cdot 2.5 \mathrm{H} 2 \mathrm{O}$ reference pattern has an additional 27 lines $(w$ and $t)$ not listed here, ranging from $1.70 \AA$ to $1.11 \AA$. 
Table XII. X-ray powder diffraction patterns of neptunium solid phases in UE-25p \#1 groundwater at $60^{\circ} \mathrm{C}, \mathrm{pH} 5.9, \mathrm{pH} 7.0$, and $\mathrm{pH} 8.5$ compared with the pattern of $\mathrm{Na}_{0.6} \mathrm{NpO}_{2}\left(\mathrm{CO}_{3}\right)_{0.8}{ }^{\circ}$ $2.5 \mathrm{H}_{2} \mathrm{O} .{ }^{30}$

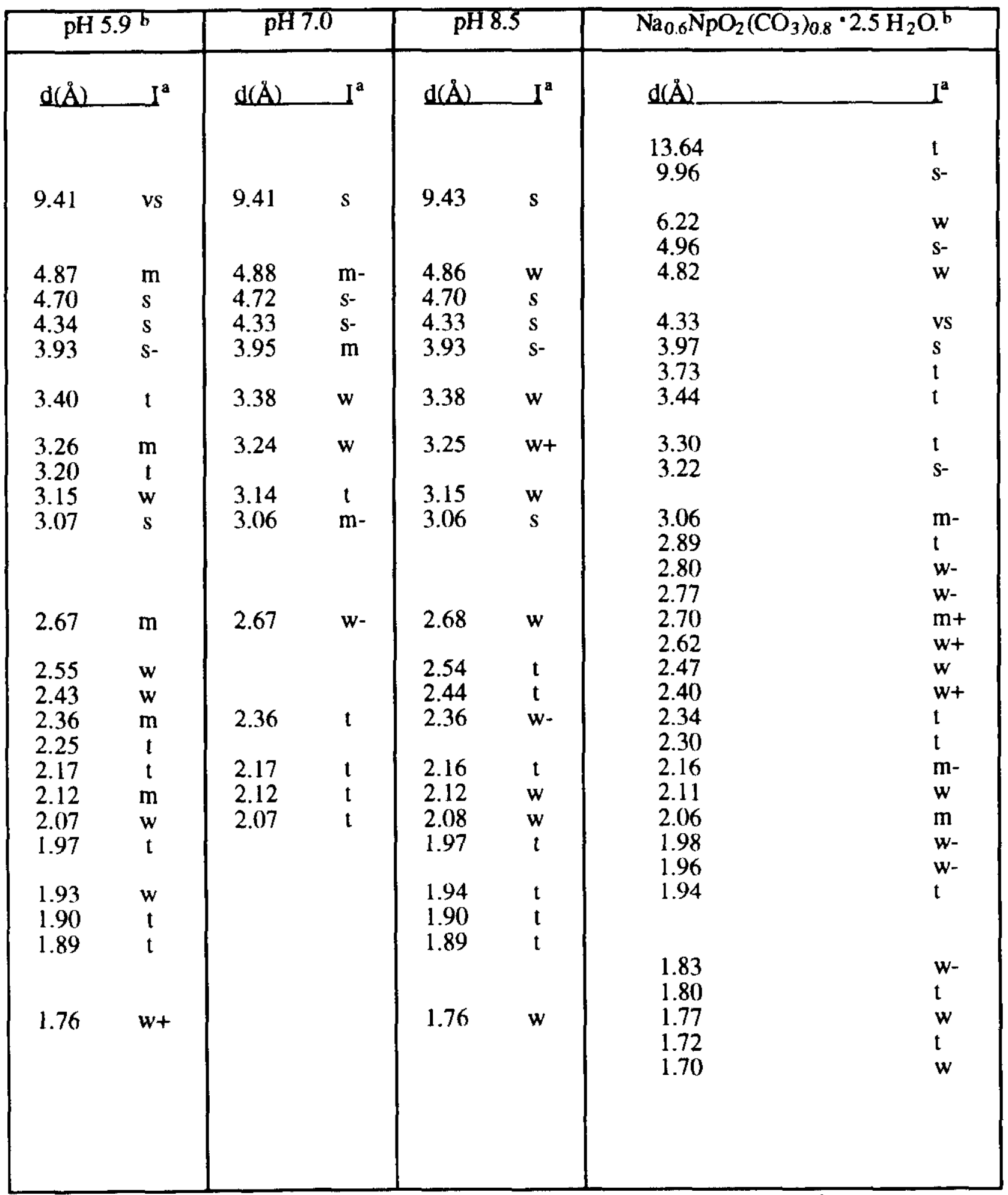

(a) Relative intensities visually estimated: $v s=$ very strong, $s=$ strong, $m=$ medium, $w=$ weak, $t=$ trace

(b) The pH 5.9 pattern has an additional 3 lines ( $t$ ) not listed here, ranging from $1.62 \AA$ to $1.57 \AA$. The $\mathrm{Na}_{0.6} \mathrm{NpO}_{2}\left(\mathrm{CO}_{3}\right)_{0.8} \cdot 2.5 \mathrm{H}_{2} \mathrm{O}$ reference pattern has an additional 27 lines ( $\mathrm{w}$ and $\mathrm{t}$ ) not listed here, ranging from $1.70 \AA$ to $1.11 \AA$. 
Table XIII. X-ray powder diffraction patterns of neptunium solid phases in UE-25p \#1 groundwater at $60^{\circ}, \mathrm{pH} 5.9, \mathrm{pH} 7.0$, and $\mathrm{pH} 8.5$ compared with the pattern of $\mathrm{Na}_{3} \mathrm{NpO}_{2}\left(\mathrm{CO}_{3}\right)_{2} \cdot \mathrm{nH}_{2} \mathrm{O} .{ }^{31}$

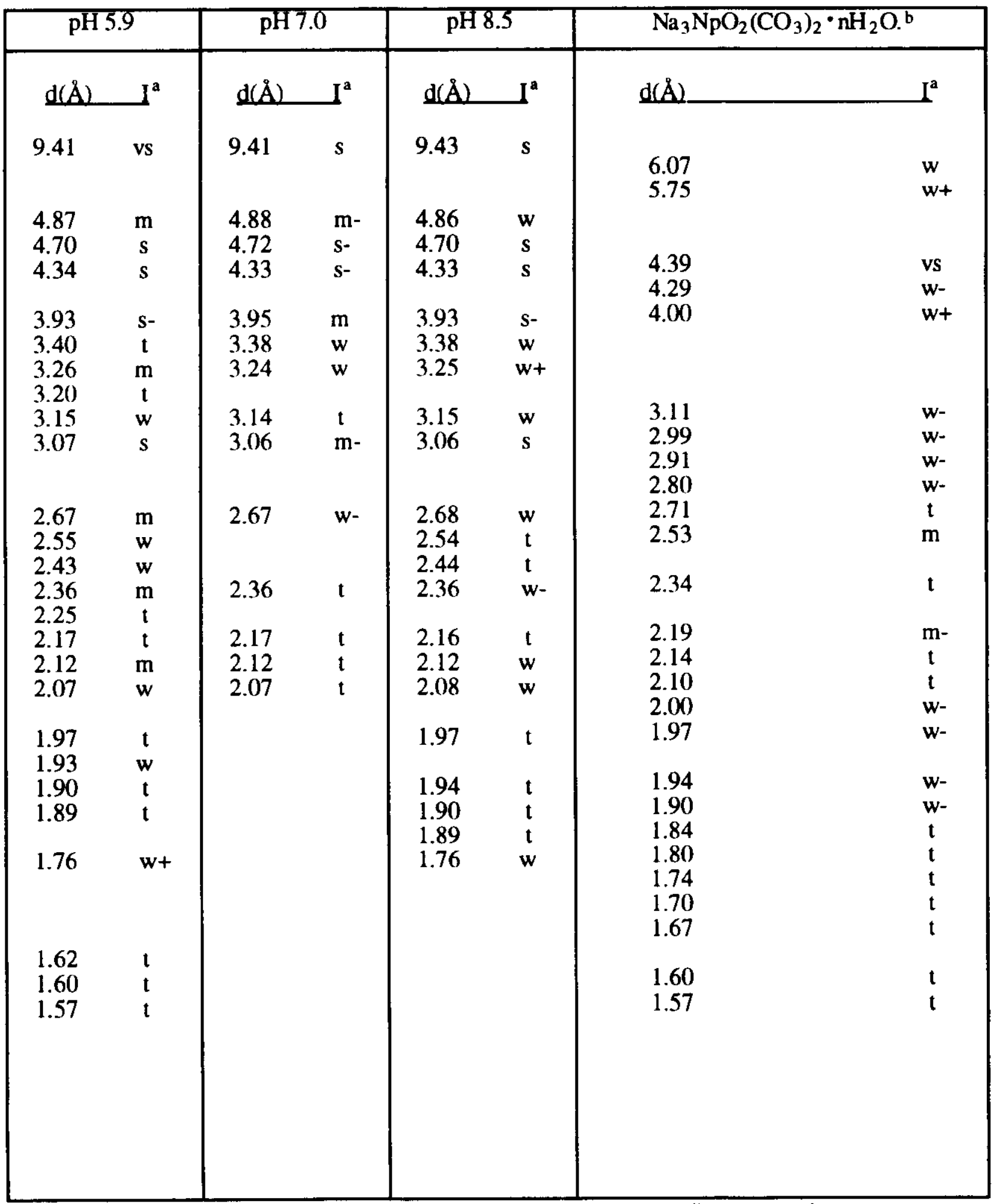

(a) Relative intensities visually estimated: $v s=$ very strong, $s=$ strong, $m=$ medium, $w=$ weak, $t=$ trace

(b) The $\mathrm{Na}_{3} \mathrm{NpO}_{2}\left(\mathrm{CO}_{3}\right)_{2} \cdot \mathrm{nH}_{2} \mathrm{O}$ reference pattern has an additional 8 lines $(t)$ not listed here, ranging from $1.54 \AA$ to $1.27 \AA$. 


\subsection{Plutonium}

\subsubsection{Solubility}

Results of the plutonium solubility studies are shown in Figure 11. The plutonium was initially introduced as $\mathrm{Pu}^{4+}$ into the UE-25p \# 1 groundwater. The steady-state concentrations and the solutions' Eh values are given in Table XIV. Concentration profiles as a function of time and $\mathrm{pH}$ for $25^{\circ}$ and $60^{\circ}$ $\mathrm{C}$ are shown in Figures 12 and 13. The individual measurements are listed in Appendix B. Representative results from plutonium filtration experiments at $25^{\circ}$ and $60^{\circ} \mathrm{C}$ are shown in Figures in 14 and 15 , respectively. The filtration experiments are described in section 4.5 . We could not find any volume effect for the plutonium, so we used $500 \mu \mathrm{L}$ of solution as presaturation volume for routine separations.

\section{Plutonium(IV) Solubility Experiments in UE-25p\#1 Water at $25^{\circ}$ and $60^{\circ} \mathrm{C}$}

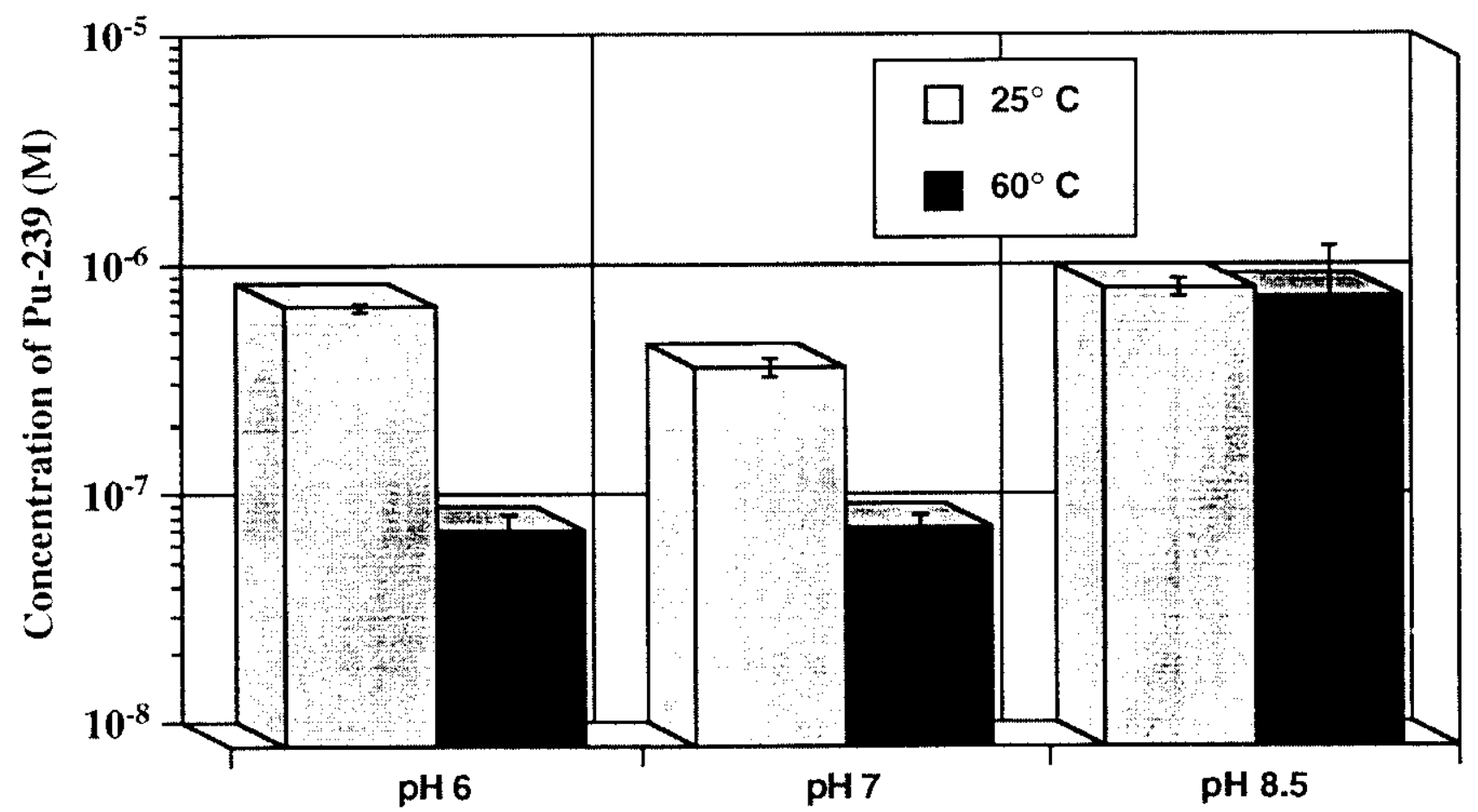

Figure 11. Results of the plutonium solubility experiments in UE-25p \#1 groundwater as a function of $\mathrm{pH}$ and temperature. 
Table XIV. Comparison of steady-state solution concentrations and Eh for plutonium in UE-25p \#1 water at $25^{\circ}$ and $60^{\circ} \mathrm{C}$.

\begin{tabular}{|c|c|c|c|c|}
\hline \multirow{2}{*}{$\mathrm{pH}$} & \multicolumn{4}{|c|}{ Plutonium(IV) } \\
\cline { 2 - 5 } & \multicolumn{3}{|c|}{ Concentration (M) } & \multicolumn{2}{|c|}{ Eh (mV vs. NHE) } \\
\cline { 2 - 5 } & $25^{\circ} \mathrm{C}$ & $60^{\circ} \mathrm{C}$ & $25^{\circ} \mathrm{C}$ & $60^{\circ} \mathrm{C}$ \\
\hline 6 & $(8.3 \pm 0.4) \times 10^{-7}$ & $(8.9 \pm 1.4) \times 10^{-8}$ & $(348 \pm 15)$ & $(326 \pm 15)$ \\
\hline 7 & $(4.5 \pm 0.4) \times 10^{-7}$ & $(9.1 \pm 1.2) \times 10^{-8}$ & $(282 \pm 15)$ & $(334 \pm 15)$ \\
\hline 8.5 & $(1.0 \pm 0.1) \times 10^{-6}$ & $(9.3 \pm 6.0) \times 10^{-7}$ & $(273 \pm 15)$ & $(231 \pm 15)$ \\
\hline
\end{tabular}

\section{Approach to Equilibrium of UE-25p\#1 Water Solutions of Plutonium(IV) at $25^{\circ} \mathrm{C}$}

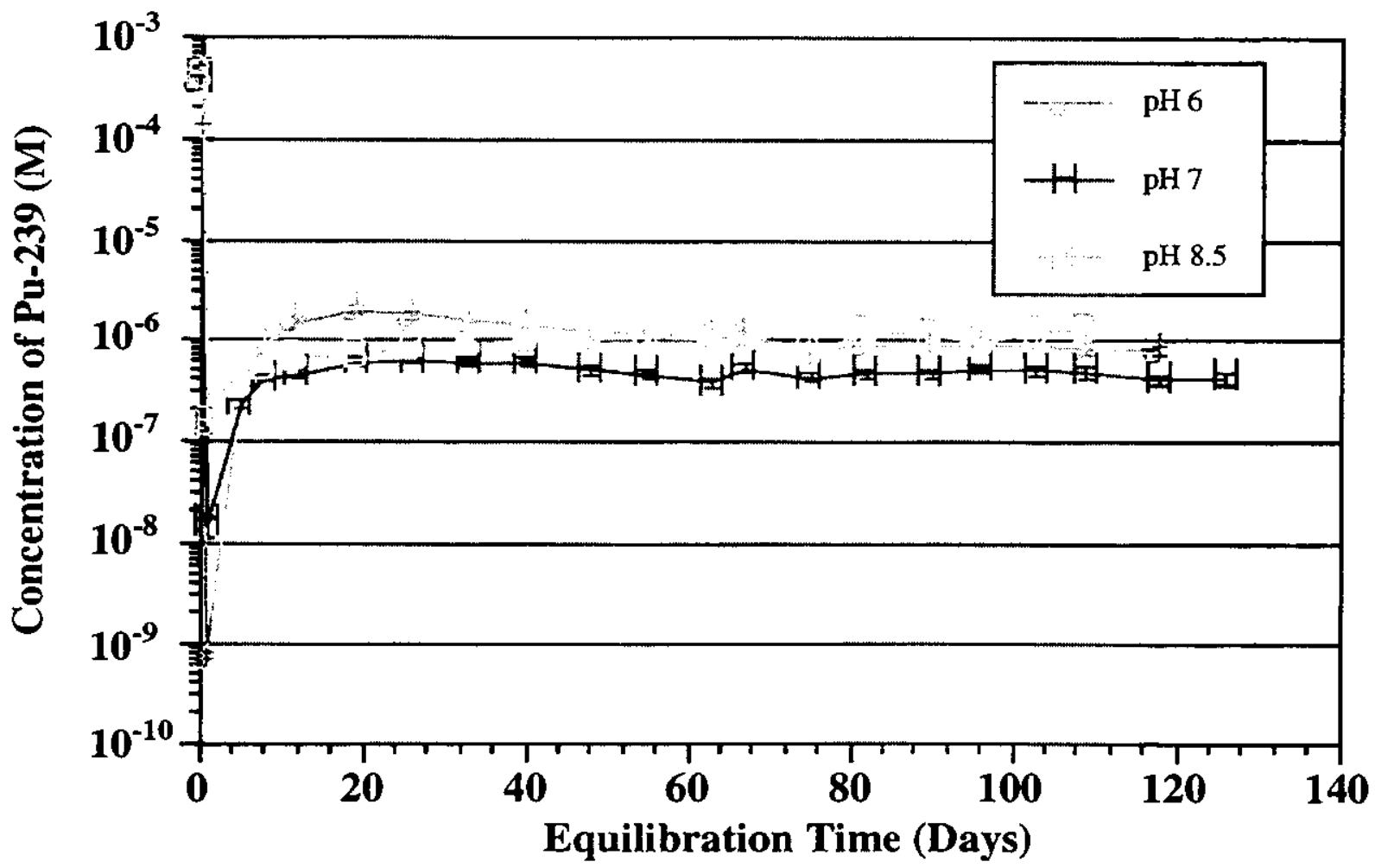

Figure 12. Solution concentrations of ${ }^{239} \mathrm{Pu}$ in contact with precipitate obtained from supersaturation of UE-25p \#1 groundwater at $25^{\circ} \mathrm{C}$ as a function of time. $\mathrm{pH} 6.0 \pm 0.1$ (closed circles), $\mathrm{pH} 7.0 \pm 0.1$ (closed triangles), and $\mathrm{pH} 8.5 \pm 0.1$ (closed squares). The plutonium was added initially (day 0 ) as $\mathrm{Pu}^{4+}$; initial concentrations were $3.8 \times 10^{-4} \mathrm{M}(\mathrm{pH} 6), 3.8$ $\times 10^{-4} \mathrm{M}(\mathrm{pH} 7)$, and $3.8 \times 10^{-4} \mathrm{M}(\mathrm{pH} 8.5)$. 


\section{Approach to Equilibrium of UE-25p\#1 Water \\ Solutions of Plutonium(IV) at $60^{\circ} \mathrm{C}$}

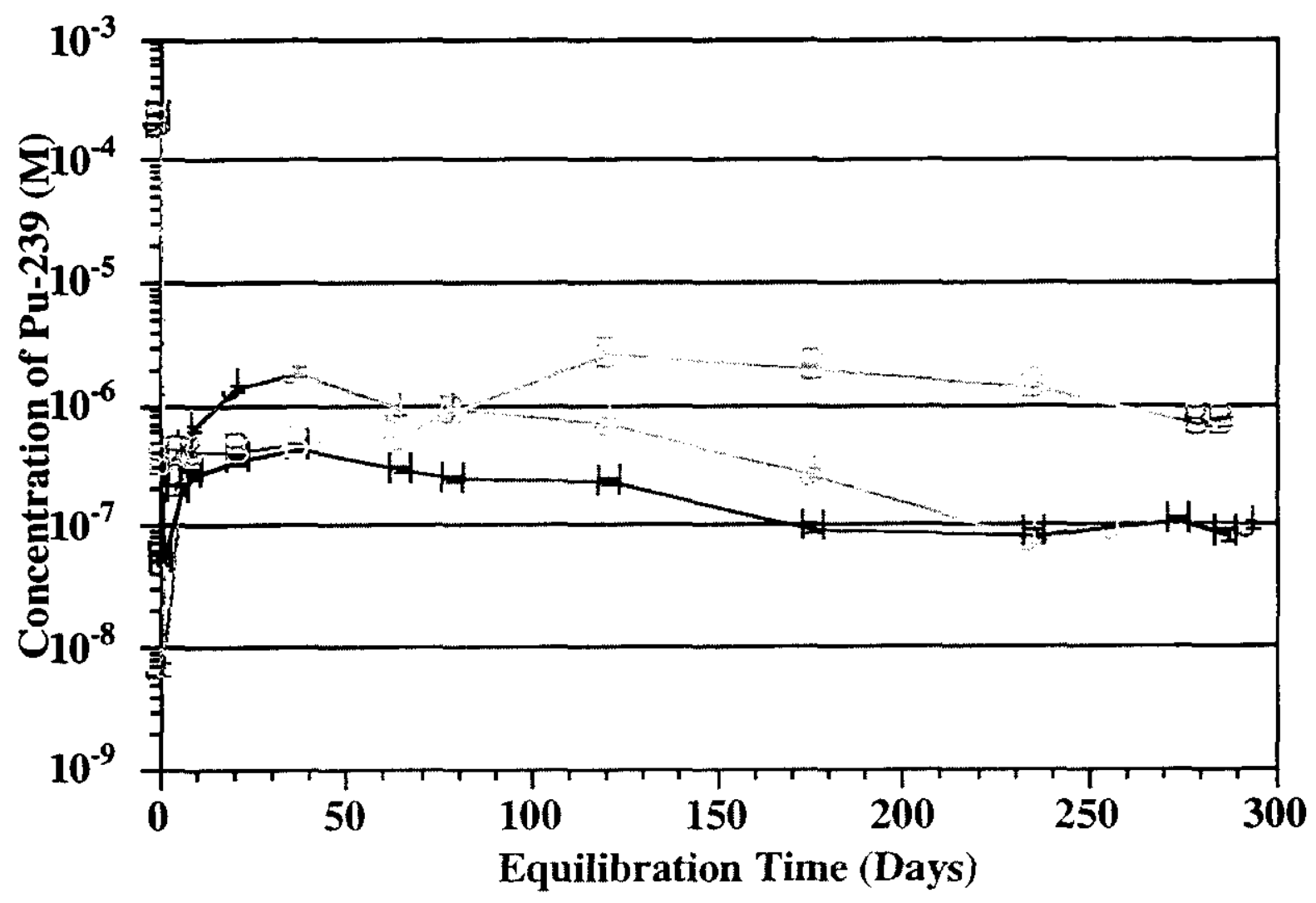

pH 6, Oversaturation

$+\mathrm{pH} 7$. Oversaturation

$\mathrm{pH} 8.5$, Oversaturation

Figure 13. Solution concentrations of ${ }^{239} \mathrm{Pu}$ in contact with precipitate obtained from supersaturation of UE-25p \#1 groundwater at $60^{\circ} \mathrm{C}$ as a function of time. $\mathrm{pH} 6.0 \pm 0.1$ (closed circles), $\mathrm{pH} 7.0 \pm 0.1$ (closed triangles), and $\mathrm{pH} 8.5 \pm 0.1$ (closed squares). The plutonium was added initially (day 0 ) as $\mathrm{Pu}^{4+}$; initial concentrations were $2.2 \times 10^{-4} \mathrm{M}$ (pH 6), $2.2 \times 10^{-4} \mathrm{M}(\mathrm{pH} 7)$, and $2.0 \times 10^{-4} \mathrm{M}$ ( $\mathrm{pH} \mathrm{8.5).} \mathrm{Undersaturation} \mathrm{experiments}$ at $\mathrm{pH} 6.0$ (open circles), $\mathrm{pH} 7.0$ (open triangles), and $\mathrm{pH} 8.5$ (open squares) were started with precipitates obtained in the supersaturation experiments at their respective $\mathrm{pH}$ values. 


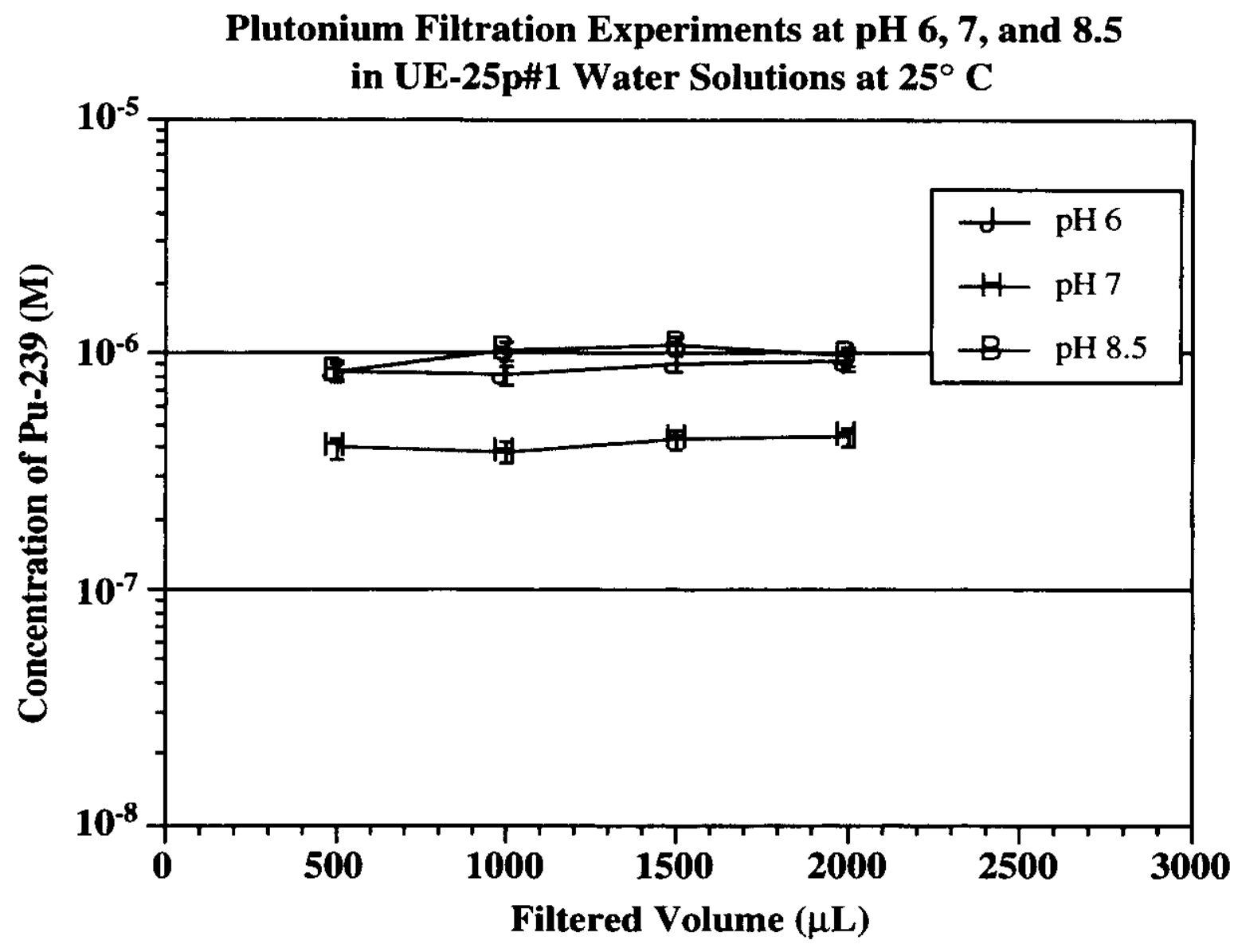

Figure 14. Results of Pu filtration experiments at $25^{\circ} \mathrm{C}$ and $\mathrm{pH} 6,7$, and 8.5 conducted 83 days after the start of the experiments. 


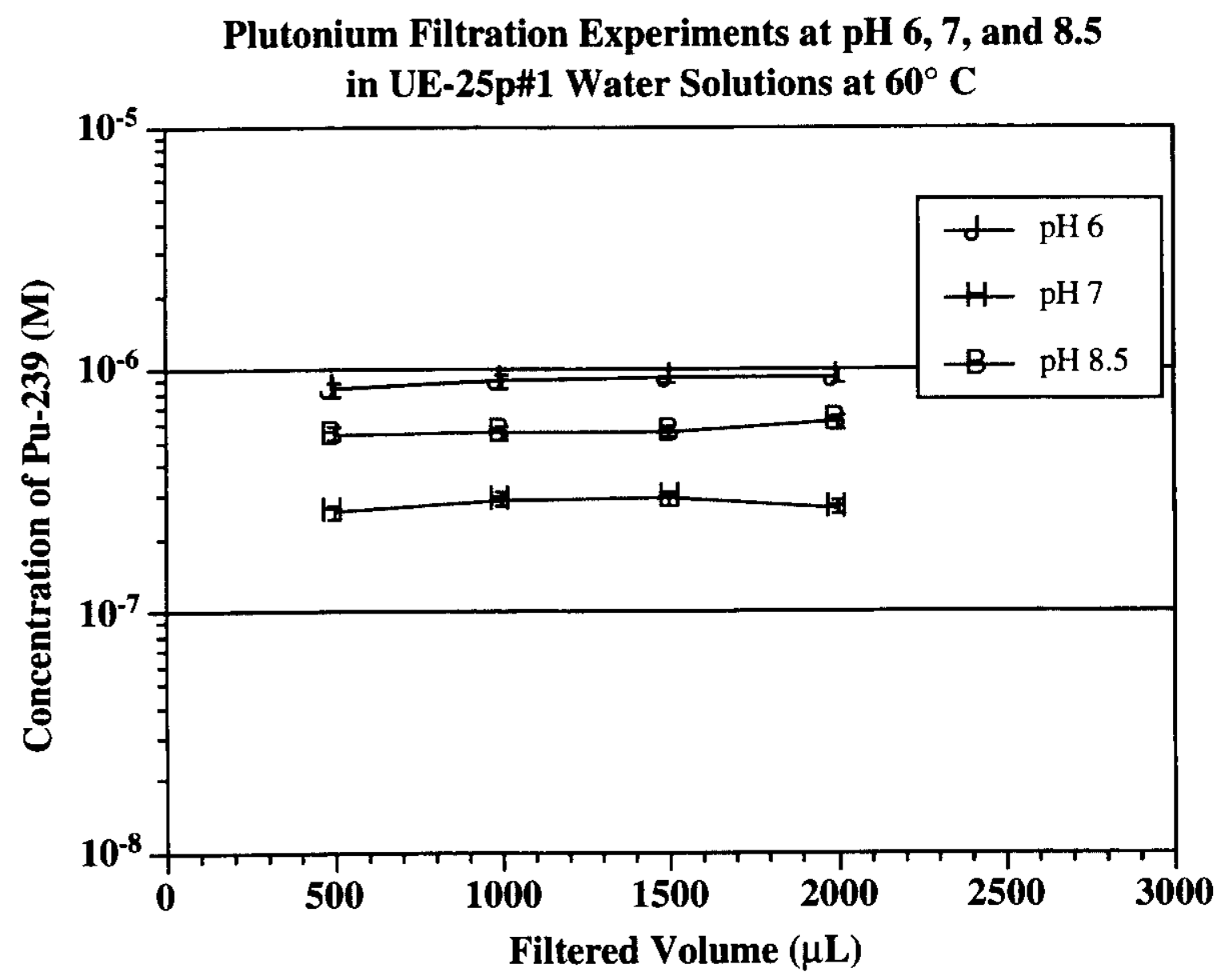

Figure 15. Results of $\mathrm{Pu}$ filtration experiments at $60^{\circ} \mathrm{C}$ and $\mathrm{pH} 6,7$, and 8.5 conducted 65 days after the start of the experiments.

In summary, plutonium concentrations significantly decreased with increasing temperature at $\mathrm{pH} 6$ and 7 . The concentration at $\mathrm{pH} 8.5$ hardly decreased at all with increasing temperature. At both temperatures the concentrations were highest at $\mathrm{pH} 8.5$, lowest at $\mathrm{pH} 7$, and in between at $\mathrm{pH} 6$.

\subsubsection{Speciation}

The plutonium supernatant solutions at steady state were analyzed for their oxidation state distributions. Speciation studies are made difficult by the low solubility of plutonium in UE-25p \#1 groundwater. The solutions' concentration levels lie below the sensitivity range of methods such as absorption spectrophotometry, which would allow the direct measurement of the species present. Therefore, we developed a method to determine the plutonium oxidation states indirectly. The method 
involves a combination of solvent extractions that allows us to determine the relative amounts of plutonium oxidation states in solution. Table XV lists the methods used to determine the distribution of plutonium oxidation states in the $25^{\circ} \mathrm{C}$ experiments, and Table XVI lists the methods used to determine the distribution of plutonium oxidation states in the $60^{\circ} \mathrm{C}$ experiments.

Table XV. Methods Used for Determining Plutonium Oxidation States in Solution at $25^{\circ} \mathrm{C}$.

\begin{tabular}{|c|c|c|c|}
\hline \multirow{2}{*}{\multicolumn{2}{|c|}{ Method }} & \multicolumn{2}{|c|}{ Oxidation State Distribution } \\
\hline & & Organic Phase & Aqueous Phase \\
\hline 1. & $\begin{array}{l}0.5 \text { M TTA Extraction at } \\
\mathrm{pH}=0\end{array}$ & $(+4)$ & $(+3,+5,+6, p)^{a}$ \\
\hline 2. & $\begin{array}{l}0.5 \text { M TTA Extraction at } \\
\mathrm{pH}=0 \text { with } \mathrm{Cr}_{2} \mathrm{O}_{7}^{2-}\end{array}$ & $(+3,+4)$ & $(+5,+6, p)^{a}$ \\
\hline 3. & $\begin{array}{l}0.5 \mathrm{M} \text { HDEHP Extraction at } \\
\mathrm{pH}=0\end{array}$ & $(+4,+6)$ & $(+3,+5, p)^{\mathrm{a}}$ \\
\hline 4. & $\begin{array}{l}\text { 0.5 M HDEHP Extraction at } \\
\mathrm{pH}=0 \text { with } \mathrm{Cr}_{2} \mathrm{O}_{7}{ }^{2-}\end{array}$ & $(+3,+4,+5,+6)$ & $(p)^{\mathbf{a}}$ \\
\hline
\end{tabular}

(a) $(p)=P u(I V)$ polymer

Table XVI. Methods Used for Determining Plutonium Oxidation States in Solution at $60^{\circ} \mathrm{C}$.

\begin{tabular}{|c|c|c|}
\hline \multirow{2}{*}{ Method } & Oxidation State & Distribution \\
\hline & Organic Phase & Aqueous Phase \\
\hline $\begin{array}{l}\text { 1. } 0.025 \mathrm{M} \text { PMBP Extraction } \\
\text { at } \mathrm{pH}=0\end{array}$ & $(+4)$ & $(+3,+5,+6, p)^{\mathrm{a}}$ \\
\hline $\begin{array}{l}\text { 2. } 0.025 \mathrm{M} \text { PMBP Extraction } \\
\text { at } \mathrm{pH}=0 \text { with } \mathrm{Cr}_{2} \mathrm{O}_{7}^{2-}\end{array}$ & $(+3,+4)$ & $(+5,+6, p)^{a}$ \\
\hline $\begin{array}{l}\text { 3. } 0.5 \mathrm{M} \text { HDEHP Extraction at } \\
\mathrm{pH}=0\end{array}$ & $(+4,+6)$ & $(+3,+5, p)^{a}$ \\
\hline $\begin{array}{l}\text { 4. } 0.5 \mathrm{M} \text { HDEHP Extraction at } \\
\mathrm{pH}=0 \text { with } \mathrm{Cr}_{2} \mathrm{O}_{7}^{2-}\end{array}$ & $(+3,+4,+5,+6)$ & $(p)^{a}$ \\
\hline
\end{tabular}

(a) (p ) = Pu(IV) polymer 
At $\mathrm{pH}$ 0, 2-thenoyltrifluoroacetone (TTA) extracts $\mathrm{Pu}(\mathrm{IV})$ from aqueous solutions. We used TTA to extract $\mathrm{Pu}(\mathrm{IV})$ for our oxidation state determinations at $25^{\circ} \mathrm{C}$. At pH 0 , di-(2-ethylhexyl)orthophosphoric acid (HDEHP) extracts Pu(IV) and Pu(VI). Upon introducing dichromate to the aqueous phase before an extraction, $\mathrm{Pu}(\mathrm{III})$ is oxidized to $\mathrm{Pu}(\mathrm{IV})$ and $\mathrm{Pu}(\mathrm{V})$ is oxidized to $\mathrm{Pu}(\mathrm{VI})$. Using TTA and dichromate, we extract $\mathrm{Pu}$ (III) and $\mathrm{Pu}(\mathrm{IV})$ together by oxidation of $\mathrm{Pu}$ (III) to $\mathrm{Pu}(\mathrm{IV})$. HDEHP with dichromate extracts $\mathrm{Pu}(\mathrm{III}), \mathrm{Pu}(\mathrm{IV}), \mathrm{Pu}(\mathrm{V})$, and $\mathrm{Pu}(\mathrm{VI})$ by oxidation of $\mathrm{Pu}$ (III) to $\mathrm{Pu}(\mathrm{IV})$ and of $\mathrm{Pu}(\mathrm{V})$ to $\mathrm{Pu}(\mathrm{VI})$. This method was tested on solutions of known oxidation state mixtures with both highlevel and trace-level concentrations. ${ }^{15}$ The oxidation of $\mathrm{Pu}(\mathrm{III})$ to $\mathrm{Pu}(\mathrm{IV})$ is instantaneous when dichromate is introduced to the aqueous solution. After several hours, disproportionation and/or the oxidation of $\mathrm{Pu}(\mathrm{IV})$ to $\mathrm{Pu}(\mathrm{V})$ by dichromate may occur, however, the kinetics of these undesirable reactions are very slow and do not effect the extractions because they were completed in less than thirty and sixty minutes for the $60^{\circ}$ and $25^{\circ} \mathrm{C}$ experiments, respectively.

For the $60^{\circ}$.C experiments, we replaced TTA with 4-benzoyl-3-methyl-1-phenyl-2-pyrazolin-5one (PMBP). At pH 0, PMBP extracts Pu(IV) as does thenoyltrifluoroacetone (TTA), but PMBP does so more efficiently and is more resistant to decomposition by oxidants, such as dichromate. Because PMBP extracts much more efficiently than TTA, we were able to decrease the concentration of extractant by a factor of twenty to aid in the nuclear counting of the fractions. This method was tested on plutonium solutions containing millimolar carbonate concentrations. The oxidation state distribution was measured at the same time by Laser Induced Photoacoustic Spectroscopy (LIPAS) and by our extraction method. ${ }^{34}$ In testing this method, we also performed extractions with TTA at pH 0 in addition to the PMBP separations to verify that the two extractants produce the same results. In all cases the results were the same.

For the $60^{\circ}$. C experiments, we tried to maintain the temperature as well as it was experimentally possible. Although we mixed the aqueous and organic phase for one minute at ambient temperature using a Vortex mixer, we separated the phases in a centrifuge heated to $60^{\circ} \mathrm{C}$. There is, however, the possibility that the oxidation state distributions at $60^{\circ} \mathrm{C}$ may have been affected by the handling-induced temperature change. Therefore, the derived results may be more semiquantitative.

In order to minimize the changing of plutonium oxidation states in solution, each of the extractions was carried out independently on a new solution sample. By taking differences in the relative amounts obtained in the four separations, the percent of each oxidation state can then be determined. Results of these studies are given in Table XVII, and displayed in Figures 16, 17, and 18, for pH 6.0, 7.0, and 8.5 , respectively.

At $25^{\circ} \mathrm{C}$, all solutions contained predominantly $\mathrm{Pu}(\mathrm{V})$ and $\mathrm{Pu}(\mathrm{IV})$. With increasing $\mathrm{pH}$, the relative amount of $\mathrm{Pu}(\mathrm{V})$ decreased, and the relative amount of $\mathrm{Pu}(\mathrm{IV})$ increased. A small amount of $\mathrm{Pu}$ (VI) was also present in the $\mathrm{pH} 7$ solubility experiment. $\mathrm{Pu}(\mathrm{III})$ and $\mathrm{Pu}(\mathrm{IV})$ polymer were present in insignificant amounts in all experiments at $25^{\circ} \mathrm{C}$. 
At $60^{\circ} \mathrm{C}$, all solutions contained Pu(VI) almost completely. As with the $\mathrm{pH} 8.5$ experiment at $25^{\circ}$, the relative amount of $\mathrm{Pu}(\mathrm{IV})$ increased slightly. $\mathrm{Pu}(\mathrm{III})$ and $\mathrm{Pu}(\mathrm{IV})$ polymer and $\mathrm{Pu}(\mathrm{V})$ were present in insignificant amounts in all experiments at $60^{\circ} \mathrm{C}$.

These observed valence distributions cannot be explained by disproportionation equilibria and complex stabilization. ${ }^{35}$ It is possible that oxidation products formed by $\alpha$-radiolysis of the water may cause the predominance of high oxidation states. It is noteworthy that the solutions were filtered through a $4.1 \mathrm{~nm}$ filter prior to the oxidation state determination because we wanted to determine only the true soluble plutonium fraction without any colloidal or polymeric plutonium being present. Therefore, we refer to the $\mathrm{Pu}$ (IV) polymer in the context of this determination as to the fraction that is smaller than 4.1 $\mathrm{nm}$. This colloidal or polymeric plutonium does not participate in the ionic solution equilibrium, and its removal will not immediately affect the oxidation state distribution in the solution.

Another possible explanation for the predominance of high oxidation states at steady state may lie in the plutonium stock solution itself. Because of the limits of detection associated with our spectrophotometer, the solubility experiments may have contained initial concentrations of $\mathrm{Pu}$ (III), $\mathrm{Pu}(\mathrm{V})$, and $\mathrm{Pu}(\mathrm{VI})$ as high as $2 \times 10^{-6}, 6 \times 10^{-6}$, and $2 \times 10^{-7} \mathrm{M}$, respectively. These concentrations could result based on the maximum concentrations that would have been undetected in the $10^{-2} \mathrm{MPu}(\mathrm{IV})$ stock solution. Assuming complete precipitation of the lower oxidation states, one could conclude that the potential initial concentrations of $\mathrm{Pu}(\mathrm{V})$ and $\mathrm{Pu}(\mathrm{VI})$ may represent the steady-state oxidation state distributions and the total aqueous plutonium concentrations. However, after completing oxidation state determinations in the corresponding plutonium undersaturation experiments in UE-25p \# 1 groundwater at $60^{\circ} \mathrm{C}$ (results will be reported in a later publication) the above speculation cannot be confirmed that trace level oxidation state impurities in the stock solution used to start the oversaturation experiments may be causing the plutonium solubility limits and the oxidation state distribution in solution. The undersaturation experiments were started with only the solid phases obtained in the oversaturation experiments. The results from oxidation state determinations on the undersaturation experiments showed combined relative amounts for $\mathrm{Pu}(\mathrm{V})$ and $\mathrm{Pu}(\mathrm{VI})$ of 96,98 , and 90 percent for solutions at $\mathrm{pH}$ 6,7 , and 8.5 , respectively. The undersaturation experiment at $\mathrm{pH} 8.5$ also showed a small amount of $\mathrm{Pu}(\mathrm{IV})$, approximately 10 percent. This finding is in excellent agreement with the result from the corresponding oversaturation experiment at $\mathrm{pH}$ 8.5. We also note that the slightly lower, yet still oxic, Eh value measured for the $\mathrm{pH} 8.5$ experiment also supports the increased presence of $\mathrm{Pu}(\mathrm{IV})$. Here again, all three measurements were reproduced in the corresponding undersaturation experiments to within 21 $\mathrm{mV}$.

In light of this, the predominance of high oxidation states appears to be a real effect, yet more investigation into the species responsible for the oxidation of the plutonium in solution is desirable. 
Table XVII. Plutonium oxidation state determinations in UE-25p \# 1 at $\mathrm{pH}$ values 6,7 , and 8.5 and $25^{\circ}$ and $60^{\circ} \mathrm{C}$.

\begin{tabular}{|c|c|c|c|c|c|c|c|c|}
\hline \multirow{3}{*}{$\mathrm{pH}$} & \multicolumn{6}{|c|}{ Oxidation States (\%) } \\
\cline { 2 - 10 } & $\begin{array}{r}\mathrm{Pu}(\mathrm{IV}) \text {-polymer }+ \\
\mathrm{Pu}(\mathrm{III})\end{array}$ & \multicolumn{2}{|c|}{$\mathrm{Pu}(\mathrm{IV})$} & \multicolumn{2}{c|}{$\mathrm{Pu}(\mathrm{V})$} & \multicolumn{2}{c|}{$\mathrm{Pu}(\mathrm{VI})$} \\
\cline { 2 - 10 } & $25^{\circ} \mathrm{C}$ & $60^{\circ} \mathrm{C}$ & $25^{\circ} \mathrm{C}$ & $60^{\circ} \mathrm{C}$ & $25^{\circ} \mathrm{C}$ & $60^{\circ} \mathrm{C}$ & $25^{\circ} \mathrm{C}$ & $60^{\circ} \mathrm{C}$ \\
\hline \hline 5.9 & $(3 \pm 1)$ & $(1 \pm 1)$ & $(9 \pm 1)$ & $(1 \pm 1)$ & $(85 \pm 7)$ & $(4 \pm 1)$ & $(3 \pm 3)$ & $(94 \pm 11)$ \\
\hline 7.0 & $(2 \pm 1)$ & $(2 \pm 1)$ & $(12 \pm 1)$ & $(1 \pm 1)$ & $(78 \pm 7)$ & $(5 \pm 1)$ & $(9 \pm 4)$ & $(93 \pm 11)$ \\
\hline 8.5 & $(3 \pm 1)$ & $(5 \pm 2)$ & $(31 \pm 1)$ & $(10 \pm 1)$ & $(64 \pm 6)$ & $(0)$ & $(2 \pm 1)$ & $(86 \pm 12)$ \\
\hline
\end{tabular}

Regarding the steady-state plutonium concentrations from oversaturation and undersaturation experiments: steady-state plutonium concentrations in the solubility experiments at $\mathrm{pH} 6$ and 7 from undersaturation agreed with their respective oversaturation experiments to within 20 percent; the undersaturation experiment at $\mathrm{pH} 8.5$ provided a steady-state plutonium concentration that was ten times lower than that obtained from oversaturation. Further discussion will follow in a paper that compares undersaturation results with oversaturation results. 


\section{Plutonium Oxidation State Distributions in UE-25p\#1 \\ Water at $25^{\circ}$ and $60^{\circ} \mathrm{C}$ and $\mathrm{pH} 6$}

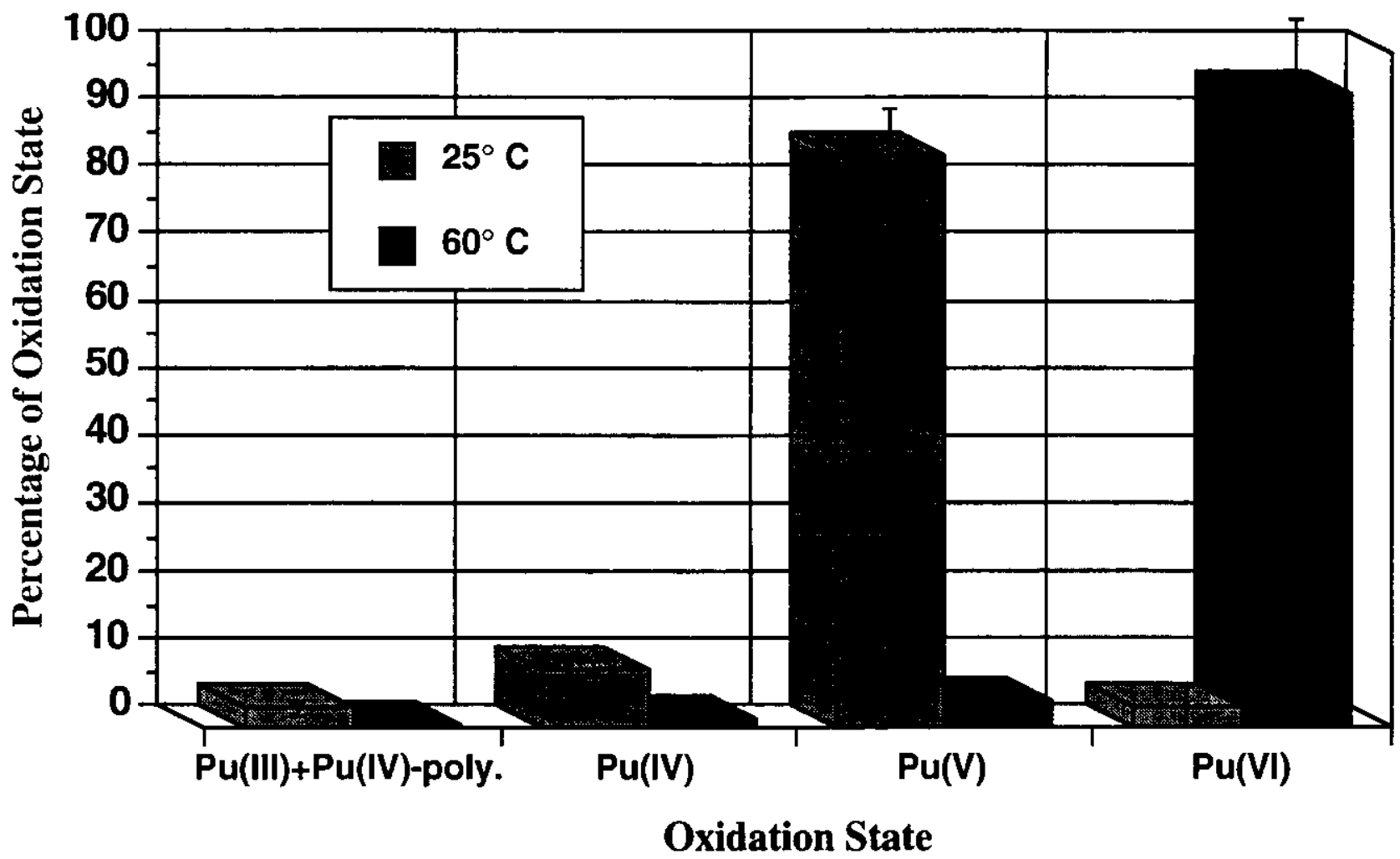

Figure 16. Plutonium oxidation state distributions of the supernatant at steady state for $\mathrm{Pu}^{4+}$ solubility experiments in UE-25p \#1 groundwater at $\mathrm{pH} 6.0$ and $25^{\circ}$ and $60^{\circ} \mathrm{C}$. The solutions were filtered through $4.1 \mathrm{~nm}$ filters. 


\section{Plutonium Oxidation State Distributions in UE-25p\#1 Water at $25^{\circ}$ and $60^{\circ} \mathrm{C}$ and $\mathrm{pH} 7$}

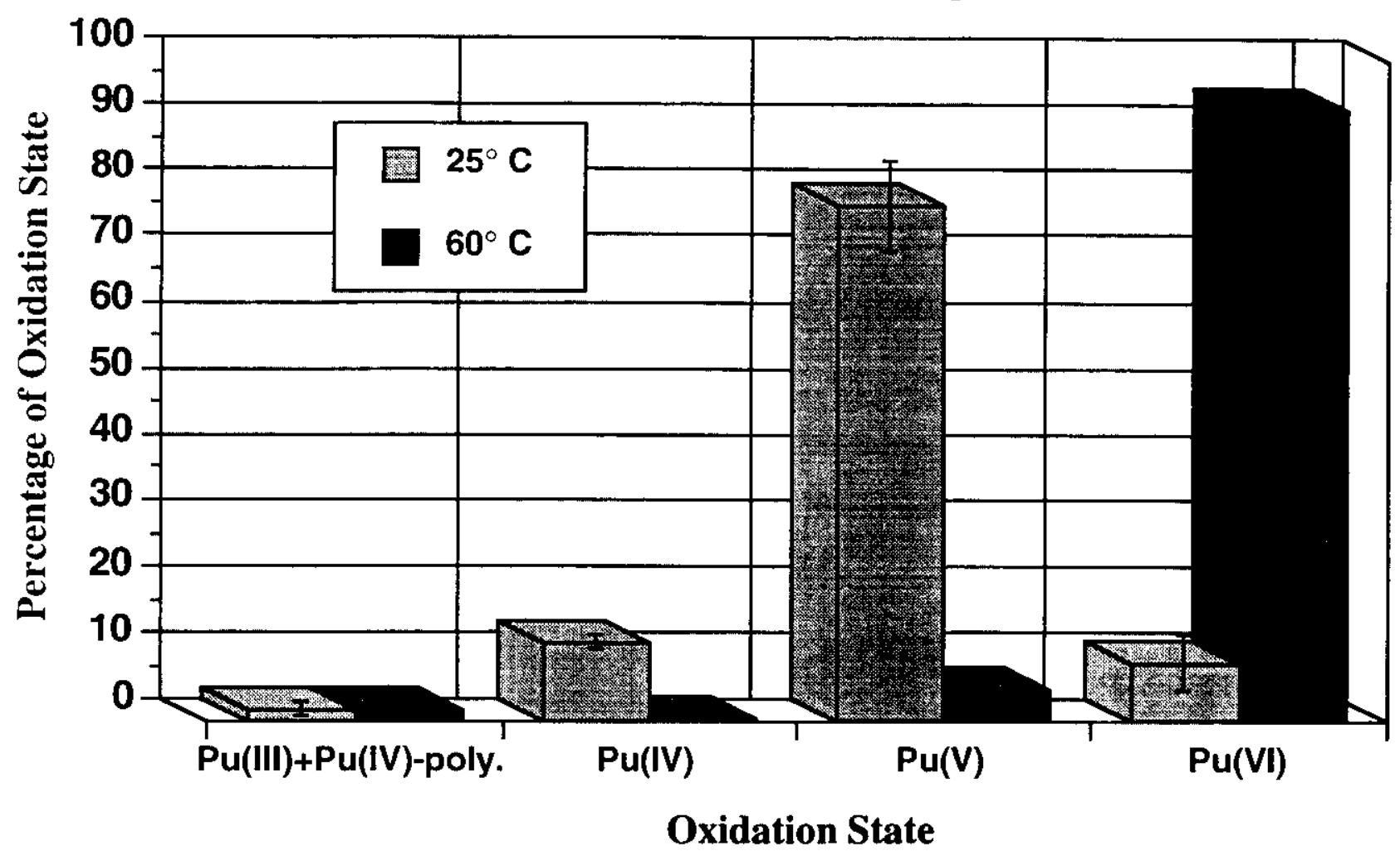

Figure 17. Plutonium oxidation state distributions of the supernatant at steady state for $\mathrm{Pu}^{4+}$ solubility experiments in UE-25p \#1 groundwater at $\mathrm{pH} 7.0$ and $25^{\circ}$ and $60^{\circ} \mathrm{C}$. The solutions were filtered through $4.1 \mathrm{~nm}$ filters. 


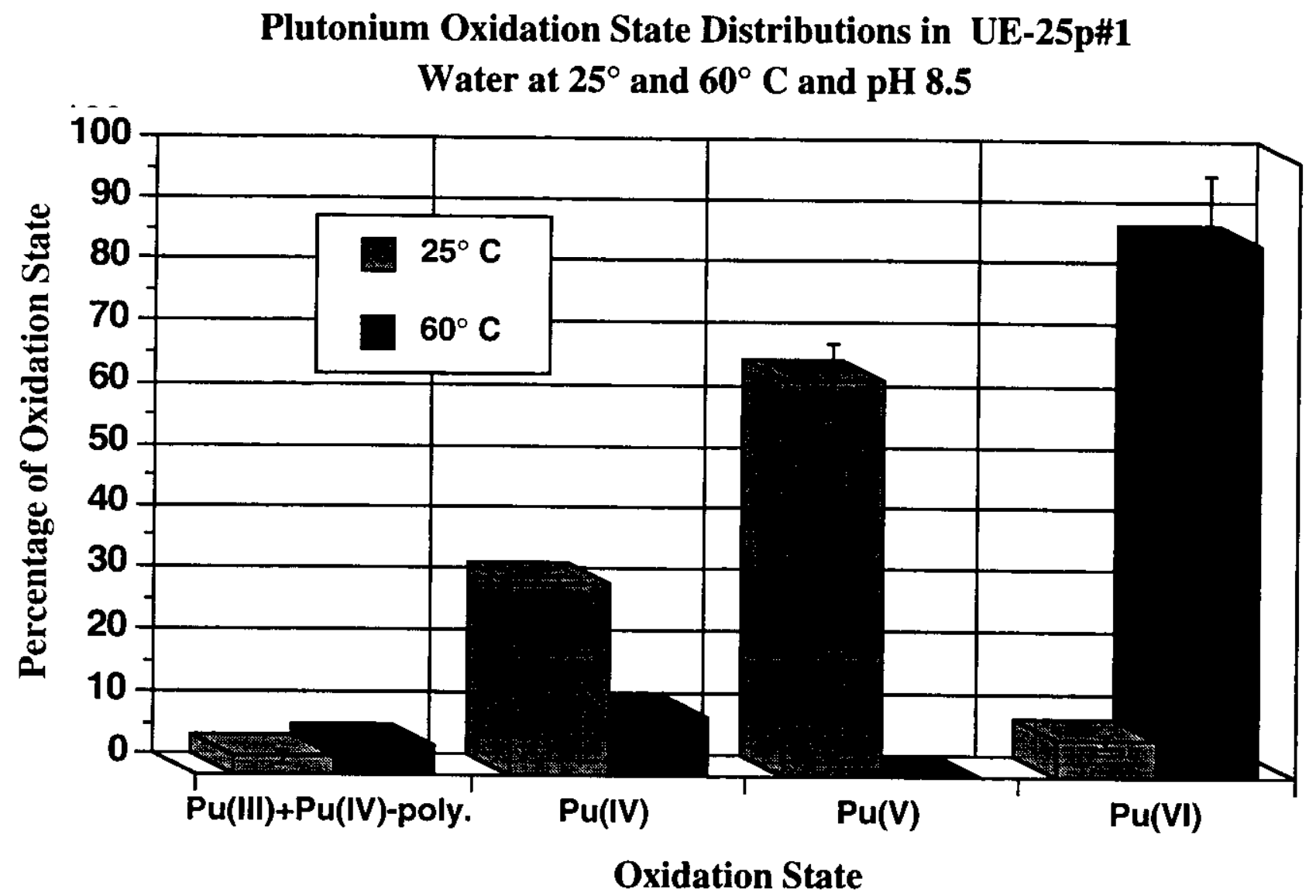

Figure 18. Plutonium oxidation state distributions of the supernatant at steady state for $\mathrm{Pu}^{4+}$ solubility experiments in UE-25p \#1 groundwater at $\mathrm{pH} 8.5$ and $25^{\circ}$ and $60^{\circ} \mathrm{C}$. The solutions were filtered through $4.1 \mathrm{~nm}$ filters.

\subsubsection{Identification of Solids}

The plutonium precipitates found in the solutions at $25^{\circ}$ and $60^{\circ} \mathrm{C}$ were collected by centrifugation, washed with a small amount of $\mathrm{CO}_{2}$-free water, and dried with an argon jet. All precipitates, with the exception of the solid obtained in the $\mathrm{pH} 8.5$ experiment at $60^{\circ} \mathrm{C}$, had a dark green appearance similar to that of $\mathrm{Pu}(\mathrm{IV})$ polymer. D-spacings and relative intensities of the $\mathrm{x}$-ray powder diffraction patterns from the precipitates are listed in Table XVIII. The plutonium solids at $\mathrm{pH} 5.9$ and $\mathrm{pH} 7.0$ showed two identical diffraction lines only. Each of these lines was diffuse indicating a low degree of crystallinity. We found no reference pattern to assign the lines. They were compared to patterns of crystalline $\mathrm{PuO}_{2}{ }^{36}$, $\mathrm{PuO}_{3} \cdot 0.8 \mathrm{H}_{2} \mathrm{O}^{37}, \mathrm{KPuO}_{2} \mathrm{CO}_{3}{ }^{38}, \mathrm{NH}_{4} \mathrm{PuO}_{2} \mathrm{CO}_{3}{ }^{38}$, and $\mathrm{PuO}_{2} \mathrm{CO}_{3}{ }^{39}$. The $\mathrm{pH} 8.5$ precipitate is compared with $\mathrm{PuO}_{2}$ in Table XIX. A good match was obtained between these two solids. Four of 9 lines in the pH 8.5 precipitate fit $\mathrm{PuO}_{2}$ to within $0.01 \AA$; six of 9 lines fit to within $0.06 \AA$. 
We tested all plutonium precipitates at $25^{\circ} \mathrm{C}$ for carbonates. When treated with $1 \mathrm{M} \mathrm{HCl}$, no $\mathrm{CO}_{2}$ evolved and no dissolution of the precipitate was observed. This was confirmed by gamma spectroscopy of these filtered $(0.22 \mu \mathrm{m})$ solutions which showed only ${ }^{241} \mathrm{Am}$ present and no ${ }^{239} \mathrm{Pu}$. The ${ }^{241} \mathrm{Am}$ is the daughter of ${ }^{241} \mathrm{Pu}$ which is present in small amounts in the ${ }^{239} \mathrm{Pu}$ stock solution. The precipitates were then boiled with $6 \mathrm{M} \mathrm{HCl}$ and even then did not dissolve completely. Dissolution was only achieved after addition of $\mathrm{NaF}$ and continuous boiling. This is a clear indication that the solids were either polymeric $\mathrm{Pu}$ (IV) or $\mathrm{PuO}_{2}$ (in the case of the $\mathrm{pH} 8.5$ precipitate).

Table XX lists the $\mathrm{X}$-ray powder patterns for the solids that we obtained from the $\mathrm{pH} 7$ and 8.5 experiments at $60^{\circ} \mathrm{C}$. The powder pattern from the $\mathrm{pH} 6$ experiment showed only a diffuse band indicating a low degree of crystallinity which is typical for $\mathrm{Pu}(\mathrm{IV})$-polymer. The powder pattern from the solid obtained in the $\mathrm{pH} 7$ experiment showed the same diffuse band plus one weak line at $3.03 \AA$. Again, this shows a very low degree of crystallinity and is consistent with results for polymeric $\mathrm{Pu}(\mathrm{IV})$. The solid from the $\mathrm{pH} 8.5$ experiment at $60^{\circ} \mathrm{C}$ produced a powder pattern that contained 7 diffraction lines. All of the diffraction lines were weak and trace lines with the exception of one, at a d-spacing of $3.26 \AA$. This powder pattern was compared to patterns of crystalline $\mathrm{PuO}_{2}{ }^{36}, \mathrm{PuO}_{3} \cdot 0.8 \mathrm{H}_{2} \mathrm{O}^{37}$, $\mathrm{KPuO}_{2} \mathrm{CO}_{3}{ }^{38}, \mathrm{NH}_{4} \mathrm{PuO}_{2} \mathrm{CO}_{3}{ }^{38}$, and $\mathrm{PuO}_{2} \mathrm{CO}_{3}{ }^{39}$. No match was found among these patterns, so all we can conclude is that the solid obtained at $\mathrm{pH} 8.5$ and $60^{\circ} \mathrm{C}$ is crystalline but cannot be identified.

In summary, the solids formed at $\mathrm{pH} 6$ and 7 at both $25^{\circ}$ and $60^{\circ} \mathrm{C}$ appear to be amorphous $\mathrm{Pu}(\mathrm{IV})$ polymer ; whereas, the solid produced at $\mathrm{pH} 8.5$ and $25^{\circ} \mathrm{C}$ matches the pattern of $\mathrm{PuO}_{2}$ and solid produced at $\mathrm{pH} 8.5$ and $60^{\circ} \mathrm{C}$ is crystalline but unidentified.

Table XVIII. X-ray powder diffraction patterns of plutonium solid phases in UE-25p \#1 groundwater

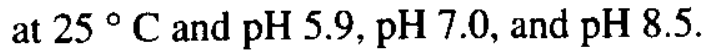

\begin{tabular}{|c|c|c|c|c|c|}
\hline \multicolumn{2}{|c|}{ pH 5.9 } & \multicolumn{2}{|c|}{$\mathrm{pH} 7.0$} & \multicolumn{2}{|c|}{ pH 8.5} \\
\hline $\mathrm{d}(\AA)$ & $\underline{I}^{\mathrm{a}}$ & $\underline{\mathrm{d}(\AA)}$ & $\mathrm{I}^{\mathrm{a}}$ & $\underline{\mathrm{d}(\AA)}$ & $\underline{I}^{\mathrm{a}}$ \\
\hline 1.99 & $\mathrm{~s}$ & 1.98 & $\mathrm{~s}$ & $\begin{array}{l}3.14 \\
2.71 \\
1.99 \\
1.91\end{array}$ & $\begin{array}{l}\mathrm{s} \\
\mathrm{m} \\
\mathrm{m}- \\
\mathrm{m}+\end{array}$ \\
\hline 1.73 & w & 1.73 & $w$ & $\begin{array}{l}1.63 \\
1.56 \\
1.35 \\
1.24 \\
1.21\end{array}$ & $\begin{array}{l}\mathrm{m}+ \\
\mathrm{w}+ \\
\mathrm{w} \\
\mathrm{w}+ \\
\mathrm{w}\end{array}$ \\
\hline
\end{tabular}

(a) Relative intensities visually estimated: $v s=$ very strong, $s=$ strong, $m=$ medium, $w=$ weak, $\mathrm{t}=$ trace . 
Table XIX. X-ray powder diffraction patterns of plutonium solid phases in UE-25p \#1 groundwater at $25^{\circ} \mathrm{C}$ and $\mathrm{pH} 8.5$ compared with the pattern of $\mathrm{PuO}_{2}{ }^{36}$

\begin{tabular}{|ll|ll|}
\hline \multicolumn{2}{|c|}{$\mathrm{pH} 8.5$} & \multicolumn{2}{|c|}{$\mathrm{PuO}_{2}$} \\
\hline $\mathrm{d}(\AA)$ & $\left.\mathrm{I}^{\mathrm{a}}\right)$ & $\mathrm{d}(\AA)$ & $\mathrm{I}^{\mathrm{a}}$ \\
3.14 & $\mathrm{~s}$ & 3.08 & $\mathrm{~s}$ \\
2.71 & $\mathrm{~m}$ & 2.67 & $\mathrm{w}$ \\
1.99 & $\mathrm{~m}-$ & & \\
1.91 & $\mathrm{~m}+$ & 1.89 & $\mathrm{~s}-$ \\
1.63 & $\mathrm{~m}+$ & 1.62 & $\mathrm{~s}-$ \\
1.56 & $\mathrm{w}+$ & 1.55 & $\mathrm{w}$ \\
1.35 & $\mathrm{w}$ & 1.23 & $\mathrm{~m}$ \\
1.24 & $\mathrm{w}+$ & 1.20 & $\mathrm{~m}$ \\
1.21 & $\mathrm{w}$ & 1.20 & $\mathrm{~m}$ \\
& & 1.10 & $\mathrm{~m}$ \\
& & 1.04 & $\mathrm{w}$ \\
& & 0.96 & $\mathrm{~s}-$ \\
& & 0.91 & $\mathrm{~m}$ \\
& & 0.85 & $\mathrm{~m}$ \\
& & 0.82 & $\mathrm{~m}$ \\
& & 0.81 & $\mathrm{~m}$ \\
& & 0.78 & $\mathrm{w}$ \\
& & & \\
\hline
\end{tabular}

(a) Relative intensities visually estimated: vs = very strong, $\mathrm{s}=$ strong, $\mathrm{m}=$ medium, $\mathrm{w}=$ weak, $\mathrm{t}=$ trace

Table XX. X-ray powder diffraction patterns of plutonium solid phases in UE-25p \#1 groundwater at $60^{\circ} \mathrm{C}$ and $\mathrm{pH} 7.0$ and $\mathrm{pH} 8.5$.

\begin{tabular}{|cc|cc|}
\hline \multicolumn{2}{|c|}{$\mathrm{pH} 7.0$} & \multicolumn{2}{c|}{$\mathrm{pH} 8.5$} \\
\hline \multirow{2}{*}{$\mathrm{d}(\AA)$} & $\mathrm{I}^{\mathrm{a}}$ & $\mathrm{d}(\AA)$ & $\mathrm{I}^{\mathrm{a}}$ \\
& & 3.40 & $\mathrm{w}+$ \\
3.03 & $\mathrm{w}$ & 3.26 & $\mathrm{~s}-$ \\
& & 3.04 & $\mathrm{t}$ \\
& & 2.71 & $\mathrm{t}$ \\
& & 2.52 & $\mathrm{t}$ \\
& & 2.03 & $\mathrm{w}$ \\
& & 1.98 & $\mathrm{w}$ \\
& & & \\
& & & \\
\hline
\end{tabular}

(a) Relative intensities visually estimated: vs = very strong, $\mathrm{s}=$ strong, $\mathrm{m}=$ medium, $\mathrm{w}=$ weak, $\mathrm{t}=$ trace . 


\subsection{Americium}

We used non-radioactive neodymium in place of americium to minimize radiation-induced degradation of the solubility cell. Neodymium is chemically similar to americium. ${ }^{40}$ It has an ionic radius of $0.983 \AA$ that is very close to that of $0.975 \AA$ for trivalent americium. ${ }^{41}$ The neodymium was spiked with a small amount of ${ }^{241} \mathrm{Am}$ to facilitate sample counting using the $59.54-\mathrm{keV}$ photo-peak. The use of the neodymium spiked with ${ }^{241}$ Am tracer reduced the alpha-radiation to a fraction of the radiation that would have been present if we had used pure ${ }^{243} \mathrm{Am}$ instead. The mole ratios $(([\mathrm{Am}]+[\mathrm{Nd}]) /[\mathrm{Am}])$ used in the $25^{\circ}$ and $60^{\circ} \mathrm{C}$ solubility experiments were $87.32: 1$ and $113.7: 1$, respectively.

We confirmed in an earlier study that neodymium is a good stand-in element for americium. 1 The differences between the solubilities of $\mathrm{Nd} /{ }^{241} \mathrm{Am}$ and pure ${ }^{243} \mathrm{Am}$ were insignificant at each of the studied $\mathrm{pH}$ values. This validates our solubility tests in UE-25p $\# 1$ groundwater at $25^{\circ}$ and $60^{\circ} \mathrm{C}$ where we used neodymium mixed with trace amounts of ${ }^{241} \mathrm{Am}$ as a substitute for ${ }^{243} \mathrm{Am}$.

\subsubsection{Solubility}

Results of the solubility studies are shown in Figure 19. The steady-state concentrations and the solutions' Eh values are given in Table XXI. Concentration profiles as a function of equilibration time and $\mathrm{pH}$ for $25^{\circ}$ and $60^{\circ} \mathrm{C}$ are shown in Figures 20 and 21 , respectively. Individual measurements are listed in Appendix C. Results for the americium/neodymium solubility experiment at $60^{\circ} \mathrm{C}$ and $\mathrm{pH} 7$ are incomplete and of limited value because the experiment was stopped early due to equipment failure. The test cell, equipped with a faulty O-ring, allowed the experimental solution to evaporate. Steady state may not have been reached, and the solution concentration reported in Table XXI was determined from only the last two samplings. 


\section{Americium(III)/Neodymium Solubility Experiments in UE-25p\#1 Water at $25^{\circ}$ and $60^{\circ} \mathrm{C}$}

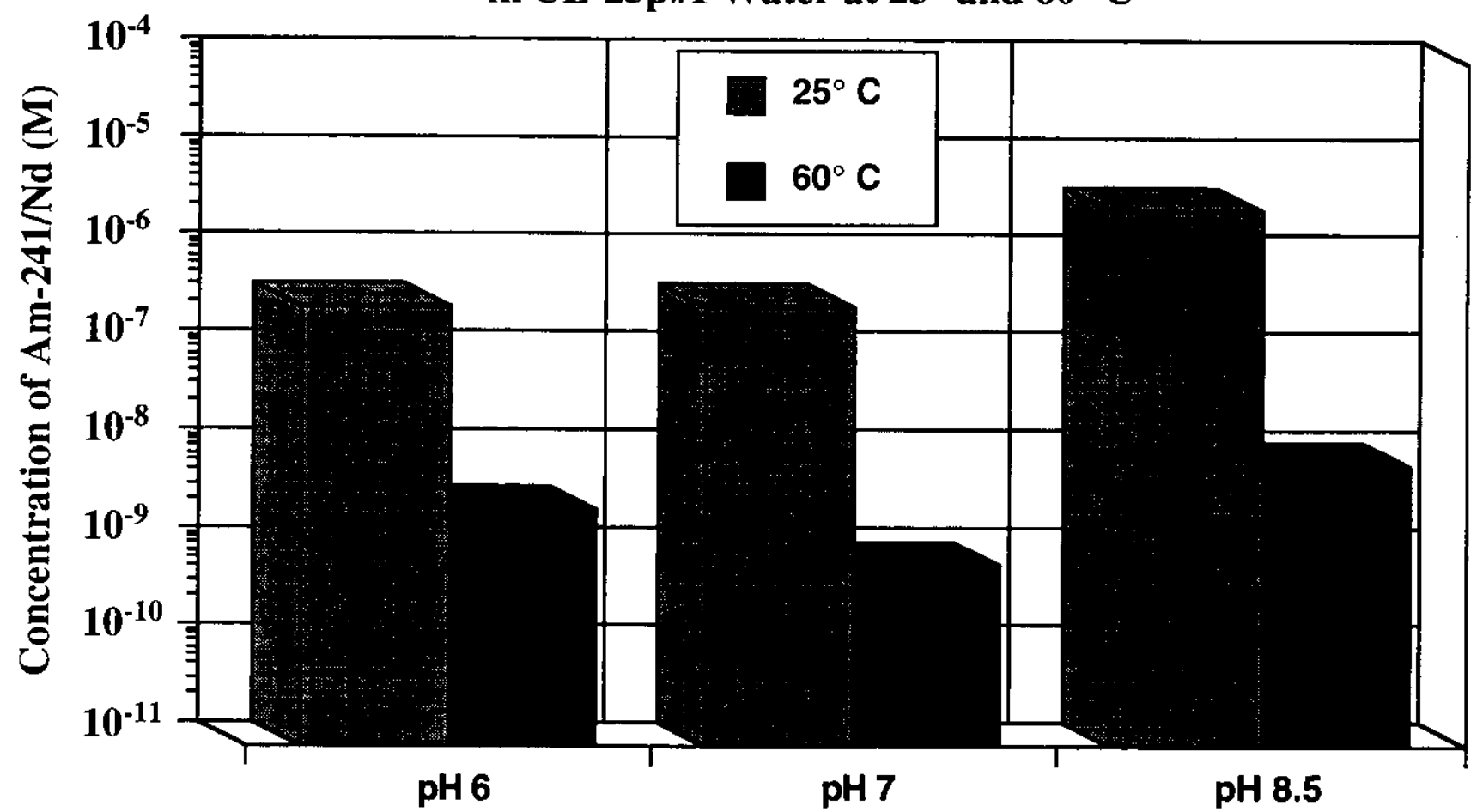

Figure 19. Results for ${ }^{241} \mathrm{Am}^{3+} / \mathrm{Nd}^{3+}$ solubility experiments in UE-25p\#1 groundwater as a function of $\mathrm{pH}$ and temperature.

Table XXI. Comparison of steady-state solution concentrations and Eh for americium/ neodymium in UE-25p \#1 water at $25^{\circ}$ and $60^{\circ} \mathrm{C}$.

\begin{tabular}{|c|c|c|c|c|}
\hline \multirow{3}{*}{ pH } & \multicolumn{4}{|c|}{ Americium(III)/Neodymium } \\
\hline & \multicolumn{2}{|c|}{ Concentration (M) } & \multicolumn{2}{|c|}{ Eh (mV vs. NHE) } \\
\hline & $25^{\circ} \mathrm{C}$ & $60^{\circ} \mathrm{C}$ & $25^{\circ} \mathrm{C}$ & $60^{\circ} \mathrm{C}$ \\
\hline 6 & $(3.1 \pm 1.1) \times 10^{-7}$ & $(2.7 \pm 0.4) \times 10^{-9}$ & $(376 \pm 15)$ & $(370 \pm 15)$ \\
\hline 7 & $(3.2 \pm 1.6) \times 10^{-7}$ & $(7.1 \pm 0.5) \times 10^{-10}$ & $(358 \pm 15)$ & (NA) \\
\hline 8.5 & $(3.1 \pm 0.8) \times 10^{-6}$ & $(7.8 \pm 4.3) \times 10^{-9}$ & $(111 \pm 15)$ & $(220 \pm 15)$ \\
\hline
\end{tabular}




\section{Approach to Equilibrium of UE-25p\#1 Water}

\section{Solutions of Americium(III)/Neodymium at $25^{\circ} \mathrm{C}$}

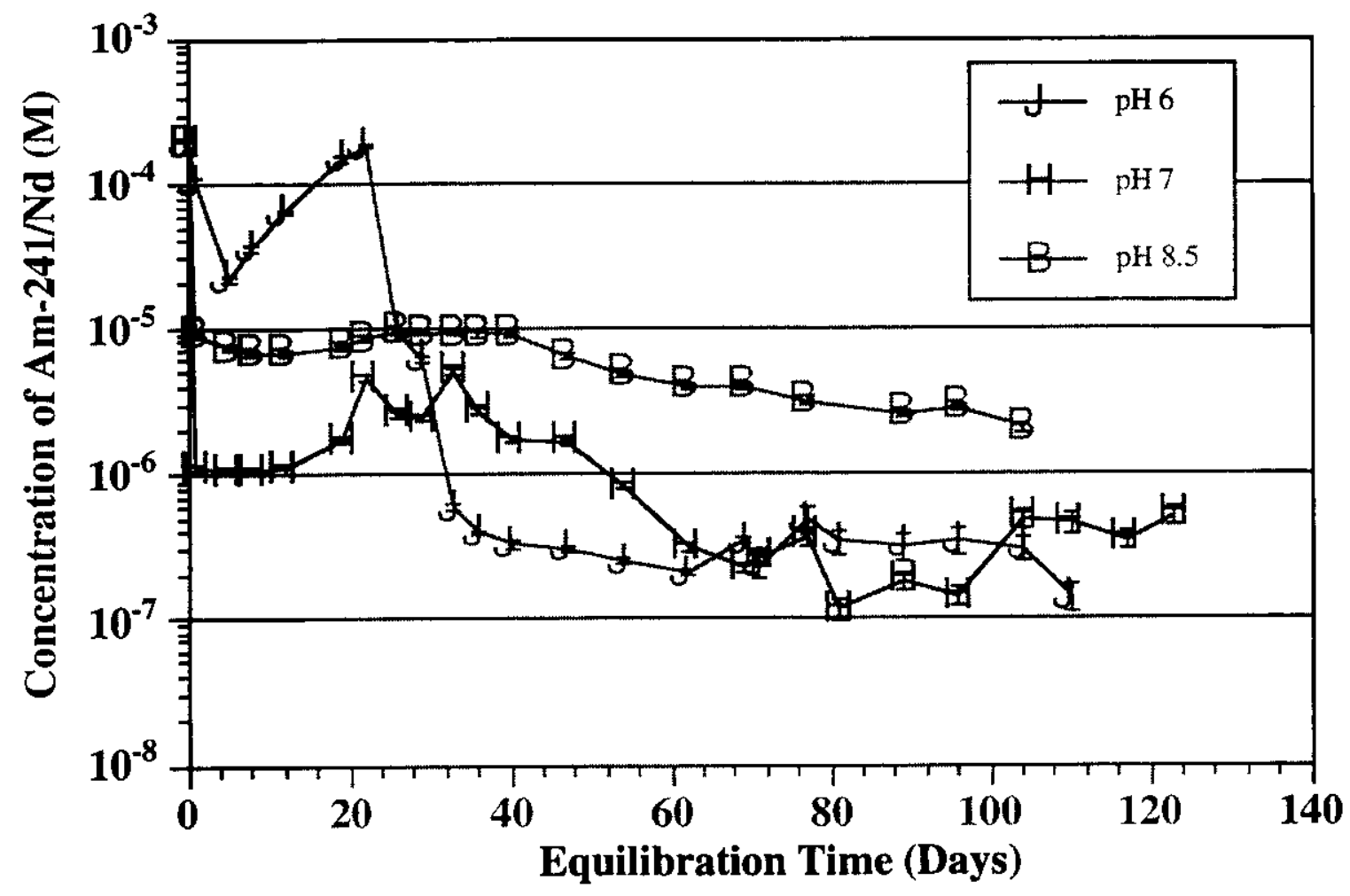

Figure 20. Solution concentrations of ${ }^{241} \mathrm{Am} / \mathrm{Nd}$ in contact with precipitate obtained from supersaturation of UE-25p \#1 groundwater at $25^{\circ} \mathrm{C}$ as a function of time. $\mathrm{pH} 6.0 \pm 0.1$ (closed circles), $\mathrm{pH} 7.0 \pm 0.1$ (closed triangles), and $\mathrm{pH} 8.5 \pm 0.1$ (closed squares). The americium/neodymium was added initially (day 0$)$ as ${ }^{241} \mathrm{Am}^{3+} / \mathrm{Nd}^{3+}$. Initial $\left({ }^{241} \mathrm{Am}^{3+}+\right.$ $\left.\mathrm{Nd}^{3+}\right)$ concentrations were $1.9 \times 10^{-4} \mathrm{M}(\mathrm{pH} 6), 1.9 \times 10^{-4} \mathrm{M}(\mathrm{pH} 7)$, and $1.9 \times 10^{-4} \mathrm{M}(\mathrm{pH}$ 8.5). 


\section{Approach to Equilibrium of UE-25p\#1 Water Solutions of Americium/Neodymium at $60^{\circ} \mathrm{C}$}
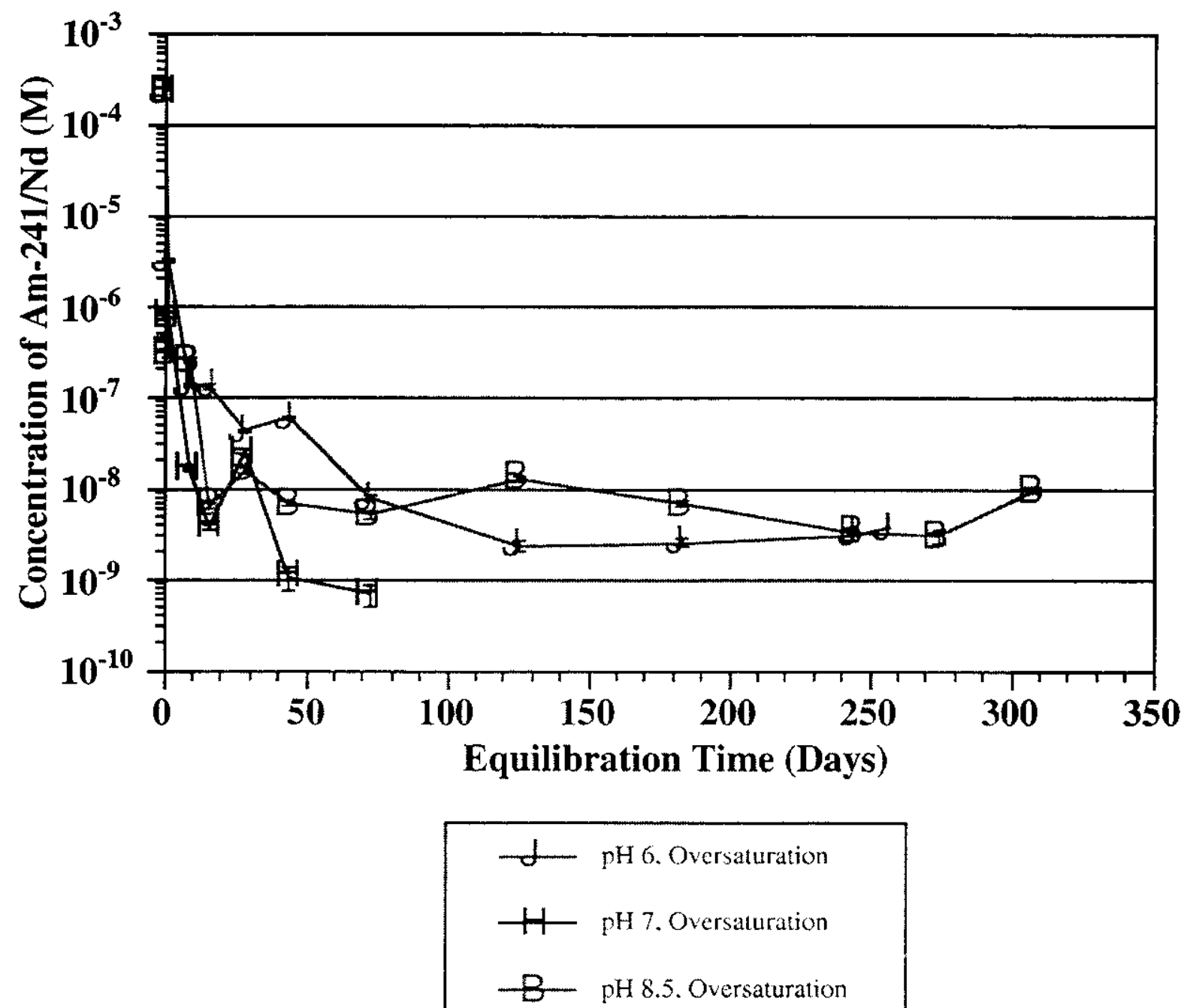

Figure 21. Solution concentrations of ${ }^{241} \mathrm{Am} / \mathrm{Nd}$ in contact with precipitate obtained from supersaturation of UE-25p \# 1 groundwater at $60^{\circ} \mathrm{C}$ as a function of time. $\mathrm{pH} 6.0 \pm 0.1$ (closed circles), $\mathrm{pH} 7.0 \pm 0.1$ (closed triangles), and $\mathrm{pH} 8.5 \pm 0.1$ (closed squares). The americium/neodymium was added initially (day 0$)$ as ${ }^{241} \mathrm{Am}^{3+} / \mathrm{Nd}^{3+}$; initial $\left({ }^{241} \mathrm{Am}^{3+}+\right.$ $\mathrm{Nd}^{3+}$ ) concentrations were $2.3 \times 10^{-4} \mathrm{M}(\mathrm{pH} 6), 2.3 \times 10^{-4} \mathrm{M}(\mathrm{pH} 7)$, and $2.3 \times 10^{-4} \mathrm{M}(\mathrm{pH}$ 8.5). Undersaturation experiments at $\mathrm{pH} 6.0$ (open circles), $\mathrm{pH} 7.0$ (open triangles), and $\mathrm{pH} 8.5$ (open squares) were started with precipitates obtained in the supersaturation experiments at their respective $\mathrm{pH}$ values. 
Results for americium/neodymium filtration experiments at $25^{\circ} \mathrm{C}$ are shown in Figures 22,23 , and 24, and results for $60^{\circ} \mathrm{C}$ are shown in Figure 25. The filtration experiments are described in section 4.5 .

At $25^{\circ} \mathrm{C}$, the results show that for $\mathrm{pH} 6$ and $\mathrm{pH} 7$ (Figures 22 and 23) we found that the filters absorbed some of the neodymium/americium solution species, whereas at $\mathrm{pH} 8.5$, the $\mathrm{Nd} / 241 \mathrm{Am}$ solution did not sorb on the filter (Figure 24). The volume required for filter saturation seems to depend on the running time of the experiments. At day 12 , about $1500 \mu \mathrm{L}$ presaturation volume was sufficient while at the other days about $2500 \mu \mathrm{L}$ were necessary. This is not surprising because the dominant solution species might have changed with time thus having different sorption characteristics.

Filtration experiments on day one of the $60^{\circ} \mathrm{C}$ oversaturation experiments at $\mathrm{pH} 6,7$, and 8.5 are shown in Figure 25. At $60^{\circ} \mathrm{C}$, the $\mathrm{pH} \mathrm{6,7}$, and 8.5 experiments required 500, 1500, and $2500 \mu \mathrm{L}$, respectively, as preconditioning volumes. At this temperature, the $\mathrm{pH} 8.5$ experiment required the largest preconditioning volume to saturate the filter. The $\mathrm{pH} 6$ and 7 experiments showed lower sorption and required smaller prefiltering volumes during sampling.

Although sorption behavior as a function of $\mathrm{pH}$ reversed itself when comparing the $25^{\circ}$ and $60^{\circ}$ $\mathrm{C}$ experiments, one dependence was evident at both temperatures, the dependence on the aqueous americium/neodymium concentration. In the $25^{\circ} \mathrm{C}$ experiments at $\mathrm{pH} 6$ and 7 , the volume required to saturate the filter increased with time. In that same time, however, the solubility of the americium/ neodymium decreased. At $\mathrm{pH} 8.5$ and $25^{\circ} \mathrm{C}$, we found little or no evidence of sorption, but the americium/neodymium solubility was quite high. In the $60^{\circ} \mathrm{C}$ experiments, the largest amount of sorption occurred in the $\mathrm{pH} 8.5$ experiment, and the amount of sorption decreased with $\mathrm{pH}$. But this decrease in sorption coincides with an increase in aqueous americium/neodymium concentration. Toward the end of the $60^{\circ} \mathrm{C}$ experiments, as concentrations dropped to $10^{-8}$ to $10^{-10} \mathrm{M}$, we routinely used $2500 \mu \mathrm{L}$ as a presaturation volume for all experiment to ensure adequate saturation of the filters before sampling.

These filtration experiments show that the effectiveness of the phase separation for concentration assays must be monitored during the entire solubility experiment and not only at the beginning because the solution species and their sorption behavior seem to change with time and/or aqueous concentration. 


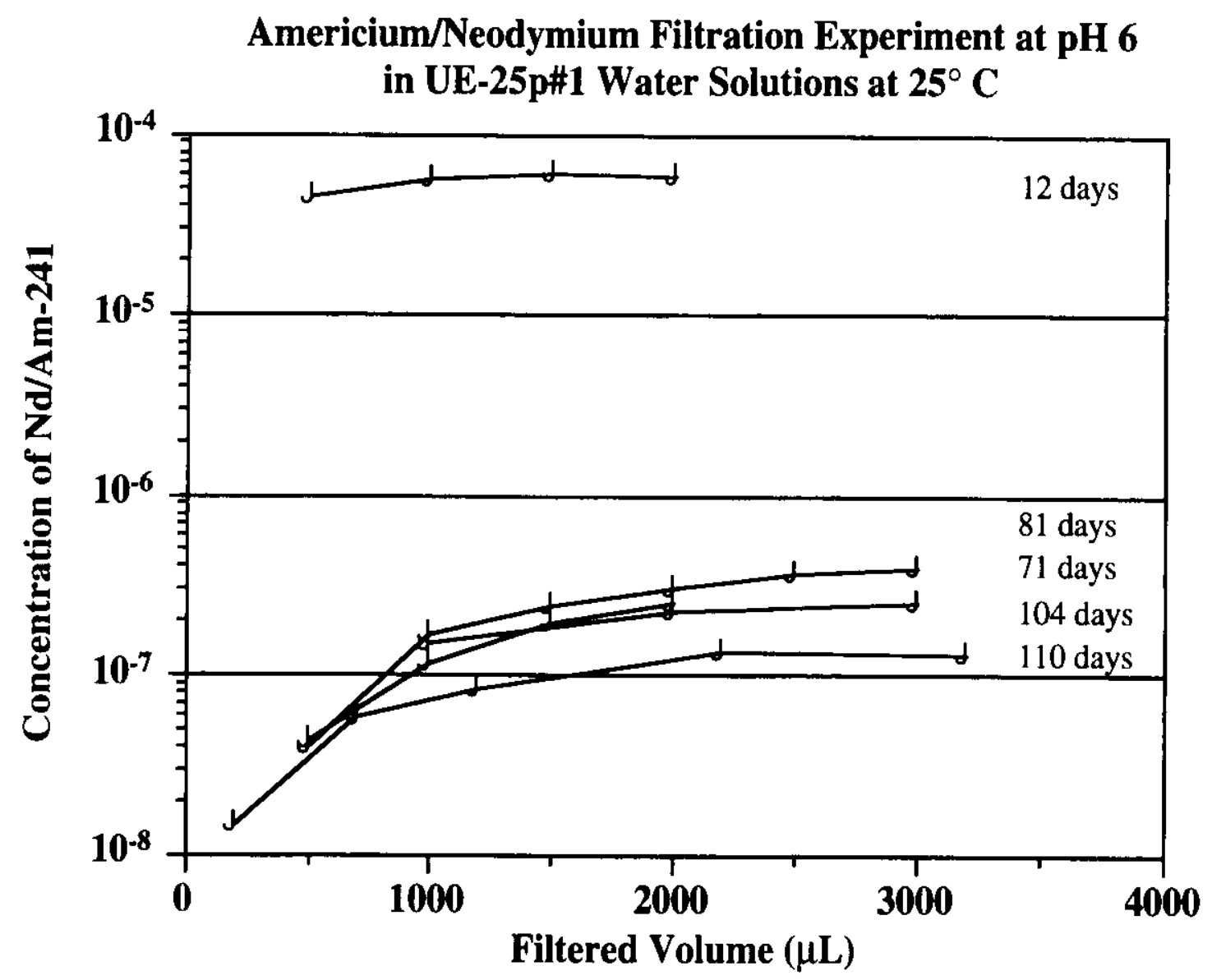

Figure 22. Results of $\mathrm{Am} / \mathrm{Nd}$ filtration experiments at $25^{\circ} \mathrm{C}$ and $\mathrm{pH} 6$. 


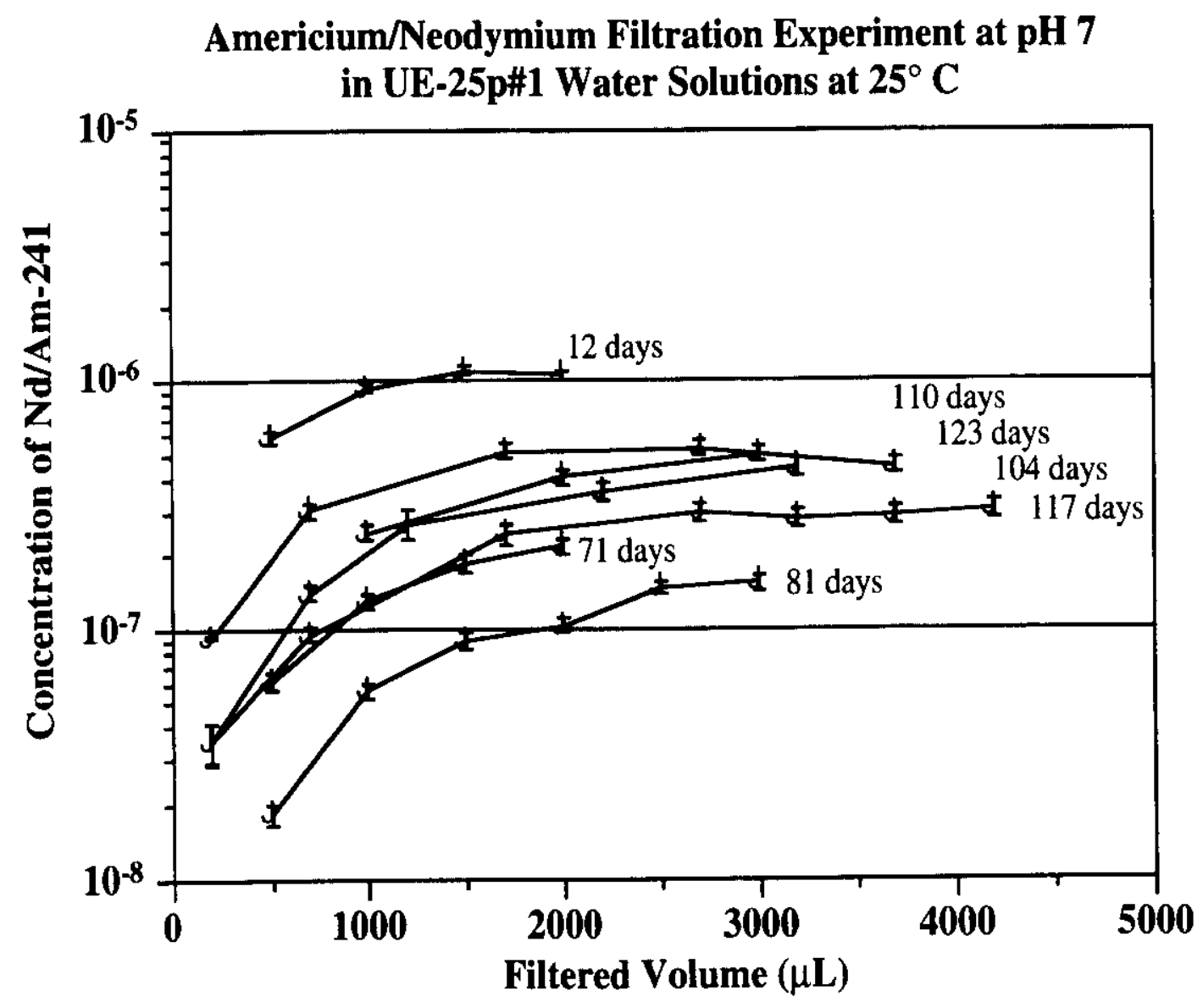

Figure 23. Results of Am/Nd filtration experiments at $25^{\circ} \mathrm{C}$ and $\mathrm{pH} 7$. 
Americium/Neodymium Filtration Experiment at pH 8.5 in UE-25p\#1 Water Solutions at $25^{\circ} \mathrm{C}$

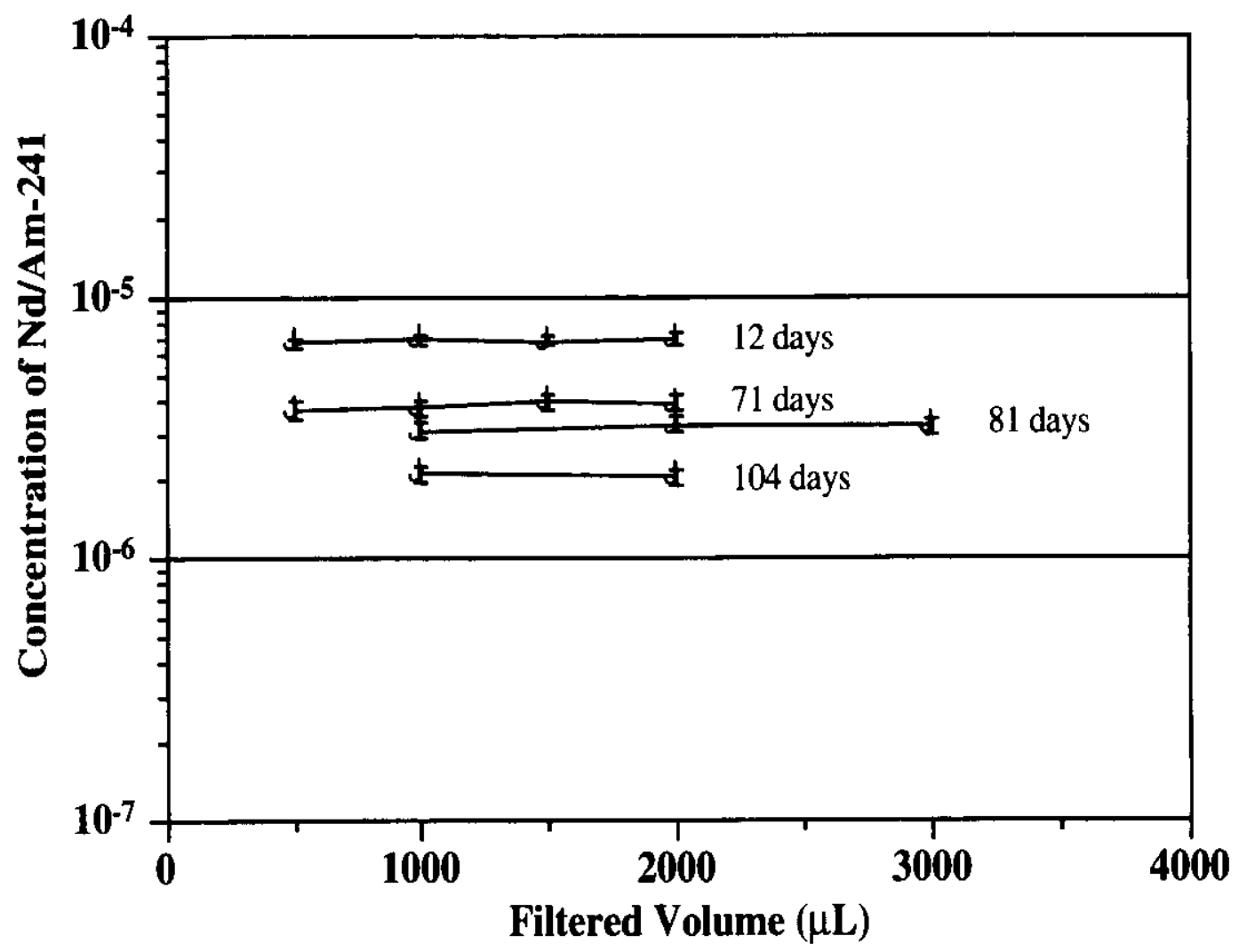

Figure 24. Results of $\mathrm{Am} / \mathrm{Nd}$ filtration experiments at $25^{\circ} \mathrm{C}$ and $\mathrm{pH} 8.5$. 


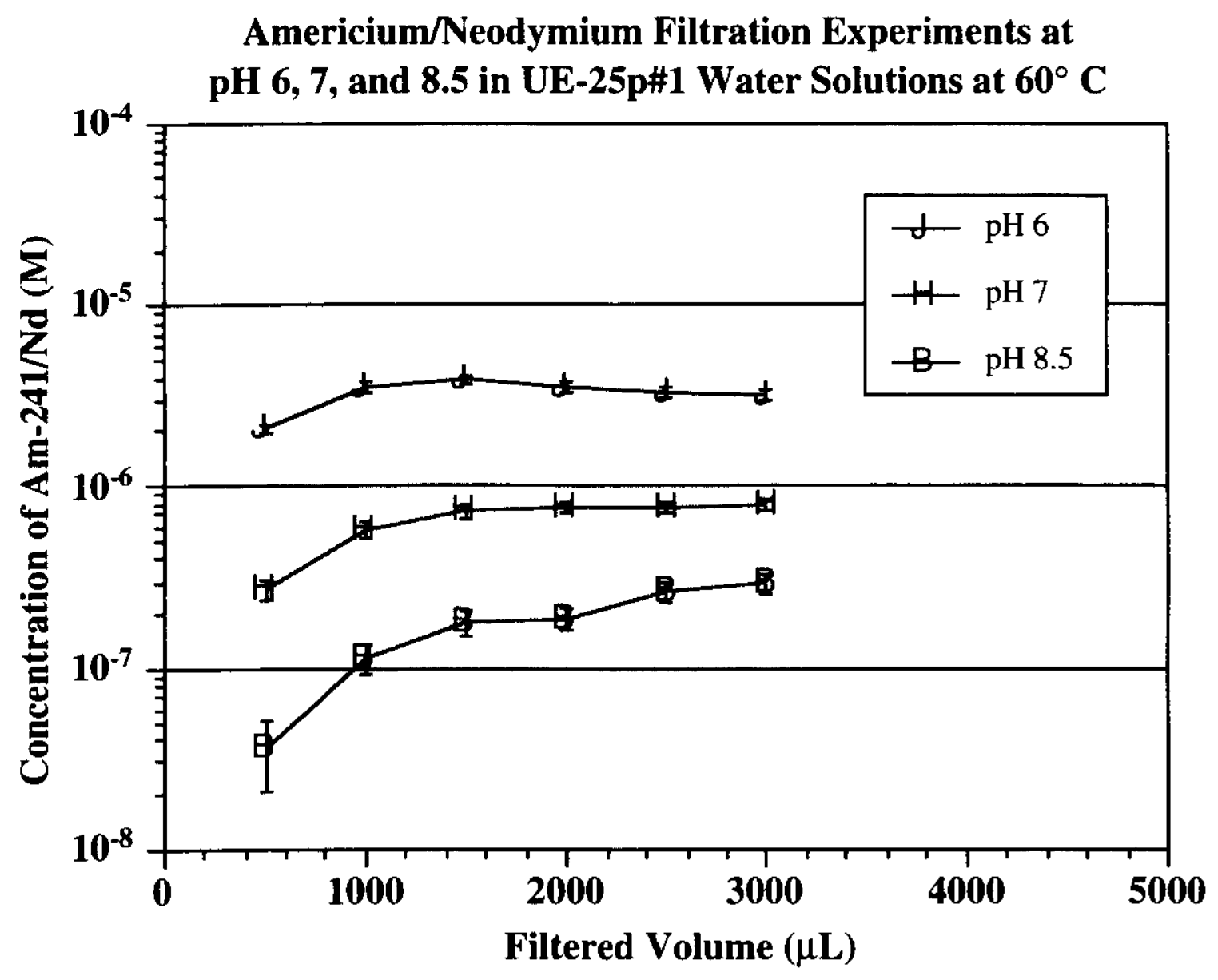

Figure 25. Results of initial $\mathrm{Am} / \mathrm{Nd}$ filtration experiments at $60^{\circ} \mathrm{C}$ and $\mathrm{pH} 6,7$, and 8.5 conducted 1 day after the start of the experiments.

In summary, the solubility of americium/neodymium decreased significantly with increasing temperature and increased somewhat with increasing $\mathrm{pH}$.

\subsubsection{Speciation}

Speciation measurements could not be carried out because of the low solution concentrations. The trivalent neodymium cannot change its oxidation state. We determined whether the ${ }^{241} \mathrm{Am}$ tracer undergoes a change in oxidation state. We used extractions with $0.5 \mathrm{M}$ thenoyltrifluoroacetone (TTA) or 0.025 M 1-phenyl-3-methyl-4-benzoy-pyrazolin-5-one (PMBP) at $\mathrm{pH} 0$ and coprecipitations with $\mathrm{LaF}_{3}$ for this test. TTA or PMBP extracts the oxidation state IV and leaves the oxidation states III, $\mathrm{V}$, and VI in the aqueous solution. The lanthanum fluoride (with holding oxidant) coprecipitates the 


\subsubsection{Identification of Solids}

The neodymium/americium-241 precipitates found in the experiments at $25^{\circ}$ and $60^{\circ} \mathrm{C}$ were collected by centrifugation, washed with a small amount of $\mathrm{CO}_{2}$-free water, dried with an argon jet, and analyzed by $x$-ray powder diffraction. The $d$-spacings and relative intensities of all of the solids obtained are listed in Table XXII. All of the solids appear to be very similar to one another with the exception of the solid from the $\mathrm{pH} 6$ experiment at $25^{\circ} \mathrm{C}$; the powder patterns share many of the same d-spacings between 4.9 and $2.0 \AA$.

Table XXIII lists the X-ray powder diffraction patterns of the solids from the $\mathrm{pH} 6,7$, and 8.5 solubility experiments at $25^{\circ} \mathrm{C}$ together with reference patterns of: $1 . \mathrm{Nd}_{2}\left(\mathrm{CO}_{3}\right)_{3} \bullet 2 \mathrm{H}_{2} \mathrm{O}, 2$. hexagonal $\mathrm{NdOHCO}_{3}$, and 3. orthorhombic $\mathrm{NdOHCO}_{3}$. It was shown in the literature that americium hydroxycarbonates are isostructural to the analogous neodymium hydroxycarbonates. $40,42,43$ The solid obtained in the $\mathrm{pH} 6$ experiment at $25^{\circ} \mathrm{C}$ appears to be hexagonal $\mathrm{NdOHCO}_{3}$. The number of diffraction lines in the powder pattern as well as their d-spacings agree very well. In addition to some very strong lines with d-spacings larger than $5 \AA$, the precipitates from the $\mathrm{pH} 7$ and 8.5 experiments have a greater number of diffraction lines between 4.9 and $2.0 \AA$. Most of these lines are not found in the reference pattern for hexagonal $\mathrm{NdOHCO}_{3}$, but are associated with the patterns of both $\mathrm{Nd}_{2}\left(\mathrm{CO}_{3}\right)_{3} \cdot 2 \mathrm{H}_{2} \mathrm{O}$ and orthorhombic $\mathrm{NdOHCO}_{3}$. D-spacings at $4.24 \AA$ in the $\mathrm{pH} 7$ solid and at $4.35 \AA$ in the $\mathrm{pH} 8.5$ solid closely match the medium and strong lines at 4.24 and $4.28 \AA$ found only in the powder pattern for orthorhombic $\mathrm{NdOHCO}_{3}$; whereas, $\mathrm{d}$-spacings at $3.03 \AA$ and near $2.8 \AA$ found in both the $\mathrm{pH} 7$ and $\mathrm{pH} 8.5$ powder patterns very closely match lines at 3.02 and $2.87 \AA$ found only in $\mathrm{Nd}_{2}\left(\mathrm{CO}_{3}\right)_{3} \cdot 2 \mathrm{H}_{2} \mathrm{O}$. As for the strong diffraction lines with d-spacings above $6 \AA$ in the $\mathrm{pH} 7$ and 8.5 solids, the only reference pattern with a strong diffraction line at a d-spacing larger than $6 \AA$ is that of $\mathrm{Nd}_{2}\left(\mathrm{CO}_{3}\right)_{3} \cdot 2 \mathrm{H}_{2} \mathrm{O}$. We found with the published powder patterns for hydrated neptunium solids that strong lines with large $\mathrm{d}$-spacings were influenced by varying hydrate content in the solid. If the solids from the $\mathrm{pH} 7$ and 8.5 experiments contained $\mathrm{Nd}_{2}\left(\mathrm{CO}_{3}\right)_{3}$ with a varying hydrate content and the diffraction characteristic of hydrate water behaves as it does in neptunium solids, then we may in fact see some diffraction lines at d-spacings greater than 10-12 $\AA$. The only conlusion we can draw at this point regarding the solids produced in the $\mathrm{pH} 7$ and 8.5 solubility experiments at $25^{\circ} \mathrm{C}$, is that they appear to be mixtures of orthorhombic $\mathrm{NdOHCO}_{3}$ and $\mathrm{Nd}_{2}\left(\mathrm{CO}_{3}\right)_{3} \cdot 2 \mathrm{H}_{2} \mathrm{O}$ with possibly varying water content.

Table XXIV lists the X-ray powder diffraction patterns of the solids from the $\mathrm{pH} 6,7$, and 8.5 solubility experiments at $60^{\circ} \mathrm{C}$ together with reference patterns of: $1 . \mathrm{Nd}_{2}\left(\mathrm{CO}_{3}\right)_{3} \cdot 2 \mathrm{H}_{2} \mathrm{O}, 2$. hexagonal $\mathrm{NdOHCO}_{3}$, and 3. orthorhombic $\mathrm{NdOHCO}_{3}$. The powder patterns at $\mathrm{pH} 6,7$, and 8.5 and $60^{\circ} \mathrm{C}$ match the respective powder patterns at $\mathrm{pH} 6,7$, and 8.5 and $60^{\circ} \mathrm{C}$. The solid from the pH 6 experiment only contained three diffraction lines. The strongest of the three lines was at $2.86 \AA$ which matches a line found in both the powder pattern for the solid from the $\mathrm{pH} 6$ experiment at $25^{\circ} \mathrm{C}$ and the powder pattern for hexagonal $\mathrm{NdOHCO}_{3}$. The weak diffraction line at $3.06 \AA$ may correspond to one of the two lines in the pattern for $\mathrm{Nd}_{2}\left(\mathrm{CO}_{3}\right)_{3} \cdot 2 \mathrm{H}_{2} \mathrm{O}$ which are at 3.09 and $3.02 \AA$. At best, we can say that the solid that formed 
in the $\mathrm{pH} 6$ experiment at $60^{\circ} \mathrm{C}$, may be a slightly crystalline mixture of $\mathrm{Nd}_{2}\left(\mathrm{CO}_{3}\right)_{3} \cdot 2 \mathrm{H}_{2} \mathrm{O}$ and hexagonal $\mathrm{NdOHCO}_{3}$. Regarding the $\mathrm{pH} 7$ and 8.5 solids obtained at $60^{\circ} \mathrm{C}$, their powder patterns very much resemble those obtained in the $\mathrm{pH} 7$ and 8.5 experiments at $25^{\circ} \mathrm{C}$, so they too appear to be mixtures of orthorhombic $\mathrm{NdOHCO}_{3}$ and $\mathrm{Nd}_{2}\left(\mathrm{CO}_{3}\right)_{3} \cdot 2 \mathrm{H}_{2} \mathrm{O}$ with possibly varying water content.

In summary, the UE-25p \# 1 solubility experiments at $\mathrm{pH} 6$ appear to have produced hexagonal $\mathrm{NdOHCO}_{3}$ at $25^{\circ} \mathrm{C}$ and possibly a mixture of $\mathrm{Nd}_{2}\left(\mathrm{CO}_{3}\right)_{3} \cdot 2 \mathrm{H}_{2} \mathrm{O}$ and hexagonal $\mathrm{NdOHCO}_{3}$ at $60^{\circ} \mathrm{C}$; whereas, experiments at $\mathrm{pH} 7$ and 8.5 produced mixtures of orthorhombic $\mathrm{NdOHCO}$ and $\mathrm{Nd}_{2}\left(\mathrm{CO}_{3}\right)_{3}$ - $2 \mathrm{H}_{2} \mathrm{O}$ at both $25^{\circ}$ and $60^{\circ} \mathrm{C}$.

\section{Acknowledgement}

This work was prepared by Yucca Mountain Site Characterization Project (YMP) participants as part of the U.S. Civilian Radioactive Waste Management Program. The Yucca Mountain Site Characterization Project (YMP) is managed by the U.S. Department of Energy/YMP. This work was performed at the Lawrence Berkeley Laboratory (LBL) for the Los Alamos National Laboratory (Los Alamos). The Lawrence Berkeley Laboratory is operated by the University of California for the U.S. Department of Energy under Contract DE-AC-03-76SF00098. In compliance with AP-5.1Q the Los Alamos Data Tracking Number for this record package segment is LA000000000072.001. 
Table XXII. X-ray powder diffraction patterns of $\mathrm{Nd} /{ }^{241} \mathrm{Am}$ solid phases in UE-25p \#1 groundwater at $25^{\circ}$ and $60^{\circ} \mathrm{C}$ and $\mathrm{pH} 6,7$, and 8.5 .

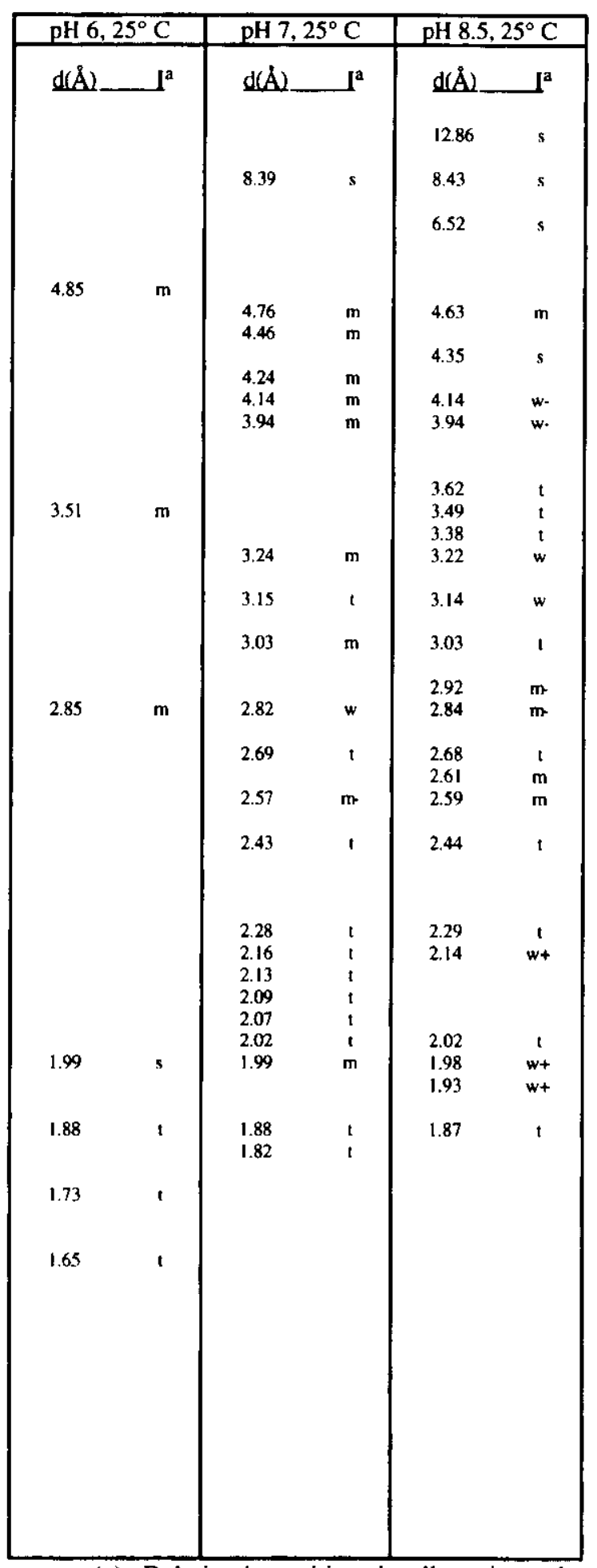

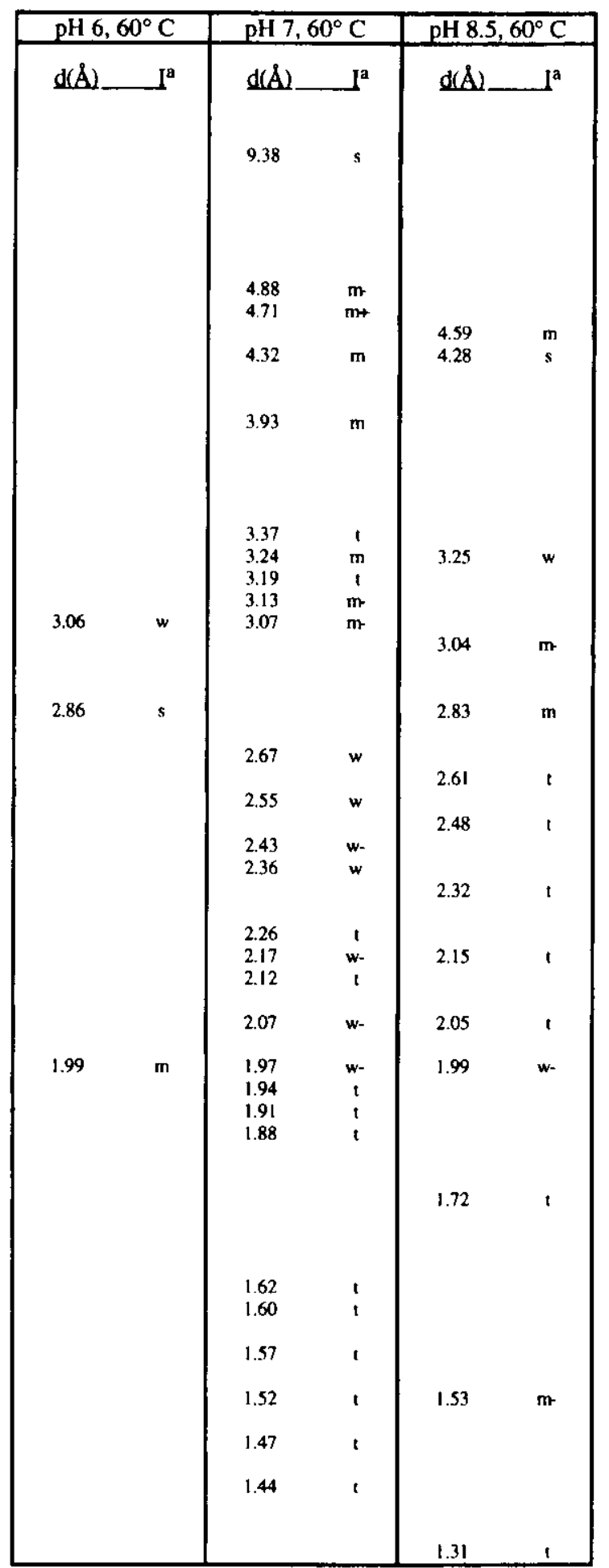

(a) Relative intensities visually estimated: $v s=$ very strong, $s=$ strong, $m=$ medium, $w=$ weak, $t=$ trace. 
Table XXIII. X-ray powder diffraction patterns of $\mathrm{Nd} /{ }^{241} \mathrm{Am}$ solid phases in UE-25p \#1 groundwater at $25^{\circ} \mathrm{C}$ and $\mathrm{pH} 6,7$, and 8.5 compared with reference patterns of: $1 . \mathrm{Nd}_{2}\left(\mathrm{CO}_{3}\right)_{3}$ - $2 \mathrm{H}_{2} \mathrm{O}, 2$. hexagonal $\mathrm{NdOHCO}_{3}$, and 3. orthorhombic $\mathrm{NdOHCO}_{3} \cdot{ }^{40,42,43}$

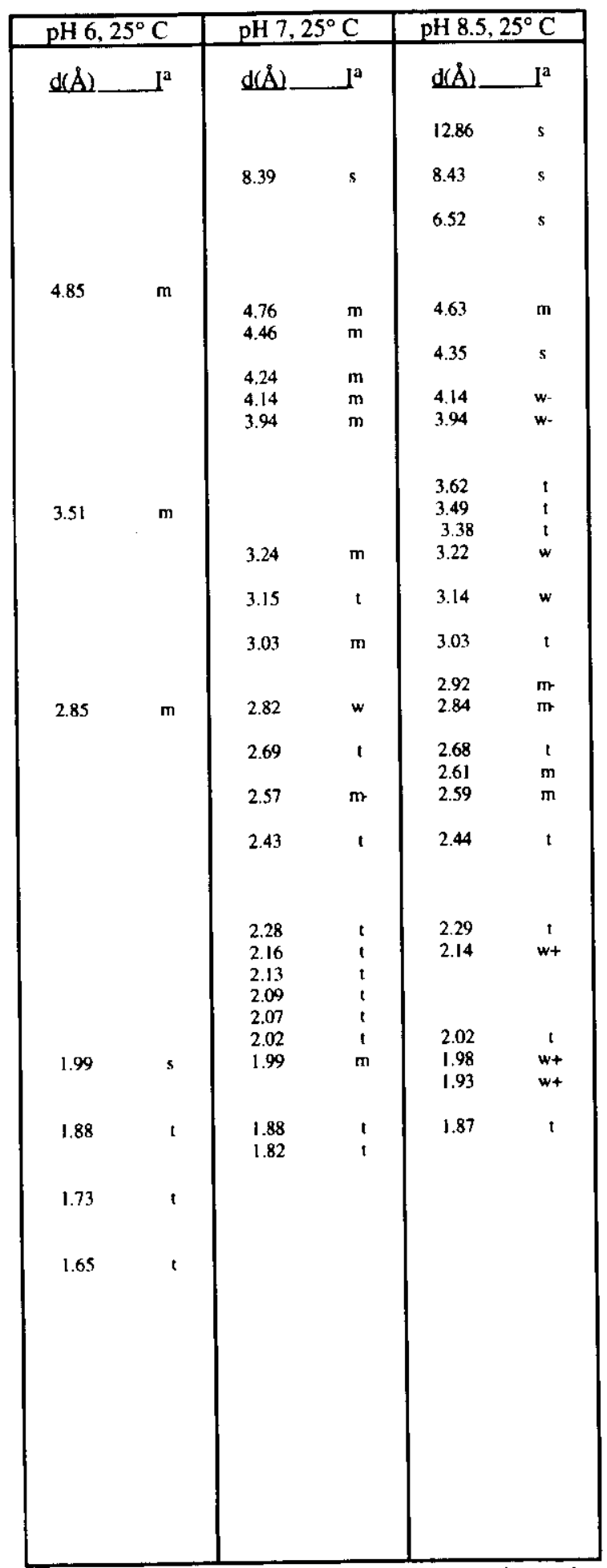

\begin{tabular}{|c|c|c|c|c|c|}
\hline \multicolumn{2}{|c|}{ Ref.\#! } & \multicolumn{2}{|c|}{ Ref. \#2 } & \multicolumn{2}{|c|}{ Ref. \#3 $3^{(b)}$} \\
\hline $\mathrm{d}(\AA ̊)$ & $\perp^{a}$ & $\mathrm{~d}(\AA)$ & & $\mathrm{d}(\AA ̊)$ & $\perp^{a}$ \\
\hline 7.56 & $\mathbf{m}$ & & & & \\
\hline 5.68 & $s$ & & & 5.50 & $\mathbf{m}$ \\
\hline 4.67 & $\mathrm{~s}$ & 4.96 & m & & \\
\hline & & & & $\begin{array}{l}4.28 \\
4.24\end{array}$ & $\begin{array}{l}\text { m } \\
\text { vs }\end{array}$ \\
\hline 3.93 & s & & & & \\
\hline & 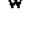 & & & 3.68 & $t$ \\
\hline 3.62 & $m$ & 3.57 & $s$ & 3.65 & $\mathrm{~m}$ \\
\hline & & & & 3.32 & $\mathrm{~m}$ \\
\hline 3.09 & $s$ & & & & \\
\hline $\begin{array}{l}3.02 \\
2.98\end{array}$ & $\begin{array}{l}s \\
w\end{array}$ & & & 2.94 & $t$ \\
\hline & & 2.90 & s & 2.91 & $\mathrm{~m}$ \\
\hline 2.75 & $w$ & & & 2.75 & $\mathbf{m}$ \\
\hline & & & & 2.63 & $\mathrm{~m}$ \\
\hline 2.58 & s & 2.49 & $w$ & $\begin{array}{l}2.48 \\
2.40\end{array}$ & s \\
\hline & & & & $\begin{array}{l}2.32 \\
2.31\end{array}$ & $\begin{array}{l}w \\
\text { m }\end{array}$ \\
\hline 2.25 & $w$ & & & & \\
\hline 2.17 & $w$ & & & $\begin{array}{l}2.14 \\
2.12 \\
2.10\end{array}$ & $\begin{array}{l}w \\
s \\
\text { t }\end{array}$ \\
\hline 2.08 & $w$ & 2.06 & $\mathbf{m}$ & 2.05 & $w$ \\
\hline 2.02 & $m$ & 2.04 & m & 2.03 & $w$ \\
\hline 1.98 & $w$ & & & 1.96 & $\mathbf{w}$ \\
\hline & & 1.90 & $\mathrm{~m}$ & & \\
\hline 1.87 & $\mathrm{~m}$ & & & 1.88 & 1 \\
\hline 1.83 & $\mathrm{~m}$ & & & 1.83 & $\mathbf{s}$ \\
\hline 1.78 & m & 1.78 & 1 & 1.81 & $w$ \\
\hline 1.74 & w & & & 1.72 & $w$ \\
\hline & & 1.68 & $w$ & $\begin{array}{l}1.09 \\
1.68\end{array}$ & t \\
\hline & & & & 1.66 & 1 \\
\hline & & & & 1.62 & w \\
\hline & & 1.59 & $w$ & 1.58 & t \\
\hline 1.56 & m & & & 1.57 & $w$ \\
\hline & & & & $\begin{array}{l}1.54 \\
1.52\end{array}$ & $\begin{array}{l}m \\
w\end{array}$ \\
\hline & & 1.50 & w & 1.50 & 1 \\
\hline & & & & 1.47 & w \\
\hline & & 1.45 & 1 & $\begin{array}{l}1.46 \\
1.44\end{array}$ & w \\
\hline & & & & 1.42 & i \\
\hline & & 1.35 & $t$ & 1.37 & $t$ \\
\hline
\end{tabular}

(a) Relative intensities visually estimated: vs = very strong, $\mathrm{s}=$ strong, $\mathrm{m}=$ medium, $\mathrm{w}=$ weak, $\mathrm{t}=$ trace.

(b) Ref. \#3 contains 7 more "weak" and "trace" lines with d-spacings smaller than $1.31 \AA$ that are not listed. 
Table XXIV. X-ray powder diffraction patterns of $\mathrm{Nd} / 241 \mathrm{Am}$ solid phases in UE-25p \#1 groundwater at $60^{\circ} \mathrm{C}$ and $\mathrm{pH} 6,7$, and 8.5 compared with reference patterns of: $1 . \mathrm{Nd}_{2}\left(\mathrm{CO}_{3}\right)_{3}$ - $2 \mathrm{H}_{2} \mathrm{O}$, 2. hexagonal $\mathrm{NdOHCO}_{3}$, and 3. orthorhombic $\mathrm{NdOHCO}_{3} \cdot{ }^{40,42,43}$

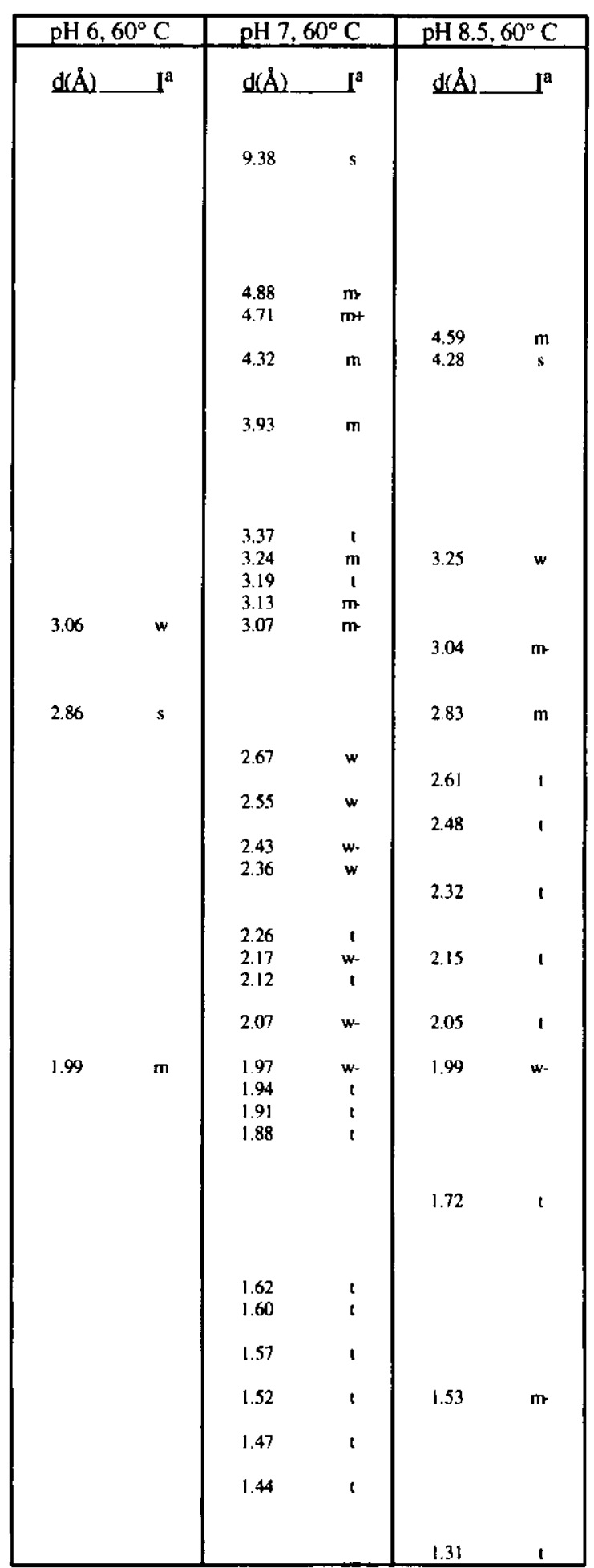

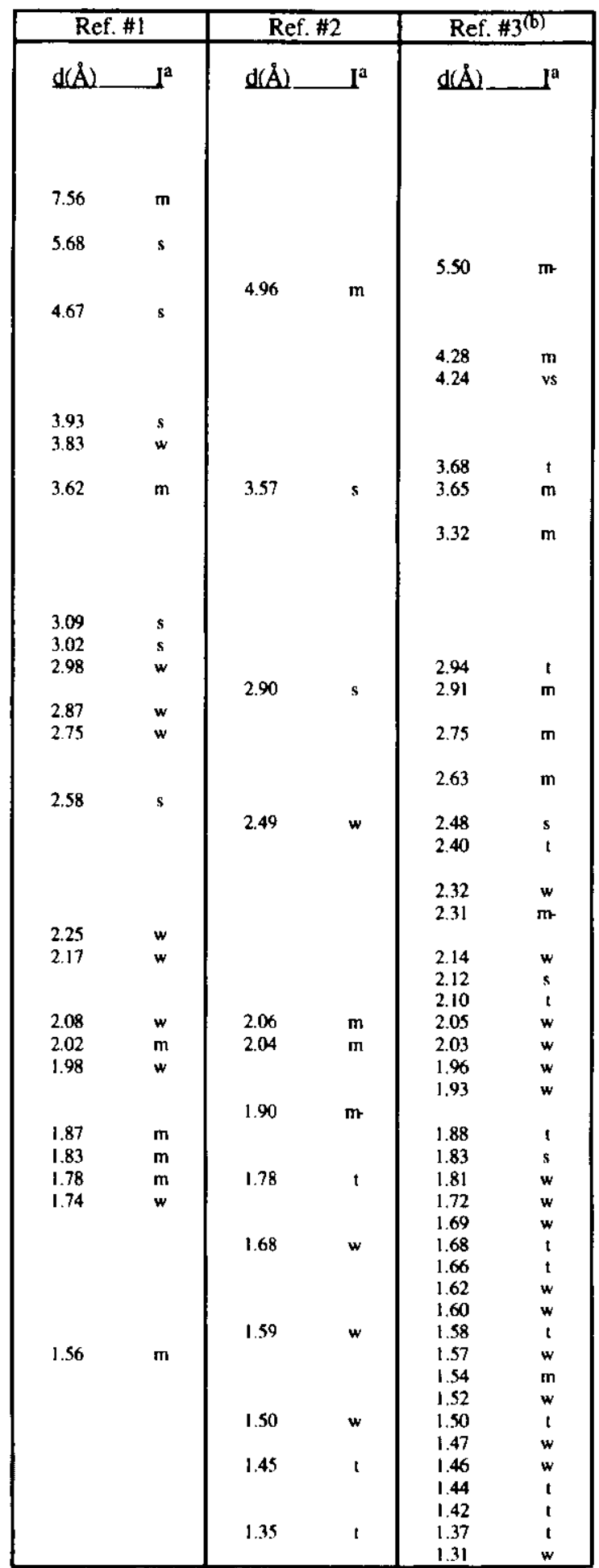

(a) Relative intensities visually estimated: vs = very strong, $s=$ strong, $m=$ medium, $w=$ weak, $l=$ trace.

(b) Ref. \#3 contains 7 more "weak" and "trace" lines with d-spacings smaller than $1.31 \AA$ that are not listed. 


\section{REFERENCES}

1. H. Nitsche, R.C. Gatti, E.M. Standifer, S.C. Lee, A. Müller, T. Prussin, R.S. Deinhammer, H. Mauer, K. Becraft, S. Leung, and S.A. Carpenter, "Measured Solubilities and Speciations of Neptunium, Plutonium, and Americium in a Typical Groundwater (J-13) from the Yucca Mountain Region," report LBL-30958, Milestone Report 3010, Lawrence Berkeley Laboratory, California (1992). NNA.930507.0136

2. U.S. Department of Energy Yucca Mountain Site Characterization Plan, Yucca Mountain Site, Nevada Research and Development Area, Nevada, Office of Civilian Radioactive Waste Management, Washington, D.C. (1988). HQO.881201.0002

3. D.J. Brooks and J.A. Corrado, "Determination of Radionuclide Solubility in Groundwater for Assessment of High-Level Waste Isolation,” U.S. Nuclear Regulatory Commission, Technical Position, Washington, D.C. (1984). NNA.871104.0035

4. A.E. Ogard and J.F. Kerrisk, "Groundwater Chemistry Along the Flow Path between a Proposed Repository Site and the Accessible Environment," report LA10188-MS, Los Alamos National Laboratory, New Mexico (1984). NNA.870406.0021

5. J.K. Johnstone, R.R. Peters, and P.F. Gnirk, "Unit Evaluation of Yucca Mountain, Nevada Test Site: Summary Report and Recommendations," report SAND-83-0372, Sandia National Laboratories, Albuquerque, New Mexico (1984). NNA.870519.0052

6. B.V. Enüstün, J. Turevich, "Solubility of Fine Particles of Strontium Sulfate," J. Amer. Chem. Soc. 82,4502-4509 (1960). NNA.930326.0103

7. P.W. Vorhees, "The Theory of Ostwald Ripening" J. Stat. Phys. 38, $231-252$ (1985). NNA.930326.0102

8. J.W. Morse, W.H. Casey, "Ostwald Processes and Mineral Paragenesis in Sediments" Amer. J. Sci. 288, 537-560 (1980). NNA.930326.0101

9. J.A. Rard, "The Effect of Precipitation Conditions and Aging upon Characteristics of Particles Precipitated from Aqueous Solutions," report UCID-21755, Lawrence Livermore National Laboratory, Livermore, California, U.S.A. (1989). NNA.930406.0024 
10. R. Stumpe, J.I. Kim, W. Schrepp, H. Walter, "Speciation of Actinide Ions in Aqueous Solution by Laser Induced Photoacoustic Spectroscopy," Appl. Phys. B 34, 203-206 (1984). HQS.880517.2551

11. F.T. Ewart, M. Liezers, J.W. McMillan, P.M. Pollard, H.P. Thomason, "The Development of a Laser Induced Photoacoustic Facility for Actinide Speciation," report NSS/R103, Harwell Laboratory, Oxfordshire, U.K. (1988). HQX.880701.0010

12. J.E. Cross, D. Crossley, J.W. Edwards, P.M. Pollard, S. Turner, "Actinide Speciation. Further Development and Application of Laser Induced Photoacoustic Spectroscopy and Voltammetry," report NSS/R1 19, Harwell Laboratory, Oxfordshire, U.K. (1989). HQX.891211.0040

13. R.A. Torres, C.E. Palmer, P.A. Baisden, R.E. Russo, R.J. Silva, “A Comparison of Photoacoustic Spectroscopy, Conventional Absorption Spectroscopy, and Potentiometry as Probes of Lanthanide Speciation," report UCRL-101760, Lawrence Livermore National Laboratory, Livermore, California, U.S.A. (1989). NNA.930326.0100

14. M.M. Doxtader, V.A. Maroni, J.V. Beitz, M. Heaven, "Laser Photoacoustic Spectroscopy for Trace Level Detection of Actinides in Groundwater," Mat. Res. Soc. Symp. Proc. 84, 173-185 (1987). NNA.930420.0099

15. H. Nitsche, S.C. Lee, R.C. Gatti, "Determination of Plutonium Oxidation States at Trace Levels Pertinent to Nuclear Waste Disposal," J. Radioanal. Nucl. Chem. 124(l), 171-185 (1988). NNA.930326.0099

16. D.B. Tucker, E.M. Standifer, H. Nitsche, and R.J. Silva, "Data Acquisition and Feedback Control System for Solubility Studies of Nuclear Waste Elements, Lanthanide and Actinide Research 2, 279-287 (1988). NNA.930326.0096

17. H. Nitsche and N.M. Edelstein, "Solubilities and Speciation of Selected Transuranium Ions. A Comparison of a Non-Complexing Solution with a Groundwater from the Nevada Tuff Site," Radiochim Acta 39, 23 (1985). NNA.930326.0097

18. D. Cohen, "Electrochemical Studies of Plutonium Ions in Perchloric Acid Solution," J. Inorg. Nucl. Chem. 18, 207 (1961). NNA.930326.0098 
19. G.A. Burney, R.M. Harbour, "Radiochemistry of Neptunium," NAS-NS 3060, Nuclear Science Series, National Academy of Sciences-National Research Council, 22-25 (1974). NNA.930326.0095

20. T.W. Newton, D.E. Hobart, P.D. Palmer, "The Preparation and Stability of Pure Oxidation States of Neptunium, Plutonium, and Americium," report LA-UR-86967, Los Alamos National Laboratory, Los Alamos, New Mexico (1986). NNA.930406.0025

21. D. Cohen, "The Absorption Spectra of Plutonium Ions in Perchloric Acid Solution," J. Inorg. Nucl. Chem. 18, 211 (1961). NNA.930326.0094

22. P.G. Hagan, J.M. Cleveland, "The Absorption Spectra of Neptunium Ions in Perchloric Acid Solution," J. Inorg. Nucl. Chem. 28, 2905 (1966). NNA.930326.0093

23. S.L. Phillips, C.A. Phillips, and J. Skeen, "Hydrolysis, Formation and Ionization Constants at $25^{\circ}$ C, and at High Temperature-High Ionic Strength," Report LBL14996, Lawrence Berkeley Laboratory, University of California, Berkeley, California (1985). NNA.930430.0016

24. The Polymer Corporation, Product Bulletin BR-10 8/84, Reading, PA (1984). NNA. 930406.0029

25. H. Nitsche, R.C. Gatti, and S.C. Lee, "Low-level Determination of Plutonium by Gamma and $L$ X-ray Spectroscopy," Proceedings of International Topical Conference on Methods and Applications of Radioanalytical Chemistry-III, April 21-27, Kona, Hawaii (in press, 1991). NNA.930326.0092

26. R.D. Lindberg and D.D. Runnells, "Ground Water Redox Reactions: An Analysis of Equilibrium State Applied to Eh Measurements and Geochemical Modeling," Science 225, No. 4665, 925 927 (1984).

27. R.M. Garrels, Mineral Equilibria at Low Temperature and Pressure, Harper and Brothers, New York, N.Y. (1960). Readily Available.

28. D. Langmuir, "Eh-pH Determinations," in Procedures in Sedimentary Petrology, R.E. Carver, ed., 597-635, Wiley, New York, N.Y. (1971). Readily Available.

29. H. Nitsche, E.M. Standifer, and R.J. Silva, "Neptunium(V) Complexation with Carbonate," Lanthanide and Actinide Research 3, 203-211 (1990). NNA.930406.0027 
30. Y.F. Volkov, G.L Visyashcheva, S.V.Tomilin, V.I. Spiryakov, I.I. Kapshukov, and A.G. Rykov, "Carbonate Compounds of Pentavalent Actinides with Alkali Metal Cations VII. Synthesis and Crystal Structure of Hydrate Compounds with the Composition $\mathrm{Na}_{0.6} \mathrm{NpO}_{2}\left(\mathrm{CO}_{3}\right)_{0.8} \bullet \mathrm{nH}_{2} 0$," Sov. Radiochem. (Eng. transl.) 21, 583-590 (1979). NNA.930420.0098

31. Y.F. Volkov, G.I. Visyashcheva, S.V. Tomilin, I.I. Kapshukov, and R.G. Rykov, "Study of Carbonate Compounds of Pentavalent Actinides with Alkali-Metal Cations. VIII. Synthesis and X-Ray Diffraction Investigation of Several Compounds of Neptunium(V) with Sodium and Rubidium," Sov. Radiochem. (Eng. transl.) 23, 191-195 (1981). NNA.930326.0091

32. Y.F. Volkov, G.I. Visyashcheva, and I.I. Kapshukov, "Study of Carbonate Compounds of Pentavalent Actinides with Alkali-Metal Cations. V. Production and Indentification of Hydrate Forms of Sodium Monocarbonato-neptunylate ," Sov. Radiochem. (Eng. transl.) 19, 263-266 (1977). NNA.930326.0089

33. Y.F. Volkov, S.V. Tomilin, G.I. Visyashcheva, I.I. and Kapshukov, "Carbonate Compounds of Pentavalent Actinoids with Alkali-Metal Cations. VI. X-Ray Structure Analysis of $\mathrm{LiNpO}_{2} \mathrm{CO}_{3}$ and $\mathrm{NaNpO}_{2} \mathrm{CO}_{3}$," Sov. Radiochem. (Eng. transl.) 21, 579-583 (1979). NNA.930326.0090

34. M.P. Neu, D.C. Hoffman, K.E. Roberts, H. Nitsche, and R.J. Silva, "Comparison of Extractions and Laser Photoacoustic Spectroscopy for the Determination of Plutonium Species in Carbonate Solution," manuscript in preparation (1993).

35. G.L. Silver, "Suggestion for the Determination of Plutonium Valencies in Aqueous Solutions," Radiochem. Radioanal. Lett. 9, 5-6, 315-320 (1972). NNA.930326.0087

36. R.C.L. Mooney and W.H. Zachariasen, The Transuranium Elements Part II, G.T. Seaborg, J.J. Katz, and W.M. Manning, eds., 1442-1447, McGraw-Hill, New York, N.Y. (1949). Readily Available.

37. K.W. Bagnall and J.B. Laidler, "Neptunium and Plutonium Trioxide Hydrates," J. Chem. Soc., 2693-2696 (1964). NNA.930326.0084

38. F.H. Ellinger and W.H. Zachariasen, "The Crystal Structure of $\mathrm{KPuO}_{2} \mathrm{CO}_{3}, \mathrm{NH}_{4} \mathrm{PuO}_{2} \mathrm{CO}_{3}$ and $\mathrm{RbAmO}_{2} \mathrm{CO}_{3}$," J. Phys. Chem. 58, 405-408 (1954). NNA.930326.0082 
39. J. Navratil and Bramlet, "Preparation and Characterization of Plutonyl(VI) Carbonate," J. Inorg. Nucl. Chem. 35, 157-163 (1973). NNA.930326.0083

40. R.J. Silva and H. Nitsche, "Thermodynamic Properties of Chemical Species of Waste Radionuclides," Report NUREG/CP-0052, U.S. Nuclear Regulatory Commission, Washington, D.C. (1983). HQS.880517.206

41. R.D. Shannon, "Revised Effective Ionic Radii and Systematic Studies of Interatomic Distances in Halogennides and Chalcogenides," Acta Cryst. A 32, 751-767 (1976). NNA.930326.0080

42. E.M. Standifer and H. Nitsche, "First Evidence for Hexagonal $\mathrm{AmOHCO}_{3}$," Lanthanide and Actinide Research 2, 383-384 (1988). NNA.880829.0064

43. H. Dexpert and P. Caro, "Determination de la Structure Cristalline de le Variete A des Hydroxycarbonates de Terres Rares $\mathrm{LnOHCO}_{3}(\mathrm{Ln}=\mathrm{Nd})$," Mat. Res. Bull, 9, 1577-1586(1974). NNA.930406.0030 


\section{APPENDIX A}

\section{RESULTS OF NEPTUNIUM SOLUBILITY EXPERIMENTS}

IN UE-25p \#1 WATER 
Appendix IA. Results of Neptunium solubility experiments in UE25p \#1 water at $25^{\circ} \mathrm{C}$ and $\mathrm{pH} 6.0$

\begin{tabular}{lclc}
\multicolumn{1}{c}{ Sample I.D. } & Days & $\mathrm{pH}$ & Concentration $(\mathrm{M})$ \\
\hline Initial amount added & 0 & - & $4.8 \times 10^{-3}$ \\
1-1A1U2 & 1 & 6.12 & $(3.92 \pm 0.14) \times 10^{-3}$ \\
1-2A1U2 & 4 & 5.98 & $(3.70 \pm 0.13) \times 10^{-3}$ \\
1-3A1U2 & 9 &.-- & $(3.37 \pm 0.12) \times 10^{-3}$ \\
1-4A1U2 & 11 & 6.00 & $(2.33 \pm 0.08) \times 10^{-3}$ \\
1-5A1U2 & 15 & 6.17 & $(2.02 \pm 0.07) \times 10^{-3}$ \\
1-6A1U2 & 18 & 6.05 & $(2.40 \pm 0.08) \times 10^{-3}$ \\
1-7A2U2 & 22 & 6.11 & $(2.45 \pm 0.09) \times 10^{-3}$ \\
1-8A1U2 & 25 & 5.99 & $(2.49 \pm 0.09) \times 10^{-3}$ \\
1-9A1U2 & 29 & 5.92 & $(2.53 \pm 0.09) \times 10^{-3}$ \\
1-10A2U2 & 36 & 5.78 & $(1.98 \pm 0.07) \times 10^{-3}$ \\
1-11A1U2 & 43 & 6.00 & $(3.38 \pm 0.13) \times 10^{-3}$ \\
1-12A2U2 & 50 & 6.10 & $(3.25 \pm 0.11) \times 10^{-3}$ \\
1-13A1U2 & 57 & 6.01 & $(3.29 \pm 0.13) \times 10^{-3}$ \\
1-14A1U2 & 64 & 6.06 & $(3.39 \pm 0.12) \times 10^{-3}$ \\
1-15A1U2 & 71 & 6.13 & $(3.24 \pm 0.12) \times 10^{-3}$ \\
1-16A1U2 & 79 & 5.92 & $(2.05 \pm 0.08) \times 10^{-3}$ \\
1-17A1U2 & 86 & 6.12 & $(1.66 \pm 0.07) \times 10^{-3}$ \\
\hline & & & \\
\hline
\end{tabular}

average 1-1A1U2 through 1-17A1U2

$(2.88 \pm 0.63) \times 10^{-3}$ 


\section{Appendix IIA. Results of Neptunium solubility experiments in UE-}

25p \#1 water at $25^{\circ} \mathrm{C}$ and $\mathrm{pH} 7.0$

\begin{tabular}{|c|c|c|c|}
\hline Sample I.D. & Days & $\mathrm{pH}$ & Concentration (M) \\
\hline Initial amount added & 0 & - & $1.5 \times 10^{-3}$ \\
\hline 2-1A1U2 & 1 & 7.02 & $(1.99 \pm 0.08) \times 10^{-4}$ \\
\hline 2-2A1U2 & 4 & 7.04 & $(1.51 \pm 0.04) \times 10^{-4}$ \\
\hline 2-3A1U2 & 9 &..- & $(1.47 \pm 0.04) \times 10^{-4}$ \\
\hline 2-4A1U2 & 11 & 7.11 & $(1.49 \pm 0.04) \times 10^{-4}$ \\
\hline $2-5 \mathrm{~A} 1 \mathrm{U} 2$ & 15 & 7.03 & $(1.44 \pm 0.04) \times 10^{-4}$ \\
\hline 2-6A1U2 & 18 & 7.00 & $(1.06 \pm 0.03) \times 10^{-4}$ \\
\hline 2-7A1U2 & 22 & 6.93 & $(8.90 \pm 0.31) \times 10^{-5}$ \\
\hline 2-8A1U2 & 25 & 6.99 & $(9.04 \pm 0.31) \times 10^{-5}$ \\
\hline 2-9A1U2 & 29 & 7.02 & $(8.19 \pm 0.21) \times 10^{-5}$ \\
\hline $2-10 A 2 U 2$ & 36 & 7.09 & $(7.13 \pm 0.27) \times 10^{-5}$ \\
\hline 2-11A1U2 & 43 & 7.13 & $(8.30 \pm 0.30) \times 10^{-5}$ \\
\hline $2-12 \mathrm{~A} 2 \mathrm{U} 2$ & 50 & 6.82 & $(1.07 \pm 0.04) \times 10^{-4}$ \\
\hline 2-13A1U2 & 57 & 7.12 & $(5.47 \pm 0.20) \times 10^{-5}$ \\
\hline $2-14 \mathrm{~A} 1 \mathrm{U} 2$ & 64 & 7.09 & $(3.79 \pm 0.14) \times 10^{-5}$ \\
\hline $2-15 \mathrm{~A} 1 \mathrm{U} 2$ & 71 & 7.15 & $(3.49 \pm 0.12) \times 10^{-5}$ \\
\hline 2-16A1U2 & 79 & 6.95 & $(6.30 \pm 0.23) \times 10^{-5}$ \\
\hline 2-17A1U2 & 86 & 7.12 & $(4.12 \pm 0.16) \times 10^{-5}$ \\
\hline 2-18A1U2 & 94 & 7.10 & $(2.94 \pm 0.13) \times 10^{-5}$ \\
\hline 2-19A1U2 & 98 & 7.16 & $(5.11 \pm 0.21) \times 10^{-5}$ \\
\hline 2-22A1U2 & 106 & 6.85 & $(5.41 \pm 0.22) \times 10^{-5}$ \\
\hline
\end{tabular}


Appendix IIIA. Results of Neptunium solubility experiments in UE25p \#1 water at $25^{\circ} \mathrm{C}$ and $\mathrm{pH} 8.5$

\begin{tabular}{|c|c|c|c|}
\hline Sample I.D. & Days & $\mathrm{pH}$ & Concentration (M) \\
\hline Initial amount added & 0 & - & $1.4 \times 10^{-3}$ \\
\hline 3-1A1U2 & 1 & 8.52 & $(1.08 \pm 0.05) \times 10^{-4}$ \\
\hline 3-2A1U2 & 4 & 8.47 & $(9.62 \pm 0.26) \times 10^{-5}$ \\
\hline 3-3A1U2 & 9 & $\because--$ & $(8.93 \pm 0.25) \times 10^{-5}$ \\
\hline $3-4 \mathrm{~A} 1 \mathrm{U} 2$ & 11 & 8.45 & $(8.65 \pm 0.24) \times 10^{-5}$ \\
\hline 3-5A1U2 & 15 & 8.42 & $(7.81 \pm 0.22) \times 10^{-5}$ \\
\hline $3-6 \mathrm{~A} 1 \mathrm{U} 2$ & 18 & 8.54 & $(7.59 \pm 0.21) \times 10^{-5}$ \\
\hline 3-7A1U2 & 22 & 8.49 & $(6.91 \pm 0.26) \times 10^{-5}$ \\
\hline 3-8A1U2 & 25 & 8.37 & $(6.84 \pm 0.23) \times 10^{-5}$ \\
\hline 3-9A1U2 & 29 & 8.43 & $(6.06 \pm 0.23) \times 10^{-5}$ \\
\hline $3-10 A 2 U 2$ & 36 & 8.56 & $(4.96 \pm 0.18) \times 10^{-5}$ \\
\hline 3-11A1U2 & 43 & 8.38 & $(4.22 \pm 0.12) \times 10^{-5}$ \\
\hline $3-12 A 2 U 2$ & 50 & 8.39 & $(4.22 \pm 0.12) \times 10^{-5}$ \\
\hline 3-13A1U2 & 57 & 8.25 & $(3.42 \pm 0.12) \times 10^{-5}$ \\
\hline $3-14 A 1 U 2$ & 64 & 8.42 & $(2.59 \pm 0.08) \times 10^{-5}$ \\
\hline 3-15A1U2 & 71 & 8.50 & $(1.78 \pm 0.05) \times 10^{-5}$ \\
\hline 3-16A1U2 & 79 & 8.52 & $(6.10 \pm 0.23) \times 10^{-6}$ \\
\hline 3-17A1U2 & 86 & 8.51 & $(6.79 \pm 0.24) \times 10^{-6}$ \\
\hline 3-18A1U2 & 94 & 8.66 & $(8.09 \pm 0.34) \times 10^{-6}$ \\
\hline 3-19A1U2 & 98 & 8.56 & $(7.15 \pm 0.31) \times 10^{-6}$ \\
\hline 3-22A1U2 & 106 & 8.44 & $(6.84 \pm 0.30) \times 10^{-6}$ \\
\hline
\end{tabular}


Appendix IVA. Results of Neptunium solubility experiments in UE25p \#1 water at $60^{\circ} \mathrm{C}$ and $\mathrm{pH} 6.0$

\begin{tabular}{lcll}
\multicolumn{1}{c}{ Sample I.D. } & Days & $\mathrm{pH}$ & Concentration $(\mathrm{M})$ \\
\hline Initial amount added & 0 & - & $(5.6 \pm 0.2) \times 10^{-3}$ \\
1-1 A6U6 & 1 & 6.04 & $(2.32 \pm 0.11) \times 10^{-3}$ \\
1-2A2U6 & 10 & 5.98 & $(2.62 \pm 0.11) \times 10^{-3}$ \\
1-3A2U6 & 16 & 6.07 & $(2.67 \pm 0.12) \times 10^{-3}$ \\
1-4A1U6 & 31 & 6.04 & $(2.60 \pm 0.11) \times 10^{-3}$ \\
1-5A1U6 & 43 & 6.02 & $(2.65 \pm 0.09) \times 10^{-3}$ \\
1-6A1U6 & 59 & 5.99 & $(2.59 \pm 0.10) \times 10^{-3}$ \\
1-7A2U6 & 87 & 6.02 & $(2.61 \pm 0.10) \times 10^{-3}$ \\
1-8A1U6 & 101 & 6.02 & $(2.27 \pm 0.09) \times 10^{-3}$ \\
1-9A1U6 & 111 & 5.97 & $(2.43 \pm 0.09) \times 10^{-3}$ \\
1-10A1U6 & 143 & 6.04 & $(2.22 \pm 0.07) \times 10^{-3}$ \\
1-11A1U6 & 170 & 6.01 & $(2.28 \pm 0.08) \times 10^{-3}$ \\
& & & \\
\hline
\end{tabular}

average 1-1 A6U6 through 1-11A1U6

$(2.48 \pm 0.18) \times 10^{-3}$ 
Appendix VA. Results of Neptunium solubility experiments in UE$25 \mathrm{p} \# 1$ water at $60^{\circ} \mathrm{C}$ and $\mathrm{pH} 7.0$

\begin{tabular}{lcll}
\multicolumn{1}{c}{ Sample I.D. } & Days & $\mathrm{pH}$ & Concentration $(\mathrm{M})$ \\
\hline Initial amount added & 0 & - & $(1.5 \pm 0.1) \times 10^{-3}$ \\
2-1A6U6 & 1 & 7.02 & $(6.66 \pm 0.22) \times 10^{-5}$ \\
2-2A2U6 & 10 & 6.96 & $(3.35 \pm 0.12) \times 10^{-5}$ \\
2-3A2U6 & 16 & 7.09 & $(2.98 \pm 0.11) \times 10^{-5}$ \\
2-4A1U6 & 31 & 7.10 & $(2.90 \pm 0.12) \times 10^{-5}$ \\
2-5A1U6 & 43 & 7.10 & $(3.09 \pm 0.11) \times 10^{-5}$ \\
2-6A1U6 & 59 & 6.88 & $(3.62 \pm 0.14) \times 10^{-5}$ \\
2-7A2U6 & 87 & 7.09 & $(3.54 \pm 0.16) \times 10^{-5}$ \\
2-8A1U6 & 101 & 7.03 & $(2.26 \pm 0.14) \times 10^{-5}$ \\
2-9A1U6 & 111 & 6.97 & $(5.07 \pm 0.22) \times 10^{-5}$ \\
2-10A1U6 & 143 & 7.07 & $(2.79 \pm 0.09) \times 10^{-5}$ \\
2-11A1U6 & 170 & 7.07 & $(5.14 \pm 0.28) \times 10^{-5}$ \\
2-12A1U6 & 183 & 7.06 & $(2.11 \pm 0.11) \times 10^{-5}$ \\
& & & \\
\hline
\end{tabular}

average 2-2A2U6 through 2-12A1U6

$(3.35 \pm 0.99) \times 10^{-5}$ 
Appendix VIA. Results of Neptunium solubility experiments in UE$25 \mathrm{p}$ \#1 water at $60^{\circ} \mathrm{C}$ and $\mathrm{pH} 8.5$

\begin{tabular}{lcll}
\multicolumn{1}{c}{ Sample I.D. } & Days & $\mathrm{pH}$ & Concentration $(\mathrm{M})$ \\
\hline Initial amount added & 0 & - & $(1.5 \pm 0.1) \times 10^{-3}$ \\
3-1 A6U6 & 1 & 8.45 & $(9.22 \pm 0.44) \times 10^{-6}$ \\
3-2A2U6 & 10 & 8.34 & $(8.43 \pm 0.31) \times 10^{-6}$ \\
3-3A2U6 & 16 & 8.31 & $(8.43 \pm 0.34) \times 10^{-6}$ \\
3-4A1U6 & 31 & 8.32 & $(9.17 \pm 0.39) \times 10^{-6}$ \\
3-5A1U6 & 43 & 8.54 & $(1.15 \pm 0.05) \times 10^{-5}$ \\
3-6A1U6 & 59 & 8.40 & $(1.23 \pm 0.06) \times 10^{-5}$ \\
3-7A6U6 & 87 & 8.50 & $(1.26 \pm 0.06) \times 10^{-5}$ \\
3-8A1U6 & 101 & 8.50 & $(1.55 \pm 0.09) \times 10^{-5}$ \\
3-9A1U6 & 111 & 8.37 & $(1.50 \pm 0.09) \times 10^{-5}$ \\
3-10A1U6 & 143 & 8.45 & $(2.35 \pm 0.13) \times 10^{-5}$ \\
3-11A1U6 & 155 & 8.50 & $(2.68 \pm 0.09) \times 10^{-5}$ \\
& & & \\
\hline assay 3-11A1U6 & & & $(2.68 \pm 0.09) \times 10^{-5}$
\end{tabular}




\section{APPENDIX B}

\section{RESULTS OF PLUTONIUM SOLUBILITY EXPERIMENTS}

IN UE-25p \#1 WATER 
Appendix IB. Results of Plutonium solubility experiments in UE-25p \#1 water at $25^{\circ} \mathrm{C}$ and $\mathrm{pH} 6.0$

\begin{tabular}{|c|c|c|c|}
\hline Sample I.D. & Days & $\mathrm{pH}$ & Concentration (M) \\
\hline Initial amount added & 0 & - & $3.8 \times 10^{-4}$ \\
\hline 4-1A1U2 & 1 & 6.09 & $(7.40 \pm 0.37) \times 10^{-10}$ \\
\hline $4-2 \mathrm{~A} 1 \mathrm{U} 2$ & 5 & 6.08 & $(3.51 \pm 0.31) \times 10^{-7}$ \\
\hline 4-3A1U2 & 8 & 5.95 & $(8.49 \pm 0.72) \times 10^{-7}$ \\
\hline $4-4 \mathrm{~A} 1 \mathrm{U} 2$ & 12 & 5.90 & $(1.51 \pm 0.13) \times 10^{-6}$ \\
\hline 4-5A1U2 & 19 & 5.99 & $(1.98 \pm 0.17) \times 10^{-6}$ \\
\hline 4-6A1U2 & 26 & 5.89 & $(1.76 \pm 0.15) \times 10^{-6}$ \\
\hline 4-7A1U2 & 33 & 5.91 & $(1.52 \pm 0.13) \times 10^{-6}$ \\
\hline $4-8 \mathrm{~A} 1 \mathrm{U} 2$ & 40 & 5.91 & $(1.34 \pm 0.11) \times 10^{-6}$ \\
\hline $4-9 \mathrm{~A} 2 \mathrm{U} 2$ & 48 & 6.06 & $(1.20 \pm 0.10) \times 10^{-6}$ \\
\hline 4-10A1U2 & 55 & 5.97 & $(1.12 \pm 0.10) \times 10^{-6}$ \\
\hline 4-11A1U2 & 63 & 5.92 & $(1.06 \pm 0.09) \times 10^{-6}$ \\
\hline 4-13A1U2 & 75 & 5.97 & $(8.03 \pm 0.68) \times 10^{-7}$ \\
\hline $4-14 \mathrm{~A} 1 \mathrm{U} 2$ & 82 & 5.96 & $(8.68 \pm 0.79) \times 10^{-7}$ \\
\hline 4-16A1U2 & 90 & 6.04 & $(8.34 \pm 0.73) \times 10^{-7}$ \\
\hline 4-17A1U2 & 96 & 6.09 & $(8.67 \pm 0.71) \times 10^{-7}$ \\
\hline 4-18A1U2 & 103 & 6.07 & $(8.43 \pm 0.72) \times 10^{-7}$ \\
\hline 4-19A1U2 & 109 & 6.10 & $(8.00 \pm 0.82) \times 10^{-7}$ \\
\hline 4-20A1U2 & 118 & 6.01 & $(7.79 \pm 0.80) \times 10^{-7}$ \\
\hline
\end{tabular}

average 4-13A1U2 through 4-20A1U2

$(8.28 \pm 0.35) \times 10^{-7}$ 


\section{Appendix IIB. Results of Plutonium solubility experiments in UE- 25p \#1 water at $25^{\circ} \mathrm{C}$ and $\mathrm{pH} 7.0$}

\begin{tabular}{lccc}
\multicolumn{1}{c}{ Sample I.D. } & Days & $\mathrm{pH}$ & Concentration $(\mathrm{M})$ \\
\hline Initial amount added & 0 & - & $3.8 \times 10^{-4}$ \\
5-1A1U2 & 1 & 7.14 & $(1.49 \pm 0.34) \times 10^{-8}$ \\
5-2A1U2 & 5 & 7.06 & $(2.29 \pm 0.31) \times 10^{-7}$ \\
5-3A1U2 & 8 & 7.02 & $(4.04 \pm 0.36) \times 10^{-7}$ \\
5-4A1U2 & 12 & 7.08 & $(4.47 \pm 0.39) \times 10^{-7}$ \\
5-5A1U2 & 19 & 7.10 & $(5.85 \pm 0.50) \times 10^{-7}$ \\
5-6A1U2 & 26 & 6.92 & $(6.00 \pm 0.51) \times 10^{-7}$ \\
5-7A1U2 & 33 & 7.10 & $(5.72 \pm 0.50) \times 10^{-7}$ \\
5-8A1U2 & 40 & 7.12 & $(5.75 \pm 0.49) \times 10^{-7}$ \\
5-9A2U2 & 48 & 7.14 & $(4.79 \pm 0.43) \times 10^{-7}$ \\
5-10A1U2 & 55 & 7.13 & $(4.37 \pm 0.38) \times 10^{-7}$ \\
5-11A1U2 & 63 & 7.05 & $(3.66 \pm 0.31) \times 10^{-7}$ \\
5-12A1U2 & 67 & 7.06 & $(5.05 \pm 0.52) \times 10^{-7}$ \\
5-13A1U2 & 75 & 6.96 & $(4.12 \pm 0.36) \times 10^{-7}$ \\
5-14A1U2 & 82 & 7.11 & $(4.52 \pm 0.39) \times 10^{-7}$ \\
5-16A1U2 & 90 & 6.98 & $(4.51 \pm 0.47) \times 10^{-7}$ \\
5-17A1U2 & 96 & 7.11 & $(4.97 \pm 0.45) \times 10^{-7}$ \\
5-18A1U2 & 103 & 6.91 & $(4.82 \pm 0.53) \times 10^{-7}$ \\
5-19A1U2 & 109 & 7.00 & $(4.65 \pm 0.48) \times 10^{-7}$ \\
5-20A1U2 & 118 & 6.88 & $(4.01 \pm 0.39) \times 10^{-7}$ \\
5-21A1U2 & 126 & 7.21 & $(4.08 \pm 0.47) \times 10^{-7}$ \\
\hline average 5-13A1U2 through 5-21A1U2 & & $(4.46 \pm 0.36) \times 10^{-7}$
\end{tabular}


Appendix IIIB. Results of Plutonium solubility experiments in UE25p \#1 water at $25^{\circ} \mathrm{C}$ and pH 8.5

\begin{tabular}{lclc}
\multicolumn{1}{c}{ Sample I.D. } & Days & $\mathrm{pH}$ & Concentration $(\mathrm{M})$ \\
\hline Initial amount added & 0 & - & $3.8 \times 10^{-4}$ \\
6-1A1U2 & 1 & 8.55 & $(1.39 \pm 0.15) \times 10^{-7}$ \\
6-2A1U2 & 5 & 8.55 & $(3.35 \pm 0.31) \times 10^{-7}$ \\
6-3A1U2 & 8 & 8.58 & $(5.02 \pm 0.45) \times 10^{-7}$ \\
6-4A1U2 & 12 & 8.57 & $(6.30 \pm 0.55) \times 10^{-7}$ \\
6-5A1U2 & 19 & 8.47 & $(6.52 \pm 0.54) \times 10^{-7}$ \\
6-6A1U2 & 26 & 8.44 & $(8.30 \pm 0.71) \times 10^{-7}$ \\
6-7A1U2 & 33 & 8.54 & $(8.60 \pm 0.74) \times 10^{-7}$ \\
6-8A1U2 & 40 & 8.41 & $(9.56 \pm 0.82) \times 10^{-7}$ \\
6-9A2U2 & 48 & 8.52 & $(1.00 \pm 0.09) \times 10^{-6}$ \\
6-10A1U2 & 55 & 8.42 & $(1.01 \pm 0.09) \times 10^{-6}$ \\
6-11A1U2 & 63 & 8.52 & $(9.50 \pm 1.03) \times 10^{-7}$ \\
6-12A1U2 & 67 & 8.51 & $(9.68 \pm 1.03) \times 10^{-7}$ \\
6-13A1U2 & 75 & 8.47 & $(7.01 \pm 0.62) \times 10^{-7}$ \\
6-14A1U2 & 82 & 8.53 & $(1.16 \pm 0.10) \times 10^{-6}$ \\
6-16A1U2 & 90 & 8.43 & $(1.10 \pm 0.09) \times 10^{-6}$ \\
6-17A1U2 & 96 & 8.48 & $(8.85 \pm 0.80) \times 10^{-7}$ \\
6-18A1U2 & 103 & 8.40 & $(1.17 \pm 0.10) \times 10^{-6}$ \\
6-19A1U2 & 109 & 8.39 & $(1.23 \pm 0.13) \times 10^{-6}$ \\
\hline & & & \\
\hline
\end{tabular}

average 6-8A1U2 through 6-19A1U2

$(1.01 \pm 0.14) \times 10^{-6}$ 
Appendix IVB. Results of Plutonium solubility experiments in UE$25 p$ \#1 water at $60^{\circ} \mathrm{C}$ and $\mathrm{pH} 6.0$

\begin{tabular}{lcll}
\multicolumn{1}{c}{ Sample I.D. } & Days & $\mathrm{pH}$ & Concentration $(\mathrm{M})$ \\
\hline Initial amount added & 0 & - & $(2.2 \pm 0.2) \times 10^{-4}$ \\
4-1A6U6 & 1 & 5.87 & $(6.65 \pm 0.76) \times 10^{-9}$ \\
4-2A1U6 & 6 & 5.85 & $(2.18 \pm 0.14) \times 10^{-7}$ \\
4-3A1U6 & 9 & 5.67 & $(6.64 \pm 0.42) \times 10^{-7}$ \\
4-4A1U6 & 21 & 6.04 & $(1.41 \pm 0.09) \times 10^{-6}$ \\
4-5A1U6 & 37 & 5.96 & $(1.90 \pm 0.12) \times 10^{-6}$ \\
4-6A2U6 & 65 & 5.90 & $(8.97 \pm 0.56) \times 10^{-7}$ \\
4-7A1U6 & 79 & 6.90 & $(9.04 \pm 0.57) \times 10^{-7}$ \\
4-8A1U6 & 121 & 6.04 & $(7.11 \pm 0.45) \times 10^{-7}$ \\
4-9A1U6 & 176 & 6.16 & $(2.59 \pm 0.22) \times 10^{-7}$ \\
4-10A1U6 & 236 & 6.08 & $(7.22 \pm 0.63) \times 10^{-8}$ \\
4-11A1U6 & 258 & 5.90 & $(9.42 \pm 0.84) \times 10^{-8}$ \\
4-12A1U6 & 286 & 5.93 & $(9.91 \pm 0.89) \times 10^{-8}$ \\
& & & \\
\hline
\end{tabular}

average 4-10A1U6 through 4-12A1U6

$(8.85 \pm 1.43) \times 10^{-8}$ 
Appendix VB. Results of Plutonium solubility experiments in UE$25 \mathrm{p} \# 1$ water at $60^{\circ} \mathrm{C}$ and $\mathrm{pH} 7.0$

\begin{tabular}{lcll}
\multicolumn{1}{c}{ Sample I.D. } & Days & $\mathrm{pH}$ & Concentration $(\mathrm{M})$ \\
\hline Initial amount added & 0 & - & $(2.2 \pm 0.2) \times 10^{-4}$ \\
5-1A6U6 & 1 & 7.33 & $(5.13 \pm 0.37) \times 10^{-8}$ \\
5-2A1U6 & 6 & 7.29 & $(1.96 \pm 0.12) \times 10^{-7}$ \\
5-3A1U6 & 9 & 7.35 & $(2.62 \pm 0.14) \times 10^{-7}$ \\
5-4A1U6 & 21 & 7.29 & $(3.45 \pm 0.22) \times 10^{-7}$ \\
5-5A1U6 & 37 & 7.31 & $(4.39 \pm 0.28) \times 10^{-7}$ \\
5-6A2U6 & 65 & 7.41 & $(2.88 \pm 0.18) \times 10^{-7}$ \\
5-7A1U6 & 79 & 7.64 & $(2.43 \pm 0.15) \times 10^{-7}$ \\
5-8A1U6 & 121 & 7.01 & $(2.26 \pm 0.14) \times 10^{-7}$ \\
5-9A1U6 & 176 & 7.25 & $(9.32 \pm 0.80) \times 10^{-8}$ \\
5-10A1U6 & 236 & 7.36 & $(8.13 \pm 0.71) \times 10^{-8}$ \\
5-11A1U6 & 274 & 6.88 & $(1.07 \pm 0.10) \times 10^{-7}$ \\
5-12A1U6 & 287 & 7.09 & $(8.07 \pm 0.73) \times 10^{-8}$ \\
& & & \\
\hline
\end{tabular}

average 5-9A1U6 through 5-12A1U6

$(9.06 \pm 1.24) \times 10^{-8}$ 


\section{Appendix VIB. Results of Plutonium solubility experiments in UE- 25p \#1 water at $60^{\circ} \mathrm{C}$ and $\mathrm{pH} 8.5$}

\begin{tabular}{lcll}
\multicolumn{1}{c}{ Sample I.D. } & Days & $\mathrm{pH}$ & Concentration $(\mathrm{M})$ \\
\hline Initial amount added & 0 & - & $(2.0 \pm 0.2) \times 10^{-4}$ \\
6-1A6U6 & 1 & 7.90 & $(3.40 \pm 0.22) \times 10^{-7}$ \\
6-2A1U6 & 6 & 7.98 & $(3.89 \pm 0.24) \times 10^{-7}$ \\
6-3A1U6 & 9 & 8.23 & $(4.01 \pm 0.25) \times 10^{-7}$ \\
6-4A1U6 & 21 & 8.54 & $(4.21 \pm 0.26) \times 10^{-7}$ \\
6-5A1U6 & 37 & 8.04 & $(4.84 \pm 0.30) \times 10^{-7}$ \\
6-6A2U6 & 65 & 8.49 & $(5.45 \pm 0.34) \times 10^{-7}$ \\
6-7A1U6 & 79 & 8.42 & $(8.59 \pm 0.54) \times 10^{-7}$ \\
6-8A1U6 & 121 & 8.44 & $(2.57 \pm 0.16) \times 10^{-7}$ \\
6-9A1U6 & 176 & 8.58 & $(2.02 \pm 0.17) \times 10^{-6}$ \\
6-10A1U6 & 236 & 8.51 & $(1.42 \pm 0.12) \times 10^{-6}$ \\
6-11A1U6 & 279 & 8.50 & $(7.00 \pm 0.63) \times 10^{-7}$ \\
6-12A1U6 & 294 & 8.43 & $(7.15 \pm 0.64) \times 10^{-7}$ \\
& & & \\
\hline
\end{tabular}

average 6-6A2U6 through 6-12A1U6

$(9.31 \pm 5.96) \times 10^{-7}$ 


\section{APPENDIX C}

RESULTS OF AMERICIUM/NEODYMIUM SOLUBILITY EXPERIMENTS IN UE-25p \#1 WATER 


\section{Appendix IC. Results of Americium/Neodymium solubility experiments in UE-25p \#1 water at $25^{\circ} \mathrm{C}$ and pH 6.0}

\begin{tabular}{lclc}
\multicolumn{1}{c}{ Sample I.D. } & Days & $\mathrm{pH}$ & Concentration $(\mathrm{M})$ \\
\hline Initial amount added & 0 & - & $1.9 \times 10^{-4}$ \\
7-1A2U2 & 1 & 5.85 & $(1.05 \pm 0.05) \times 10^{-4}$ \\
7-2A2U2 & 5 & 5.91 & $(2.18 \pm 0.11) \times 10^{-5}$ \\
7-3A2U2 & 8 & 6.07 & $(3.53 \pm 0.16) \times 10^{-5}$ \\
7-4A2U2 & 12 & 6.10 & $(6.41 \pm 0.29) \times 10^{-5}$ \\
7-5A1U2 & 19 & 6.30 & $(1.51 \pm 0.07) \times 10^{-4}$ \\
7-6A2U2 & 22 & 5.61 & $(1.85 \pm 0.08) \times 10^{-4}$ \\
7-7A1U2 & 26 & 5.97 & $(9.52 \pm 0.46) \times 10^{-6}$ \\
7-8A1U2 & 29 & 6.03 & $(6.24 \pm 0.29) \times 10^{-6}$ \\
7-9A1U2 & 33 & 6.10 & $(5.94 \pm 0.29) \times 10^{-7}$ \\
7-10A1U2 & 36 & 5.97 & $(3.98 \pm 0.19) \times 10^{-7}$ \\
7-11A1U2 & 40 & 5.86 & $(3.28 \pm 0.16) \times 10^{-7}$ \\
7-12A1U2 & 47 & 6.02 & $(3.11 \pm 0.15) \times 10^{-7}$ \\
7-13A1U2 & 54 & 6.13 & $(2.48 \pm 0.12) \times 10^{-7}$ \\
7-14A1U2 & 62 & 6.10 & $(2.03 \pm 0.10) \times 10^{-7}$ \\
7-15A1U2 & 69 & 6.01 & $(3.52 \pm 0.24) \times 10^{-7}$ \\
7-16A2U2 & 71 & 6.11 & $(2.32 \pm 0.46) \times 10^{-7}$ \\
7-17A1U2 & 77 & 5.95 & $(4.93 \pm 0.99) \times 10^{-7}$ \\
7-18A2U2 & 81 & 6.01 & $(3.44 \pm 0.69) \times 10^{-7}$ \\
7-19A1U2 & 89 & 6.10 & $(3.20 \pm 0.64) \times 10^{-7}$ \\
7-20A1U2 & 96 & 6.04 & $(3.52 \pm 0.70) \times 10^{-7}$ \\
7-21A1U2 & 104 & 5.93 & $(3.07 \pm 0.61) \times 10^{-7}$ \\
7-22A2U2 & 110 & 6.03 & $(1.40 \pm 0.28) \times 10^{-7}$ \\
\hline & & & \\
average 7-16A2U2 through 7-22A2U2 & $(3.13 \pm 1.09) \times 10^{-7}$ \\
& & & \\
& & &
\end{tabular}




\section{Appendix IIC. Results of Americium/Neodymium solubility experiments in UE-25p \#1 water at $25^{\circ} \mathrm{C}$ and $\mathrm{pH} 7.0$}

\begin{tabular}{lccc}
\multicolumn{1}{c}{ Sample I.D. } & Days & $\mathrm{pH}$ & Concentration $(\mathrm{M})$ \\
\hline Initial amount added & 0 & - & $1.9 \times 10^{-4}$ \\
8-1A2U2 & 1 & 7.10 & $(1.12 \pm 0.05) \times 10^{-6}$ \\
8-2A2U2 & 5 & 7.06 & $(1.07 \pm 0.05) \times 10^{-6}$ \\
8-3A2U2 & 8 & 7.10 & $(1.06 \pm 0.05) \times 10^{-6}$ \\
8-4A2U2 & 12 & 7.09 & $(1.10 \pm 0.06) \times 10^{-6}$ \\
8-5A1U2 & 19 & 7.13 & $(1.70 \pm 0.08) \times 10^{-6}$ \\
8-6A2U2 & 22 & 7.05 & $(4.48 \pm 0.21) \times 10^{-6}$ \\
8-7A1U2 & 26 & 7.08 & $(2.57 \pm 0.13) \times 10^{-6}$ \\
8-8A1U2 & 29 & 7.08 & $(2.40 \pm 0.12) \times 10^{-6}$ \\
8-9A1U2 & 33 & 6.94 & $(5.13 \pm 0.24) \times 10^{-6}$ \\
8-10A1U2 & 36 & 7.05 & $(2.72 \pm 0.13) \times 10^{-6}$ \\
8-11A1U2 & 40 & 6.92 & $(1.73 \pm 0.08) \times 10^{-6}$ \\
8-12A1U2 & 47 & 7.07 & $(1.67 \pm 0.08) \times 10^{-6}$ \\
8-13A1U2 & 54 & 6.92 & $(8.32 \pm 0.41) \times 10^{-7}$ \\
8-14A1U2 & 62 & 7.07 & $(3.13 \pm 0.16) \times 10^{-7}$ \\
8-15A1U2 & 69 & 7.05 & $(2.26 \pm 0.16) \times 10^{-7}$ \\
8-16A2U2 & 71 & 7.11 & $(2.66 \pm 0.40) \times 10^{-7}$ \\
8-17A1U2 & 77 & 7.31 & $(3.78 \pm 0.57) \times 10^{-7}$ \\
8-18A2U2 & 81 & 7.12 & $(1.14 \pm 0.17) \times 10^{-7}$ \\
8-19A1U2 & 89 & 7.11 & $(1.80 \pm 0.27) \times 10^{-7}$ \\
8-20A1U2 & 96 & 7.09 & $(1.40 \pm 0.21) \times 10^{-7}$ \\
8-21A1U2 & 104 & 7.04 & $(4.96 \pm 0.74) \times 10^{-7}$ \\
8-22A2U2 & 110 & 7.09 & $(4.65 \pm 0.70) \times 10^{-7}$ \\
8-23A2U2 & 117 & 7.19 & $(3.54 \pm 0.53) \times 10^{-7}$ \\
8-24A1U2 & 123 & 7.06 & $(5.22 \pm 0.78) \times 10^{-7}$ \\
\hline & & & \\
average 8-16A2U2 through 8-24A1U2 & $(3.24 \pm 1.56) \times 10^{-7}$
\end{tabular}




\section{Appendix IIIC. Results of Americium/Neodymium solubility experiments in UE-25p \#1 water at $25^{\circ} \mathrm{C}$ and $\mathrm{pH} 8.5$}

\begin{tabular}{|c|c|c|c|}
\hline Sample I.D. & Days & $\mathrm{pH}$ & Concentration (M) \\
\hline Initial amount added & 0 & - & $1.9 \times 10^{-4}$ \\
\hline $9-1 \mathrm{~A} 2 \mathrm{U} 2$ & 1 & 8.52 & $(9.12 \pm 0.40) \times 10^{-6}$ \\
\hline $9-2 \mathrm{~A} 2 \mathrm{U} 2$ & 5 & 8.57 & $(7.38 \pm 0.34) \times 10^{-6}$ \\
\hline $9-3 \mathrm{~A} 2 \mathrm{U} 2$ & 8 & 8.51 & $(6.84 \pm 0.34) \times 10^{-6}$ \\
\hline $9-4 \mathrm{~A} 2 \mathrm{U} 2$ & 12 & 8.50 & $(6.88 \pm 0.32) \times 10^{-6}$ \\
\hline $9-5 \mathrm{~A} 2 \mathrm{U} 2$ & 19 & 8.47 & $(7.51 \pm 0.36) \times 10^{-6}$ \\
\hline 9-6A1U2 & 22 & 8.37 & $(8.45 \pm 0.40) \times 10^{-6}$ \\
\hline $9.7 \mathrm{~A} 1 \mathrm{U} 2$ & 26 & 8.42 & $(9.57 \pm 0.46) \times 10^{-6}$ \\
\hline $9-8 \mathrm{~A} 1 \mathrm{U} 2$ & 29 & 8.59 & $(9.22 \pm 0.42) \times 10^{-6}$ \\
\hline 9-9A1U2 & 33 & 8.54 & $(9.44 \pm 0.43) \times 10^{-6}$ \\
\hline $9-10 \mathrm{~A} 1 \mathrm{U} 2$ & 36 & 8.58 & $(9.24 \pm 0.46) \times 10^{-6}$ \\
\hline $9-11 \mathrm{~A} 1 \mathrm{U} 2$ & 40 & 8.32 & $(9.17 \pm 0.42) \times 10^{-6}$ \\
\hline $9-12 \mathrm{~A} 1 \mathrm{U} 2$ & 47 & 8.48 & $(6.30 \pm 0.29) \times 10^{-6}$ \\
\hline $9-13 \mathrm{~A} 1 \mathrm{U} 2$ & 54 & 8.54 & $(4.82 \pm 0.24) \times 10^{-6}$ \\
\hline $9-14 \mathrm{~A} 1 \mathrm{U} 2$ & 62 & 8.63 & $(3.96 \pm 0.19) \times 10^{-6}$ \\
\hline $9-15 \mathrm{~A} 1 \mathrm{U} 2$ & 69 & 8.51 & $(3.97 \pm 0.27) \times 10^{-6}$ \\
\hline 9-17A1U2 & 77 & 8.61 & $(3.16 \pm 0.22) \times 10^{-6}$ \\
\hline 9-19A1U2 & 89 & 8.74 & $(2.58 \pm 0.12) \times 10^{-6}$ \\
\hline $9-20 \mathrm{~A} 1 \mathrm{U} 2$ & 96 & 8.37 & $(2.87 \pm 0.14) \times 10^{-6}$ \\
\hline $9-21 \mathrm{~A} 1 \mathrm{U} 2$ & 104 & 8.41 & $(2.06 \pm 0.15) \times 10^{-6}$ \\
\hline
\end{tabular}

average 9-14A1U2 through 9-21A1U2

$(3.10 \pm 0.76) \times 10^{-6}$ 


\section{Appendix IVC. Results of Americium/Neodymium solubility experiments in UE-25p \#1 water at $60^{\circ} \mathrm{C}$ and $\mathrm{pH} 6.0$}

\begin{tabular}{lcll}
\multicolumn{1}{c}{ Sample I.D. } & Days & $\mathrm{pH}$ & Concentration $(\mathrm{M})$ \\
\hline Initial amount added & 0 & - & $(2.3 \pm 0.1) \times 10^{-4}$ \\
7-1A6U6 & 1 & 6.05 & $(3.18 \pm 0.19) \times 10^{-6}$ \\
7-2A1U6 & 9 & 5.99 & $(1.33 \pm 0.07) \times 10^{-7}$ \\
7-3A1U6 & 16 & 5.89 & $(1.30 \pm 0.07) \times 10^{-7}$ \\
7-4A1U6 & 28 & 6.01 & $(4.20 \pm 0.23) \times 10^{-8}$ \\
7-5A1U6 & 44 & 6.00 & $(5.94 \pm 0.33) \times 10^{-8}$ \\
7-6A6U6 & 72 & 6.05 & $(7.88 \pm 0.64) \times 10^{-9}$ \\
7-7A1U6 & 125 & 6.06 & $(2.37 \pm 0.36) \times 10^{-9}$ \\
7-8A1U6 & 183 & 5.90 & $(2.59 \pm 0.20) \times 10^{-9}$ \\
7-9A1U6 & 244 & 6.57 & $(3.18 \pm 0.40) \times 10^{-9}$ \\
& & & \\
\hline \multicolumn{4}{r}{ average 7-7A1U6 through 7-9A1U6 }
\end{tabular}


Appendix VC. Results of Americium/Neodymium solubility experiments in UE-25p \#1 water at $60^{\circ} \mathrm{C}$ and pH 7.0

\begin{tabular}{lcll}
\multicolumn{1}{c}{ Sample I.D. } & Days & $\mathrm{pH}$ & Concentration $(\mathrm{M})$ \\
\hline Initial amount added & 0 & - & $(2.3 \pm 0.1) \times 10^{-4}$ \\
8-1 A6U6 & 1 & 7.07 & $(7.92 \pm 0.65) \times 10^{-7}$ \\
8-2A1U6 & 9 & 7.06 & $(1.62 \pm 0.09) \times 10^{-8}$ \\
8-3A1U6 & 16 & 7.00 & $(3.80 \pm 0.24) \times 10^{-9}$ \\
8-4A1U6 & 28 & 7.08 & $(2.49 \pm 0.15) \times 10^{-8}$ \\
8-5A1U6 & 44 & 7.02 & $(1.06 \pm 0.30) \times 10^{-9}$ \\
8-6A6U6 & 72 & 7.06 & $(7.46 \pm 1.95) \times 10^{-10}$ \\
8-7A1U6 & 125 & 7.11 & $(6.73 \pm 1.92) \times 10^{-10}$ \\
& & & \\
\hline
\end{tabular}

average 8-6A6U6 through 8-7A1U6

$(7.09 \pm 0.52) \times 10^{-10}$ 


\section{Appendix VIC. Results of Americium/Neodymium solubility experiments in UE-25p \#1 water at $60^{\circ} \mathrm{C}$ and $\mathrm{pH} 8.5$}

\begin{tabular}{lcll}
\multicolumn{1}{c}{ Sample I.D. } & Days & $\mathrm{pH}$ & Concentration $(\mathrm{M})$ \\
\hline Initial amount added & 0 & - & $(2.3 \pm 0.1) \times 10^{-4}$ \\
9-1 A6U6 & 1 & 7.78 & $(2.96 \pm 0.36) \times 10^{-7}$ \\
9-2A1U6 & 9 & 8.38 & $(2.49 \pm 0.13) \times 10^{-7}$ \\
9-3A1U6 & 16 & 8.64 & $(6.66 \pm 0.42) \times 10^{-9}$ \\
9-4A1U6 & 28 & 8.39 & $(1.58 \pm 0.09) \times 10^{-8}$ \\
9-5A1U6 & 44 & 8.42 & $(6.89 \pm 0.59) \times 10^{-9}$ \\
9-6A6U6 & 72 & 8.51 & $(5.19 \pm 0.44) \times 10^{-9}$ \\
9-7A1U6 & 125 & 8.46 & $(1.30 \pm 0.09) \times 10^{-8}$ \\
9-8A1U6 & 183 & 8.53 & $(6.89 \pm 0.52) \times 10^{-9}$ \\
9-9A1U6 & 244 & 8.61 & $(3.41 \pm 0.40) \times 10^{-9}$ \\
9-10A1U6 & 274 & 8.56 & $(2.99 \pm 0.47) \times 10^{-9}$ \\
9-11A1U6 & 308 & 8.54 & $(9.60 \pm 0.71) \times 10^{-9}$ \\
& & & \\
\hline
\end{tabular}

average 9-3A1U6 through 9-11A1U6

$(7.83 \pm 4.28) \times 10^{-9}$ 
The data used to write this report are recorded in the following TMP Laboratory Record Books:

TWS-LBL-05-88-01, pp. 73 - 301

TWS-LBL-01-89-01, pp. 1 - 293

TWS-LBL-01-89-02, pp. 1 - 303

TWS-LBL-07-89-01, pp $1-108$

TWS-LBL-02-90-04, pp. $231-299$

TWS-LBL-10-91-04, pp. 1 - 211

TWS-LBL-01-92-02, pp. 1 - 209

TWS-LBL-01-93-02, pp. 1- 77 (open)

TWS-LBL-01-93-04, pp. 1- 79 (open) 
This report has been reproduced directly from the best available copy.

It is available to DOE and DOE contractors from the Office of Scientific and Technical Information,

P.O. Box 62 ,

Oak Ridge, TN 37831 .

Prices are available from

(615) $576-8401$

It is available to the public from the

National Technical Information Service,

US Department of Commerce,

5285 Port Royal Rd.,

Springfield, VA 22161 . 


\section{Los Alamos \\ NATIONAL LABORATORY \\ Los Alamos, New Mexico 87545}

